UNIVERSIDADE DE SÃO PAULO

FACULDADE DE ECONOMIA, ADMINISTRAÇÃO E CONTABILIDADE DEPARTAMENTO DE CONTABILIDADE E ATUÁRIA

\title{
CONTABILIDADE GERENCIAL: \\ UM ESTUDO SOBRE A CONTRIBUIÇÃO DO BALANCED SCORECARD
}

Ana Paula Paulino da Costa

Orientador: Prof. Dr. Sérgio de Iudícibus 
Reitor da Universidade de São Paulo

Prof. Dr Jacque Marcovitch

Diretor da Faculdade de Economia, Administração e Contabilidade Prof. Dr. Eliseu Martins

Chefe do Departamento de Contabilidade e Atuária

Prof. Dr. Reinaldo Guerreiro 


\section{FICHA CATALOGRÁFICA}

Costa, Ana Paula Paulino da Costa

Contabilidade Gerencial: um estudo sobre a contribuição do Balanced Scorecard / Ana Paula Paulino da Costa. _ São Paulo: FEA/USP, 2001. $164 \mathrm{p}$.

Dissertação - Mestrado

Bibliografia.

1. Contabilidade Gerencial 2. Sistema de Suporte à Decisão 3. Desempenho - Mensuração 4. Gestão Estratégica I. Faculdade de Economia, Administração e Contabilidade da USP. 
UNIVERSIDADE DE SÃO PAULO

FACULDADE DE ECONOMIA, ADMINISTRAÇÃO E CONTABILIDADE DEPARTAMENTO DE CONTABILIDADE E ATUÁRIA

\title{
CONTABILIDADE GERENCIAL: \\ UM ESTUDO SOBRE A CONTRIBUIÇÃO DO BALANCED SCORECARD
}

\author{
Ana Paula Paulino da Costa
}

Dissertação apresentada ao Departamento de Contabilidade e Atuária para o cumprimento das exigências para obtenção do título de Mestre em Controladoria e Contabilidade pela Faculdade de Economia, Administração e Contabilidade da Universidade de São Paulo.

Orientador: Prof. Dr. Sérgio de Iudícibus 
Ao meu marido, Paulo de Tarso, dedico todo esse ciclo de aprendizado. 


\section{A G R A D E C I M E N T OS}

Ao Prof. Dr. Sérgio de Iudícibus, exemplo de ética, de elegância e de comportamento acadêmico, com notório saber em contabilidade, cuja convivência só fez aumentar a minha admiração, por ter permitido que eu me beneficiasse dos seus conhecimentos teóricos. Devo a ele não só a orientação dessa dissertação mas, também, o apoio em um momento muito delicado na minha vida acadêmica.

Ao Prof. Dr. Eliseu Martins porque, num momento muito difícil, ouviu-me e recomendou-me procurar o Prof. Sérgio de Iudícibus, cuja erudição e maturidade seriam importantes para a tarefa que estava dispondo-me a realizar.

Ao Prof. Dr. Edson Luiz Riccio e ao Prof. Dr. Gilberto de Andrade Martins, membros da banca do exame de qualificação. Nas aulas ministradas pelo Prof. Riccio não só tomei conhecimento da existência do Balanced Scorecard como aprendi muitos outros assuntos interessantes. As observações de ambos, sobre uma versão apresentada para o exame de qualificação, permitiram que algumas lacunas fossem preenchidas e levaram-me a escrever um texto mais objetivo.

Ao Prof. Andy Neely, Professor of Operations, Strategy and Performance and Director of Cranfield School of Management's Centre for Business Performance, que teve a gentileza de enviar-me cópia de um artigo de sua autoria e das transparências da palestra que ministrou em recente conferência, em Cambridge, UK.

Ao Professor Lázaro Partamian Carriel, da PUCAMP, que além de ajudar-me a procurar referências bibliográficas na PUCAMP e na UNICAMP, cedeu-me um simulador interativo, em CD, da Harvard Business School, de autoria de Robert Kaplan \& Douglas Norton. 
Ao Leopoldo G. Barros, da LBarros Desenvolvimento Empresarial, que, na sua atividade como consultor de empresas, tomou conhecimento de uma série de endereços eletrônicos com referências ao Balanced Scorecard, os quais me repassou.

Ao Paulo Roberto Barbosa Lustosa, amigo e co-autor em outros textos, que teve o trabalho de procurar e enviar-me, de Illinois, EUA, vários artigos não disponíveis no Brasil.

Ao Prof. Serge Evraert, Professeur des Sciences de Gestion, Coordinateur des U. F. R. d'Êconomie et Gestion, Université Montesquieu, Bordeaux IV, France, que teve a gentileza de enviar-me cópias de todos os artigos que constam da bibliografia do curso que ministra sobre o Tableau de Bord.

Ao Paulo de Tarso Presgrave Leite Soares, com quem tenho vivido momentos de plena felicidade e emoção e, que foi o responsável pela mudança de curso na minha formação acadêmica e profissional, me orientando, incentivando e dando o apoio necessário, desde o MBA Controller. O fato de já ter passado por esse esforço o faz compreensivo com as consequências da dedicação, mas não reduz o sacrifício pessoal e profissional ao qual foi submetido, que, a despeito de suas próprias prioridades e, apesar das minhas oscilações tempestivas de humor e disposição, se dispôs a ouvir-me e a repassar-me suas experiências em gestão, de forma a ajudar-me a aumentar a compreensão do tema.

Aos meus pais, Paulo e Helena, que apesar das dificuldades, sempre fizeram da minha instrução uma prioridade. Mas talvez o legado fundamental tenha sido o ambiente de leitura e conversas em casa, que me instigavam à curiosidade, à investigação do que estava por trás do aparente, do superficial. Adicione-se a isso, a postura orientada de que se eu estivesse insatisfeita com uma regra, que eu não a burlasse, mas tentasse mudá-la. Toda essa orientação mais o amor, foram fundamentais para percorrer esse caminho de aprendizado.

Erros e omissões remanescentes são de inteira responsabilidade dessa autora. 


\section{R E S U M O}

A dissertação argumenta que, contrariamente ao afirmado por alguns autores, o Balanced Scorecard não é simples repetição de conhecimentos já estabelecidos. Apoiado em critérios extraídos de textos escritos pelos Profs. Fernando Henrique Cardoso e Sérgio de Iudícibus, afirma que o Balanced Scorecard é uma contribuição original à literatura de contabilidade gerencial, não porque trata de temas nunca antes tratados mas porque repensa temas antigos, chamando a atenção para pontos que estavam esquecidos ou mal compreendidos, mostrando a vinculação entre pontos vitais que não estavam claramente articulados. O Balanced Scorecard mostra como esses conhecimentos estabelecidos podem ser aplicados aos tempos modernos, para atender às exigências impostas pelo ambiente mais competitivo para as empresas. O Balanced Scorecard, consequentemente, aumenta a compreensão do tema "vinculação entre estratégia e operação".

A decodificação de temas complexos num particular arranjo, facilitando a integração entre firmas de software e firmas de consultoria, num ambiente ansioso por novas ferramentas gerencias, associadas a subestimação das dificuldades para implantação, para se estabelecer um padrão adequado de medidas e para a vinculação com o sistema de recompensas, levaram a que o Balanced Scorecard tenha virado um modismo. Os problemas com o ensino de contabilidade, apontados por Wickhan Skinner e por David Allen e a falta de uma teoria geral, apontada por por John Kay, ajudam a a entender a vinculação entre a contribuição de Kaplan \& Norton e sua vulgarização. 


\section{A B S T R A C T}

This dissertation argues that the Balanced Scorecard is not a simple reproduction of established knowledge, although some authors have assured the opposite. Rested on criteria extracted from texts written by Profs. Fernando Henrique Cardoso and Sérgio de Iudícibus, this dissertation supports that the Balanced Scorecard is an original contribution to the management accounting literature, not in function of dealing with new issues, but in function of rethinking old knowledge, stressing points that were forgotten or misunderstood, and making explicit the linkages among vital points that were not clear articulated in literature. The Balanced Scorecard indicates how this established knowledge can be applied in nowadays to support/fill the requirements of a more competitive environment faced by companies. The Balanced Scorecard, in consequence, increases the understanding of the theme "linking strategy to action".

The translation of complex themes in a particular arrangement, which facilitated the integration of software and consulting firms, in an environment anxious for new managerial tools, added to the fact that the difficulties to define an adequate standard of measurements, to implement the Balanced Scorecard and to link it to the reward system were underestimated, lead it to become a fad. Problems in teaching accounting pointed out by Wickhan Skinner and by David Allen and the lack of a general theory, pointed out by John Kay, are insights that can help to understand the linkage between the Kaplan \& Norton contribution and its vulgarization. 


\section{$\underline{\text { SUMÁ R I O }}$}

\section{INTRODUÇÃO}

\section{1 - APRESENTAÇÃO.}

1.1 - ANTECEDENTES............................................................................................................. 7

1.2 - UTILIZAÇÃO ORIGINAL E SUAS ALTERAÇÕES ............................................. 10

1.2.1 - A PRIMEIRA UTILIZAÇÃO: MEDIDAS DE DESEMPENHO........................................... 12

1.2.2 - EVOLUÇÃO I: COMUNICAÇÃO E ALINHAMENTO ESTRATÉGICO............................... 14

1.2.3 - EVOLUÇÃo II: SISTEMA DE GESTÃo ESTRATÉGICA................................................. 15

1.3 - O BALANCED SCORECARD SEGUNDO KAPLAN \& NORTON ........................ 17

1.3.1- ESTRATÉGIA..................................................................................................... 18

1.3.2 - TRADUÇÃo DA ESTRATÉGIA EM AÇÕES DE CURTO PRAZO....................................... 19

Figura 1: Gestão Estratégica - Quatro Processos ............................................. 20

1.3.3 - AS MEDIDAS ......................................................................................................... 29

1.3.4 - AS PERSPECTIVAS ............................................................................................... 30

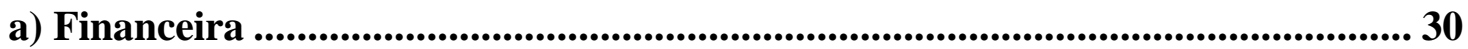

b) Clientes.......................................................................................................... 32

c) Processos Internos.................................................................................................... 36

d) Aprendizado e Crescimento ............................................................................ 38

1.3.5 - INTEGRAÇÃO ENTRE AS PERSPECTIVAS............................................................... 39

Figura 2: Ilustração de um Balanced Scorecard.................................................. 40

Figura 3: Tradução da Visão e Estratégia - Quatro Perspectivas ........................ 44

Figura 4: Integração dos Scorecards - Kenyon Stores ....................................... 45

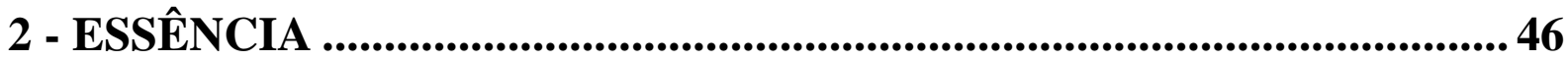

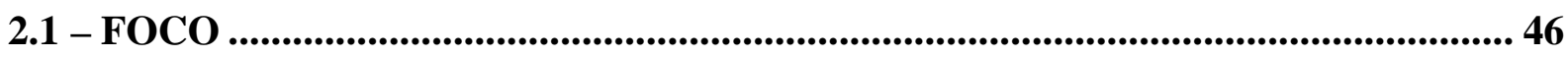

2.2 - CLASSIFICAÇÃO ...................................................................................................... 52

2.3 - ARRANJO SISTÊMICO......................................................................................57

Figura 5: Encadeamento da Estratégia à Ação e Vice-Versa................................ 59

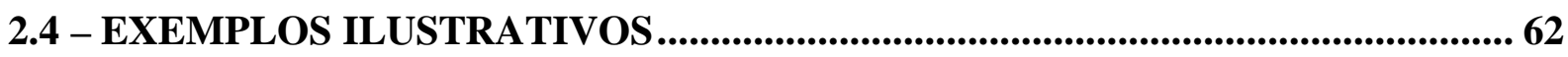

2.4.1 - EXEMPLO COM UM HOSPITAL ESPECIALIZADO ......................................... 62

Figura 6: Exemplo com um Hospital Especializado ........................................... 63

2.4.2 - EXEMPLO COM UMA INSTITUIÇÃO FINANCEIRA ....................................................... 64 
Figura 7: Relacionamento dos Objetivos Estratégicos.................................... 65 Figura 8: Relação entre os Objetivos Estratégicos, os Indicadores e as Medidas 66

3.1 - A COLOCAÇÃO DO PROBLEMA ................................................................................... 68

3.1.1 - PLÁGIO OU CONTRIBUIÇÃO TEÓRICA? .................................................................. 68

3.1.2 - SIGNIFICADO DE CONTRIBUIÇÃO TEÓRICA .................................................... 70

3.2 - CRITÉRIO I: TRATAR DE NOVOS PONTOS ...................................................... 72

3.2.1 - NOVAS MENSAGENS?............................................................................................ 72

a) Estabelecer estratégias definidas com precisão .............................................. 72

b) Ligar operação e estratégia ...............................................................................74

c) Adicionar medidas não financeiras ....................................................... 75

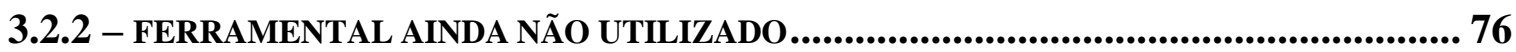

a) Direcionadores de desempenho ............................................................................. 77

b) Relacionamento de causa e efeito.............................................................................. 78

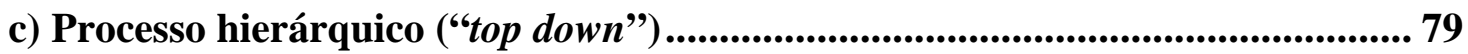

d) Diferentes Perspectivas .......................................................................................... 80

e) Processos gerenciais .............................................................................................. 82

3.2.3 - TÉCNICA AINDA NÃO UTILIZADA................................................................. 83

a) Tableau de Bord ................................................................................................ 84

3.2.4 - PONTOS JÁ ESTABELECIDOS NA LITERATURA ................................................... 86

3.3 - CRITÉRIO II: REPENSAR TEMAS ANTIGOS........................................................ 86

3.3.1 - BALANCED SCORECARD E TABLEAU DE BORD: DIFERENÇAS ............................. 86

3.3.2 - BALANCED SCORECARD E TABLEAU DE BORD: PAINEL DE CONTROLE VERSUS

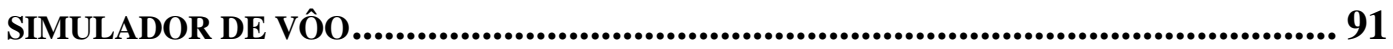

3.3.3 - REPENSAR TEMAS ANTIGOS ................................................................................... 93

3.4 - CRITÉRIO III: ATENDER ÀS EXIGÊNCIAS EMERGENTES ........................ 98

3.4.1 - ÚTIL NO NOVO AMBIENTE COMPETITIVO _......................................................99

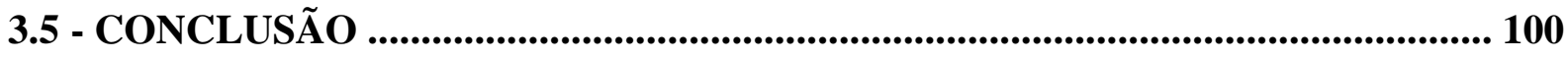

4 - DESDOBRAMENTOS..........................................................................102

4.1 - AMPLA DISSEMINAÇÃO .......................................................................... 102

4.1.1 - AMBIENTE PROPÍCIO.................................................................................................. 102

4.1.2 - DECODIFICAÇÃO DE TEMAS COMPLEXOS........................................................... 104

4.1.3 - INTEGRAÇÃO EMPRESAS DE SOFTWARE - CONSULTORIAS .................................. 108 


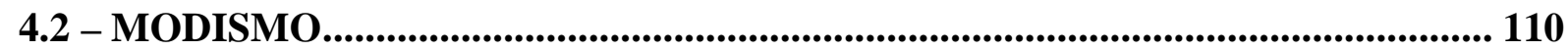

4.2.1 - SUBESTIMAÇÃO DAS DIFICULDADES DE IMPLANTAÇÃO........................................ 112

4.2.2 - SUBESTIMAÇÃO DAS DIFICULDADES ADICIONAIS .................................................. 120

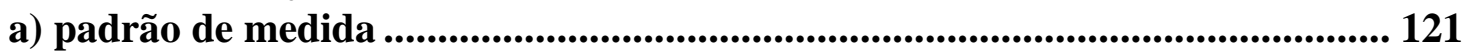

b) vinculação com recompensa ........................................................................................ 12

4.2.3 - CRÍTICAS INDEVIDAS ................................................................................................ 127

4.3 - AMPLA DISSEMINAÇÃO E MODISMO............................................................. 133

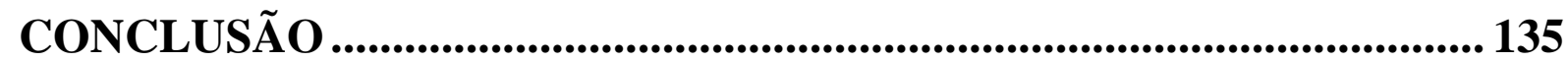

REFERÊNCIAS BIBLIOGRÁFICAS ..................................................... 137

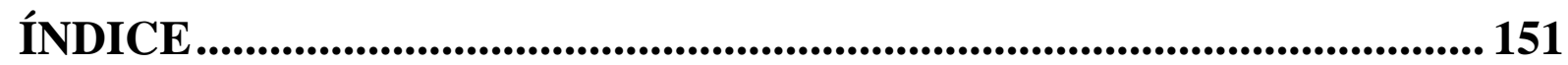




\section{INTRODUÇÃO}

Kaplan \& Norton, em artigo de $1992^{1}$, divulgaram um sistema de medição de desempenho das empresas, que denominaram Balanced Scorecard. Esses autores, a partir de $1996^{2}$, passaram a divulgar sua proposta como um novo sistema de gerenciamento de estratégia das empresas. Ainda em 1996, a divulgação dessa proposta ganhou novas dimensões com a publicação do primeiro livro sobre o assunto ${ }^{3}$. Agora em 2001, no prefácio do segundo livro sobre o assunto ${ }^{4}$, os autores informaram que, passados quatro anos da publicação do primeiro livro sobre o Balanced Scorecard, ele já tinha sido traduzido para dezenove línguas, o que atesta a universalidade de suas características e de sua aplicabilidade.

Há, em várias línguas ${ }^{5}$, uma gama enorme de referências ao Balanced Scorecard. Algumas, acrescentando comentários ou não, basicamente referem-se à sua existência ${ }^{6}$. Outras comentam a importância do tema em conferências internacionais ${ }^{7}$. Outras comentam a sua eficiência em aplicações específicas tais como gerir a integração vertical em sistemas de saúde, gerir o conhecimento (e não o processo de conhecimento), gerir planos de seguridade e plano de pensão, gerir segurança no trabalho, gerir Recursos Humanos, gerir cooperativa de crédito, entre outros ${ }^{8}$. Entre revistas científicas e especializadas em gestão, acessíveis por

\footnotetext{
Kaplan \& Norton (1992).

2 Kaplan \& Norton (1996-a).

3 Kaplan \& Norton (1996-e).

4 Kaplan \& Norton (2001).

5 A autora dessa dissertação apenas acessou parte daquelas em língua inglesa, francesa e portuguesa.

6 Newing (1995), Daly (1996), Booth (1996-b), Drysdale (1996), Clarke (1997), Datta (1997), James \& Hoque (1997), Light (1998), The BMA Group Pty (1999), Frigo \& Krumwiede (2000), Hanson \& Towle (2000).

7 Drysdale (1996), Lukka \& Shields (1999) e Millar (1999) referem-se ao 81 ${ }^{\circ}$ Encontro Anual da American Accounting Association, em Chicago, ao Workshop promovido pelo European Institute for Advanced Studies in Management (EIASM) em Bruxelas, 1998 e à Conferência Pan Européia de Finanças, em Geneva, respectivamente.

8 Devers \& Shortell et al. (1994), Hiebeler (1996), Steinberg (1996), Ingalls Jr (1999), Jones \& Sharma (1999), Grossman (2000), Hanson \& Towle (2000), respectivamente.
} 
serviço internacional de biblioteca via internet, pode-se encontrar cerca de 400 artigos comentando a aplicação, criticando, elogiando ou simplesmente divulgando.

O Balanced Scorecard está sendo comercializado em software por várias empresas especializadas em aplicativos de gestão. O interesse de empresas como a Gentia, PeopleSoft, CorVu, SAP e Lotus e o envolvimento de consultorias como Arthur Andersen, Andersen Consulting e KPMG, indicam o tamanho do mercado para uma ferramenta que aplique o Balanced Scorecard, ou melhor, indica o interesse das empresas em viabilizar a prática desse conceito.

É abundante o relato de experiências de implantação do Balanced Scorecard. A literatura contém relatos de empresas não identificadas ${ }^{9}$ e de empresas mundialmente conhecidas, como o Bank of Montreal, Allstate Corp., AT\&T Corp. ${ }^{10}$, Caterpillar ${ }^{11}$, Xerox, BP Chemicals ${ }^{12}$, Citibank Private Bank ${ }^{13}$, NRO - National Reconnaissance Office ${ }^{14}$, City of Charlotte ${ }^{15}$, que implantaram o Balanced Scorecard. Segundo uma pesquisa feita pela Tower Perrins, dentre as 100 empresas líderes nos Estados Unidos, no ano de 1996, 60\% delas já tinha adotado o conceito de balanced scorecard. ${ }^{16}$. Pesquisa realizada pelo Instituto de Business Intelligence e pela Reinassance Worldwide, no Reino Unido, constatou que 54\% das 272 empresas respondentes, já estava utilizando a abordagem do Balanced Scorecard ${ }^{17}$.

Nos noventa trabalhos apresentados para análise em uma recente conferência internacional sobre o tema "Performance Measurement - Past, Present and Future", realizada

\footnotetext{
9 Vitale \& Mavrinac \& Hauser (1994), Vokurka \& Fliedner (1995), Abernathy (1997).

10 Birchard (1995).

11 Daly (1996).

12 Van de Vliet (1997).

13 Brindley \& Bear (1997).

14 Chesley \& Wenger (1999).

15 City of Charlotte \& Mecklenburg County (1997).

16 Van de Vliet (1997).

17 Van de Vliet (1997).
} 
no Robinson College, Cambridge University, UK, em julho de 2000, foram registradas sessenta e três referências aos textos de Kaplan \& Norton sobre o Balanced Scorecard. Na conferência anterior, realizada em 1998, nos noventa e oito trabalhos, apareceram trinta e seis referências à dupla Kaplan \& Norton.

É natural que tal sucesso teórico e prático sofresse ataques: alguns, claramente indevidos mas outros absolutamente pertinentes. Exemplo deste último é a crítica de John Kay, ex-Diretor da Said Business School, Oxford University, UK, e atualmente Diretor da London School of Economics, na abertura da já referida conferência na Universidade de Cambridge, UK, sobre o passado e o presente da avaliação de desempenho nas empresas.

Criticando a ausência de uma teoria geral de gestão, ele lembrou que a análise interna (geralmente feita com o método de custeio ABC - "Activity Based Costing") não está dirigida para o controle interno (geralmente usando o BSC - Balanced Scorecard) e não antecipa o relatório externo (geralmente feito com o EVA - Valor Econômico Adicionado).

O tipo de crítica acima apresentada não se dirige diretamente ao conceito ou à estrutura do Balanced Scorecard mas à sua falta de ligação com os demais instrumentos de gestão, que decorre da falta de uma teoria geral de gestão. O problema não está principalmente no $B S C$ mas numa área teórica que é composta por instrumentais fragmentados e isolados.

Outras críticas, no entanto, atingem a integridade do trabalho de Kaplan \& Norton. Uma das mais contundentes desse tipo foi feita por David Allen (1999), Sênior do Chattered Institute of Management Accountants (CIMA), UK, ao afirmar que o Balanced Scorecard promete solucionar o que já está contemplado pela contabilidade gerencial e que ele nada mais é do que um processo de orçamentação. Quem conhece a literatura de contabilidade 
gerencial, segundo o referido autor, não pode concordar com Kaplan \& Norton quando estes afirmam ter descoberto algo de novo.

Nessa mesma linha de ataque, Malcolm (1999), com uma certa dose de ironia e desprezo, diz para Allen (1999) que, se Kaplan \& Norton, com o Balanced Scorecard, conseguiram divulgar a mensagem da contabilidade gerencial, era preciso aprender com eles e ser benevolentes, deixando-os pensar terem, de fato, descoberto algo novo.

Allen (1999) e Malcolm (1999), de maneira disfarçada, fazem uma grave acusação: a de que o Balanced Scorecard, desenvolvido por Kaplan \& Norton, é um plágio.

Vem daí a motivação inicial para esta dissertação: o Balanced Scorecard é um plágio ou traz, de fato, novas contribuições para a literatura de contabilidade gerencial? Em outras palavras, o $B S C$ é uma teoria nova, uma novidade, ou uma simples roupagem nova para idéias antigas?

Uma situação parecida com o que acabou de ser relatado ocorreu, nas ciências sociais, com a teoria da dependência desenvolvida por Cardoso \& Faletto (1970). Essa obra foi um enorme sucesso na academia, incluída nas listas de leituras dos cursos de ciências sociais e de economia em inúmeras universidades estrangeiras, e nas lides políticas, fundamentando os discursos dos partidos de esquerda em toda a América Latina, mas foi acusada de ser um plágio de conhecimentos já estabelecidos.

Cardoso (1980), para defender-se da crítica de plágio, apresentou um critério para a definição do que é uma teoria nova, uma contribuição teórica. Segundo consta dessa obra, quase todos os conceitos utilizados nas ciências sociais podem ser relacionados aos autores clássicos mas, mesmo assim, em duas situações, uma teoria pode ser considerada nova: 1) 
quando repensa processos sociais antigos, e; 2) quando recorre a noções e abordagens antigas para caracterizar processos sociais emergentes.

A argumentação de Cardoso (1980) é basicamente correta mas requer uma complementação, para minimizar o mau uso. Ela, na forma com foi exposta, dá margem a que uma utilização menos atenta confunda a questão da originalidade em teoria com uma questão de estilo literário.

Iudícibus (1996) critica os que se utilizam das vinculações com conhecimentos estabelecidos para minimizar as contribuições teóricas recentes que aperfeiçoam a teoria contábil. Extrai-se daí um critério complementar: aumentar a compreensão do tema, aperfeiçoando a teoria.

A presente dissertação contém o resultado de uma investigação teórica sobre o Balanced Scorecard, para saber se ele é uma contribuição original à literatura de contabilidade gerencial ou um plágio de conhecimentos estabelecidos. O instrumento utilizado para responder à questão foi uma combinação dos critérios extraídos de Cardoso (1980) e Iudícibus (1996): apresentar conceitos novos, repensar métodos gerenciais antigos e/ou aplicá-los para atender às exigências recentes, aumentando a compreensão do tema.

O trabalho desenvolvido nesta dissertação pode ser classificado, com base em Martins (1994), como fenomenológico-hermenêutico e bibliográfico pois, com uma pesquisa bibliográfica, procura avaliar e esclarecer as contribuições científicas sobre o assunto, buscando a relação entre o fenômeno e a essência, entre o objeto e o contexto.

O primeiro capítulo faz a apresentação do objeto de estudo. Contém uma exposição resumindo vários textos de Kaplan \& Norton, de modo a descrever o Balanced Scorecard, 
mostrar sua origem, seu surgimento como um sistema de avaliação de desempenho e sua evolução a até o que seus autores chamam de sistema de gestão estratégica.

O segundo capítulo cumpre mais uma etapa na tarefa de compreensão do objeto de estudo, apontando suas características fundamentais: seu foco, sua classificação e seu arranjo sistêmico.

O terceiro capítulo trata da questão básica desta dissertação. Responde às perguntas derivadas dos critérios extraídos de Cardoso (1980) e Iudícibus (1996). Expõe o resultado de uma pesquisa bibliográfica, na literatura de contabilidade gerencial, realizada para responder se o Balanced Scorecard trata de pontos nunca antes abordados, se repensa pontos já estabelecidos ou se aplica conhecimentos antigos para explicar processos emergentes, de maneira a aumentar a compreensão do tema, constituindo-se numa contribuição original à literatura de contabilidade gerencial; ou se o Balanced Scorecard é um simples plágio.

O quarto capítulo trata de um desdobramento do que foi apontado no capítulo anterior, levantando hipótese sobre quais fatores teriam contribuído para que o Balanced Scorecard se tornasse um modismo. 


\section{1 - APRESENTAÇÃO}

Neste capítulo será apresentado o Balanced Scorecard, concebido e desenvolvido por Robert Kaplan e por David Norton, mostrando seus antecedentes, sua idéia original e sua evolução até o presente.

\section{1 - ANTECEDENTES}

Em função do entendimento de que os Estados Unidos havia perdido a liderança de gestão e tecnologia industrial para o Japão, Kaplan (1983) afirmou que havia um novo desafio para a pesquisa na área da contabilidade gerencial, de forma a permitir que as empresas norteamericanas retomassem a liderança perdida. O novo desafio era estabelecer novas medidas de desempenho vis a vis as mudanças nos processos de produção.

Essa nova linha de pesquisa se impunha porque, no novo ambiente competitivo, o sistema contábil tradicional de custos baseados em premissas de produções de longo prazo de produtos padrões, sem mudanças de características e especificações, não era mais relevante.

A contabilidade não havia acompanhado adequadamente essas mudanças e os textos contábeis não continham um mínimo de discussão sobre técnicas, procedimentos ou propriedades da mensuração de produtividade. A mensuração da produtividade, ao que tudo indicava, ainda não havia sido considerada parte da informação que dá suporte aos gestores em suas decisões e em suas atividades de controle. Os efeitos do volume de atividade e da substituição entre mão de obra, capital, materiais, energia entre outras variáveis relacionadas às medidas de produtividade, não tinham sido tema de nenhuma pesquisa contábil.

Essa mudança deveria refletir-se no ensino da contabilidade gerencial. Era importante lecionar recorrendo a exemplos das condições atuais, em que o investimento em um novo 
equipamento se justifica não só pelas economias de mão de obra ou de energia mas, também, por permitir uma programação de produção mais flexível ou mais confiável, reduzindo os níveis de inventário e, consequentemente, os custos totais.

Embora a contabilidade não pudesse desempenhar o papel principal de promover ou implementar inovações tecnológicas e mudanças organizacionais, ela podia desempenhar um papel crítico nesse esforço, desenvolvendo novas medidas não financeiras de desempenho, tais como produtividade, qualidade, custos de inventário entre outras, para avaliar o progresso da empresa em relação àquelas mudanças. Mais ainda, o estudo da estrutura de mercado, da inovação tecnológica e das relações fornecedor-consumidor estavam requerendo insights da ciência econômica. A compreensão dos determinantes de sucesso no desempenho estava requerendo contribuições de várias disciplinas.

Kaplan (1983) ressaltou que o uso de medidas de desempenho mais amplas não só era importante para procedimentos de orçamento de capital e para monitoramento do uso de novas tecnologias e de sistemas de manufatura flexíveis, como deveria estar presente ao longo de todo o processo de gestão.

Como as mudanças nas operações de manufatura eram relativamente recentes e suas implicações, portanto, não eram totalmente conhecidas, era difícil definir uma agenda de pesquisas completa e precisa. Era possível, no entanto, identificar vários assuntos que deveriam ser objeto de preocupação dos pesquisadores para os próximos anos. Medir a qualidade e entender a relação entre uma qualidade maior e custos menores (inclusive, testando se essa relação se sustenta na prática), por exemplo, fariam parte do escopo de uma nova e valiosa área de pesquisa. Outros tópicos sugeridos para pesquisa foram:

1) a substituição do sistema tradicional de custos padrões; 
2) o desenvolvimento de novos procedimentos para a predição e controle de custos considerando o ambiente da fábrica do futuro (altamente automatizada, de manufatura flexível);

3) a exploração da relevância do papel que a produtividade deve desempenhar na gestão (aumento de produtividade em uma área nem sempre significa aumento de rentabilidade para a empresa);

4) a validação da relação entre decréscimos nos custos operacionais e decréscimos nos defeitos dos produtos (o quanto se economiza evitando retrabalhos, consertos, restos etc.);

5) o aperfeiçoamento dos procedimentos de gestão de inventário;

6) a expansão dos procedimentos do orçamento de capital de forma a incorporar os benefícios medidos de melhoria de qualidade, flexibilidade e mudanças que podem ser conseguidas por investimentos em tecnologia de manufatura;

7) a investigação do porque que as empresas tendem a usar para o planejamento e controle internos, os mesmos procedimentos contábeis usados com o propósito de reporte externo; entre outros.

A nova ordem, segundo Kaplan (1983), era produzir para clientes mais que para inventários, fazendo com que os sistemas flexíveis de manufatura também impusessem a necessidade de um novo sistema de custo padrão.

A crítica aos sistemas tradicionais de contabilidade gerencial reaparece em Johnson \& Kaplan (1987), onde foi dito que os novos rumos, propostos em Kaplan (1983), ainda não haviam sido adotados pela contabilidade gerencial. 
Os sistemas tradicionais de mensuração de desempenho, como suporte à gestão das grandes empresas com múltiplas atividades e produtos, foram criticados por não as auxiliarem na avaliação da eficiência dos processos e da lucratividade de seus produtos. $\mathrm{O}$ foco excessivo em medidas financeiras de curto prazo também foi alvo de crítica nessa obra.

Os sistemas gerenciais contábeis pobres não eram os únicos causadores das falhas das empresas mas, davam uma contribuição importante para essas falhas. Os gestores precisavam definir os fatores chaves estratégicos que deveriam guiar a empresa, pois é impossível atingir todos os objetivos ao mesmo tempo. Esses fatores chaves estratégicos, assim como o desenho do novo sistema gerencial, segundo Johnson \& Kaplan (1987), não podiam ser definidos pelos contadores gerenciais, precisavam ser definidos com o envolvimento da alta administração.

O sistema de mensuração denominado $A B C$ - Activity Based Cost, desenvolvido como uma alternativa para suplantar a insatisfação com os sistemas tradicionais na avaliação da eficiência dos processos e da lucratividade dos produtos, aparece anos mais tarde, em Cooper \& Kaplan et al. (1992).

O Balanced Scorecard, indicando como decidir sobre o que deve ser medido (os fatores chaves estratégicos) e como essas informações devem ser dispostas para que possam ter maior utilidade na gestão do negócio, aparece em Kaplan \& Norton (1992).

\section{2 - UTILIZAÇÃO ORIGINAL E SUAS ALTERAÇÕES}

Devido ao entendimento de que as tradicionais medidas contábeis e financeiras não mais ajudavam, ao contrário, dificultavam a empresa a criar valor econômico para o futuro, David Norton, executivo do Instituto de Pesquisa da Nolan Norton, unidade de pesquisa da KPMG, sob consultoria acadêmica de Robert Kaplan, em 1990, realizou um estudo, em várias empresas, com o objetivo de desenvolver um novo modelo de medidas de desempenho. 
O ponto de partida foi o modelo usado pela Analog Devices para medir o índice de progresso em atividades de melhoria contínua e o seu scorecard, que continha as medidas tradicionais financeiras e outras operacionais. O estudo foi direcionado para chegar-se a um scorecard multidimensional. Posteriormente, para indicar a característica de equilíbrio (balanceamento) entre medidas de curto e de longo prazo, entre as medidas financeiras e as não financeiras, entre os indicadores de tendência (leading) e os de ocorrências (lagging) e entre as perspectivas interna e externa de desempenho, esse scorecard multidimensional passou a ser referido como "Balanced Scorecard".

Depois do teste da viabilidade de implantação em alguns setores de algumas empresas, esse sistema de medição foi exposto em Kaplan \& Norton (1992).

Após essa divulgação, dois executivos de duas empresas (Rockwater e FMC Corporation) solicitaram ajuda para implantar aquele sistema de indicadores. Esses executivos tinham a intenção de usar o referido sistema de indicadores para comunicar as estratégias e a elas alinhar as empresas que dirigiam.

O que esses executivos mostraram foi exposto em Kaplan \& Norton (1993). O Balanced Scorecard podia ser utilizado de uma maneira diferente da que vinha sendo proposta. Apesar de desenvolvido para ser um sistema de medição de desempenho, ele podia ser utilizado para comunicar e alinhar a estratégia da empresa.

As experiências com outras dez empresas mostraram que um conjunto de medidas associado a quatro perspectivas definidas no Balanced Scorecard comunicava e ajudava a implementar uma estratégia consistente. Essas experiências demonstraram a importância de se montar um conjunto de medidas que descrevesse a trajetória estratégica da empresa e ajudaram a refinar o sistema. 
A prática mostrou que os gestores podiam utilizar o sistema não só para comunicar a estratégia mas, também, para gerenciá-la. Kaplan (1994-b) registrou que o sistema de mensuração, que havia se transformado em sistema de comunicação e alinhamento estratégico, estava começando a ser explorado como um sistema de gerenciamento de estratégia. Posteriormente, em Kaplan \& Norton (1996-a), o Balanced Scorecard passou a ser apresentado como um sistema gerencial essencial.

Cinco artigos e um livro, publicados nesse ano de 1996, expõem uma expressiva mudança de enfoque, que não é demais ressaltar: o que originalmente era um sistema de medição e se transformara num sistema de comunicação e alinhamento estratégico, acabara transformando-se num sistema de gerenciamento.

Esse processo de desenvolvimento, de transformação, culmina em Kaplan \& Norton (2001), um livro cujo tema central é uma nova forma organizacional, a organização focada na estratégia, em que o principal instrumento de gestão é o Balanced Scorecard.

\subsection{1 - A PRIMEIRA UTILIZAÇÃO: MEDIDAS DE DESEMPENHO}

As tradicionais medidas financeiras e mesmo as inovações ocorridas nesse campo, tais como valor econômico adicionado (EVA), refletem transações que já ocorreram. Elas constituem-se, portanto, em indicadores de ocorrências (lagging).

O ambiente ultra competitivo, de rápidas mudanças, no entanto, impõe aos gestores a necessidade não só de avaliar o desempenho passado mas também de saber se eles estão criando valor futuro ${ }^{18}$. A criação de valores futuros exige a exploração de valores intangíveis. Na Era da Informação, saber explorar ativos intangíveis é mais importante que saber investir e administrar ativos físicos ${ }^{19}$.

\footnotetext{
18 Kaplan (1994-a, p.15).

19 Kaplan \& Norton (1996-a, p.75).
} 
Qualquer medida única possui propriedades de miopia que pode permitir que o gestor melhore seu desempenho avaliado por aquela medida sem necessariamente contribuir para os lucros de longo prazo da empresa ${ }^{20}$. É necessário, por conseguinte, usar indicadores de tendências (leading) pois não existe uma medida única sumariando as metas que precisam ser alcançadas com a finalidade de criação de valor futuro.

O Balanced Scorecard original tinha o objetivo de aumentar a abrangência das medidas de desempenho da empresa sem inundá-la de indicadores. Assim como o piloto de um avião dispõe, no painel de controle da aeronave, de um conjunto sucinto de informações relevantes, o gestor deve poder contar com um conjunto sucinto de medidas relevantes para a análise de desempenho de várias áreas.

O Balanced Scorecard trazia a novidade de reunir, em apenas um relatório, as medidas que indicavam o alcance daquelas metas necessárias para a criação de valor futuro, combinando a diversidade de elementos típicos de uma empresa com agenda competitiva. Isso, para a empresa, significa: 1) tornar-se orientada para seus clientes; 2) ser capaz de dar respostas rápidas; 3) qualificar a equipe de trabalho; 4) reduzir o tempo de lançamento de novos produtos; e, 5) gerir para o longo prazo.

Esse conjunto de medidas balanceadas (em equilíbrio) não desconsidera as medidas financeiras tradicionais, mas complementam-nas com medidas operacionais que podem ser vistas como direcionadoras de futuros desempenhos financeiros ou melhor, como fatores que direcionam os valores futuros. Como expressa o título do primeiro artigo ${ }^{21}$, são medidas que conduzem/dirigem o desempenho.

\footnotetext{
${ }^{20}$ Kaplan $(1983$, p.699) sugere para uma discussão mais detalhada sobre as limitações das medidas de desempenho unidimensionais e o papel das medidas de desempenho multidimensionais, o Capítulo VIII de SOLOMONS, David. Divisional Performance: measurement and control. Homewood, IL: Richard D. Irwin, 1965.

21 "The Balanced Scorecard - measures that drive performance".
} 
A intenção, com a construção do Balanced Scorecard, era ter um conjunto de medidas de desempenho que monitorasse a capacitação e a conquista de ativos intangíveis necessários para o crescimento futuro ${ }^{22}$.

\subsection{2 - EVOLUÇÃO I: COMUNICAÇÃO E ALINHAMENTO ESTRATÉGICO}

Muitas empresas incorporaram medidas de desempenho não financeiras mas o fizeram a partir da necessidade de se alcançar objetivos específicos (gestão de qualidade total, redução de ciclo, reengenharia etc.). E, um conjunto de medidas não financeiras, voltadas para o desempenho passado e não relacionadas aos objetivos estratégicos específicos é uma limitada aplicação do Balanced Scorecard.

O Balanced Scorecard não é um conjunto de indicadores derivados de processos ad hoc. As medidas de desempenho devem ser desenhadas a partir de uma concepção geral da estratégia da empresa e não a partir das necessidades específicas de cada área ${ }^{23}$. A ferramenta requer que sejam estabelecidas medidas que efetivamente indiquem se a estratégia delineada pela organização está sendo implementada e executada satisfatoriamente.

As experiências com a Rockwater e com a FMC Corporation, de implantação do novo sistema de mensuração, mostraram que o Balanced Scorecard permitia identificar os desempenhos necessários nos processos estratégicos. Percebeu-se, então, que ele era um sistema eficiente para comunicar a estratégia da empresa e para o alinhamento das atividades a essa estratégia. Percebeu-se que ele atendia a um ponto salientado por Kaplan (1983, p. 702): “A empresa deve selecionar, para reportes internos, aquelas práticas que melhor promovem incentivos para alcançar sua estratégia e objetivos".

Kaplan \& Norton (1996-a, p.75) e Kaplan \& Norton (1996-b).

23 O Balanced Scorecard considera as necessidades específicas de cada área se elas forem determinantes do desempenho da empresa no cumprimento da estratégia delineada. A ordem dos fatores, nesse caso, altera o produto. 
Não há um conjunto de medidas de desempenho genérico. Cada empresa tem uma missão, uma visão, uma estratégia e, portanto, um conjunto de medidas adequado. A proposta é derivar esse conjunto de indicadores de acordo com a missão da empresa, sua estratégia, tecnologia e cultura. Assim, diferentes situações de mercado, estratégias de produtos e ambientes competitivos requerem diferentes scorecards. O ponto central do modelo não é o controle e sim, a visão, a missão da empresa ${ }^{24}$.

\subsection{3 - EVOLUÇÃO II: SISTEMA DE GESTÃO ESTRATÉGICA}

O uso do Balanced Scorecard como um instrumento de comunicação e alinhamento da estratégia da empresa explicitou uma séria deficiência nos sistemas gerenciais tradicionais, qual seja, a inabilidade para ligar a estratégia de longo prazo da empresa com as suas ações de curto prazo.

"Muitas pessoas pensam em mensuração como uma ferramenta para controlar comportamentos e para avaliar desempenhos passados. Controles e sistemas de mensuração tradicionais pretendem manter unidades organizacionais de acordo com um plano pré estabelecido. As medidas no Balanced Scorecard estão sendo usadas pelos executivos de forma diferentepara articular a estratégia do negócio, comunicá-la e ajudar a alinhar as iniciativas individuais, organizacionais e departamentais, para alcançar um objetivo comum. Esses executivos estão usando o scorecard como um sistema de comunicação, informação e aprendizado, não como um sistema tradicional de controle. Para que o Balanced Scorecard seja usado dessa maneira, entretanto, as medidas devem expressar claramente a estratégia de longo prazo da organização para o sucesso competitivo." (Kaplan \& Norton, 1996-c, p.56)

O Balanced Scorecard, então, passa a ser visto por seus autores como um instrumento que traduz a estratégia da empresa em objetivos específicos mensuráveis - tanto os de longo prazo quanto os de curto. Assim, da percepção de que o Balanced Scorecard podia ser usado para comunicar e alinhar a estratégia da empresa, bastou um passo lógico para a percepção de que ele podia ser utilizado como um novo sistema de gestão estratégica.

${ }^{24}$ Kaplan \& Norton (1992), Kaplan \& Norton (1993) e Kaplan (1994-a). 
A metáfora usada para expressar a diferença entre o que se pode gerir com os sistemas gerenciais tradicionais e com o Balanced Scorecard é a diferença entre pilotar um navio isolado por um ambiente estável até o seu destino e pilotar um barco em uma competição (sob mudanças nas condições de tempo e do mar) ${ }^{25}$.

O modelo de comando e controle de uma organização é similar ao do capitão de um navio (executivo-chefe), que determina a direção e a velocidade que o navio (unidade de negócio) deve navegar. Os marinheiros (gestores e funcionários de linha de frente) seguem as ordens e implementam os planos determinados pelo capitão. Os sistemas operacionais e de controle gerencial são estabelecidos para garantir que os gestores e funcionários ajam de acordo com o plano estratégico estabelecido pelos executivos seniores. Esse processo linear de estabelecer uma visão e uma estratégia, comunicá-la e ligá-la a todos na organização e alinhar as ações e iniciativas para alcançar os objetivos de longo prazo é um exemplo de processo simples de realimentação (single-loop feedback process). Nesse processo, o objetivo permanece constante. Esse processo não leva as pessoas a questionar se o objetivo a ser alcançado permanece viável ou se os métodos usados para alcançá-los ainda são os apropriados. Apenas serve para monitorar desvios em relação ao planejado.

Em uma competição de barcos, o canal de comando ainda existe mas o capitão monitora o ambiente continuamente e, freqüentemente, reage taticamente e estrategicamente às mudanças no comportamento dos competidores, da equipe e das capacitações do barco, das condições do vento e das correntes. O capitão ainda deve receber informações de uma grande quantidade de fontes tais como observação do pessoal, dos instrumentos e medidas e, especialmente, da opinião dos táticos do barco que também inspecionam as condições e traçam planos.

${ }^{25}$ Kaplan \& Norton (1996-d). 
O Balanced Scorecard revelou-se um importante instrumento de ajuda aos gestores no ambiente competitivo moderno, semelhante ao do barco numa competição em que as condições do tempo e do mar são continuamente alteradas. As organizações, situadas em um ambiente em constante mudança, precisam de um processo duplo de aprendizado (doubleloop learning process). Esse processo permite que o gestor questione as hipóteses traçadas e reflita sobre se a teoria sob a qual opera ainda está consistente com as evidências, observações e experiências correntes.

Segundo Kaplan \& Norton (1996-d, p.20), é claro que os gestores precisam saber se sua estratégia planejada está sendo executada de acordo com o plano - um processo simples de aprendizado. Mas mais importante que isso, precisam saber se as hipóteses fundamentais traçadas quando do lançamento da estratégia permanecem válidas.

Muitos gestores, portanto, começaram a integrá-lo ao sistema de planejamento e orçamentação. O verdadeiro potencial do Balanced Scorecard se realiza quando ele deixa de ser um sistema de mensuração de desempenho e passa a ser um sistema de gestão estratégica.

\section{3 - O BALANCED SCORECARD SEGUNDO KAPLAN \& NORTON}

O Balanced Scorecard, tal como entendido por Robert Kaplan e por David Norton, é um sistema de gestão estratégica que se propõe a ajudar as empresas a traduzirem suas estratégias em ações. Ele trata da definição e disposição das informações chaves para gerenciar o cumprimento da estratégia da empresa e dos processos gerenciais que promovem o alinhamento estratégico necessário para tal definição. 


\subsection{1- ESTRATÉGIA}

A estratégia da empresa é definida ${ }^{26}$ como um conjunto de hipóteses sobre os relacionamentos de causa e efeito entre: a) os objetivos e as ações necessárias para que eles sejam alcançados; b) entre os objetivos e as medidas do desempenho obtido no esforço de alcançá-los.

O relacionamento causa e efeito pode ser expresso por uma seqüência de afirmações do tipo "se-então". Para definir a estratégia da organização, portanto, é preciso fazer algumas suposições sobre certos relacionamentos. Por exemplo, a organização pode estabelecer uma ligação entre treinamento de pessoal e maior volume de vendas através da seguinte seqüência de hipóteses:

$\underline{\boldsymbol{S e}}$ aumentarmos o treinamento dos funcionários sobre os produtos, $\underline{\text { então }}$ eles estarão melhor informados sobre os produtos que vendem;

$\underline{\text { Se }}$ os funcionários estiverem melhor informados sobre os produtos que vendem, $\underline{\text { então }}$ a eficácia nas vendas melhorará;

$\underline{\boldsymbol{S} \boldsymbol{e}}$ a eficácia nas vendas melhorar, $\underline{\text { então }}$ a média das margens dos produtos que vendem aumentará.

Os objetivos de curto prazo derivados do Balanced Scorecard refletem a melhor previsão dos gestores quanto a magnitude e velocidade de resposta entre mudanças nos direcionadores de desempenho futuro e as mudanças a elas associadas em uma ou mais medidas de resultado (de esforços despendidos no passado). No exemplo acima, os objetivos deveriam explicitar o tempo necessário para que o treinamento de pessoal se converta em melhorias de desempenho das vendas e em quanto essas melhorarão.

$\overline{{ }^{26} \text { Kaplan \& Norton (1996-c, p.65). }}$ 
As estratégias, então, são definidas a partir de premissas, de uma visão do mundo e de hipóteses sobre o relacionamento causa e efeito entre os fatores de sucesso. Se houver erros nas premissas, a estratégia de longo prazo definida pode não ser a lucrativa. Nesse caso, podese ter um conjunto adequado de indicadores, corretamente inter-relacionados, que não será suficiente para orientar a gestão. Se houver erros nas hipóteses sobre o relacionamento causa e efeito entre as variáveis, pode-se ter estabelecido um conjunto de indicadores não apropriado para orientar a execução da estratégia estabelecida.

Os autores resumem a importância de se construir um balanced scorecard adequado, que conte acuradamente a história da estratégia da unidade de negócio:

"Primeiro, o scorecard descreve a visão do futuro de toda a organização. Se a visão está errada, o fato dela ser executada bem, torna-se irrelevante. Segundo, o scorecard cria entendimento compartilhado. Ele cria um modelo holístico da estratégia que permite que todos os funcionários vejam como eles podem contribuir para o sucesso da organização. Se o modelo está errado, os indivíduos e os departamentos irão, sem saber, sub-otimizar seus desempenhos. Terceiro, o scorecard tem como foco os esforços de mudança. Se os indicadores de tendência estiverem corretamente identificados, os investimentos e iniciativas levarão aos resultados de longo prazo esperados. Se não, investimentos serão desperdiçados. E, finalmente, o scorecard permite o aprendizado organizacional ao nível dos executivos. Ao tornar explícitas as hipóteses de causa e efeito entre os objetivos e medidas, as organizações podem testar suas estratégias a tempo real e adaptá-las conforme aprendem. Sem explicitar as ligações de causa e efeito, nenhum aprendizado estratégico ocorrerá." 27

\subsection{2 - TRAdUÇÃo DA ESTRATÉGIA EM AÇÕES DE CURTO PRAZO}

Quatro processos gerenciais, que devem ser geridos tanto separadamente quanto de forma combinada, permitirão, aos gestores, identificar os indicadores que, por uma relação de causa e efeito, estabelecerão a ligação entre os objetivos estratégicos e as ações de curto prazo. Esses processos gerenciais, cuja descrição e inter-relacionamento são mostrados na Figura 1, foram assim denominados pelos autores: a) "tradução da visão" (translating the

${ }^{27}$ Kaplan \& Norton (1996-c, p.77). 
vision); b) "comunicação e vinculação" (communicating and linking); c) "planejamento" (business planning), e; d) "realimentação e aprendizado" (feedback and learning).

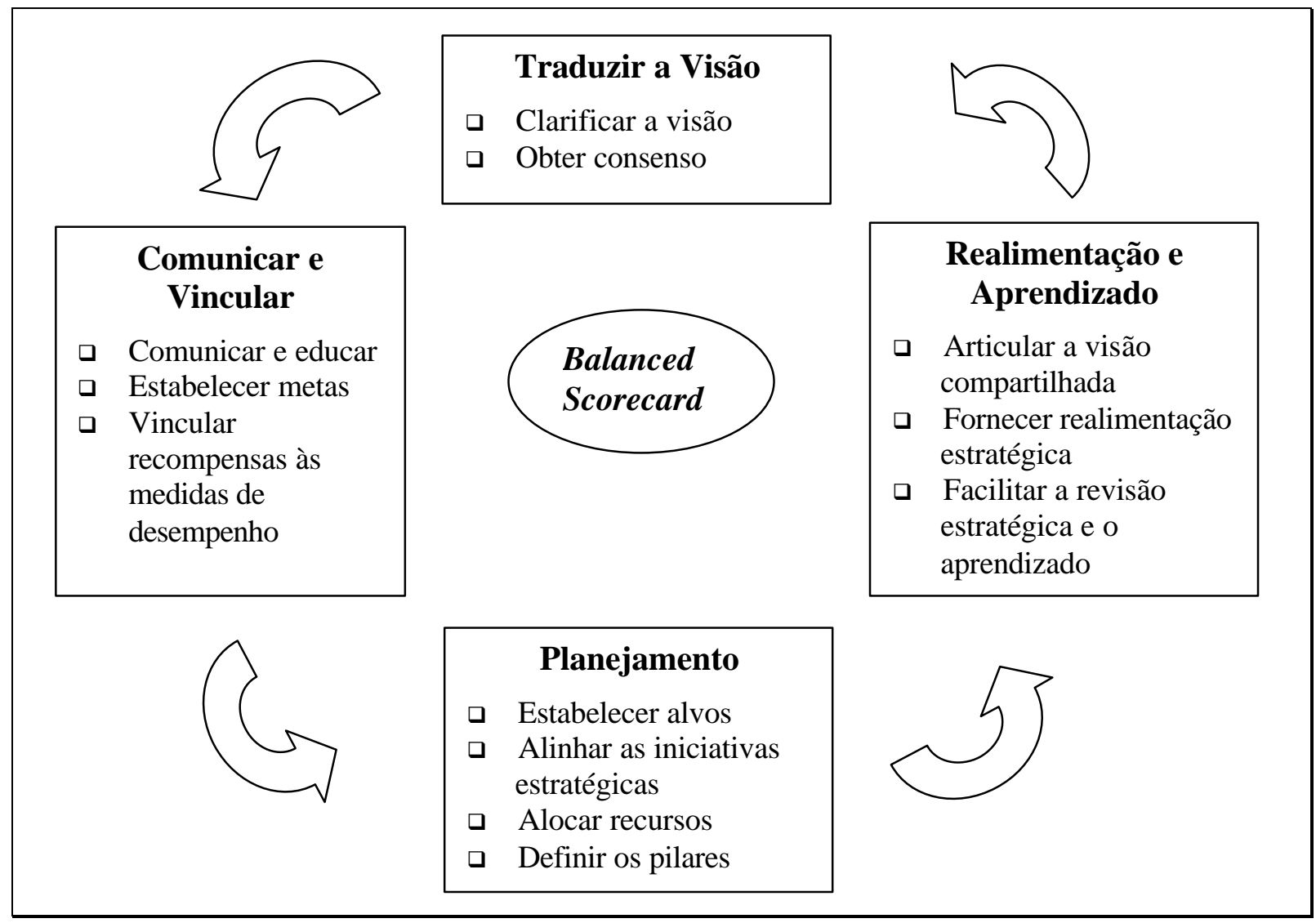

Fonte: Adaptação do quadro “Managing Strategy: Four Processes” (Kaplan \& Norton, 1996-a, p77).

\section{Figura 1: Gestão Estratégica - Quatro Processos}

O primeiro processo, da tradução da visão da organização (translating the vision) ${ }^{28}$, tem como objetivo construir um consenso em torno da visão da empresa e da estratégia necessária para tanto. Esse consenso é fundamental para expressá-las em um conjunto integrado de objetivos e medidas, que descrevem os direcionadores de sucesso de longo prazo e refletem a forma como a empresa pretende transformar ativos intangíveis em ativos tangíveis.

${ }^{28}$ Kaplan \& Norton (1992), Kaplan \& Norton (1996-a), Kaplan \& Norton (1997), Kaplan \& Norton (2001). 
Diferentemente das medidas tradicionais, usualmente definidas por financistas, a definição das medidas, no Balanced Scorecard, deve envolver a alta administração e gerentes seniores, portadores de um quadro mais completo da visão da empresa e de suas prioridades.

Uma participação ampla dos funcionários na construção do scorecard pode demandar tempo mas oferece muitas vantagens: incorporação de informações de um grande número de gestores aos objetivos internos, uma melhor compreensão por parte dos gestores dos objetivos estratégicos de longo prazo da empresa e um forte comprometimento para alcançar tais objetivos.

A participação dos gestores, no entanto, é apenas o primeiro passo para ligar as ações individuais aos objetivos corporativos. É preciso que toda a empresa compartilhe da estratégia e das metas de longo prazo da organização para que os funcionários compreendam melhor como suas atuações específicas contribuirão para a realização daquelas e possam alinhar suas prioridades.

O segundo processo da comunicação da estratégia pela organização e a ligação, propriamente, aos objetivos individuais e departamentais (communicating and linking) ${ }^{29}$, portanto, tem como objetivo criar uma sinergia capaz de fazer com que o desempenho geral seja maior que a soma dos desempenhos individuais.

Como essa tarefa envolve um grande número de pessoas, as organizações que usam scorecards recorrem, em geral, à três mecanismos integrados para traduzir a estratégia em objetivos locais: 1) comunicação e educação; 2) estabelecimento de objetivos; e, 3) ligação de recompensas às medidas de desempenho.

${ }^{29}$ Kaplan \& Norton (1996-a) e Kaplan \& Norton (2001). 
A comunicação e educação constituem um processo contínuo na organização para que todos compreendam os componentes da estratégia e recebam as informações sobre os resultados alcançados. Quando a estratégia e os planos são compartilhados por toda a organização, é mais fácil estabelecer os objetivos individuais e das equipes. Para que o desempenho global desejado seja efetivamente alcançado, os programas de incentivo e compensação devem ser vinculados aos scorecards.

Depois de se alinhar os recursos humanos à estratégia é preciso estabelecer as prioridades das ações e a alocação dos recursos de acordo com ela. O terceiro processo, de planejamento (business planning) ${ }^{30}$, portanto, tem como objetivo integrar os planos financeiros com os corporativos.

O desafio está em aprender a estabelecer ligações entre a operação e as finanças. Essa ligação é explicitada na integração dos processos de planejamento e orçamento, de forma que mesmo os orçamentos de curto prazo, contemplem medidas para as perspectivas de cliente, processos internos e aprendizado e crescimento, além das tradicionais financeiras (todas alinhadas à estratégia) ${ }^{31}$.

Kaplan \& Norton ${ }^{32}$ disseram que a maioria das empresas que implementou programas de mudanças (cada um com seus campeões, gurus, consultores) falhou em integrar essas iniciativas aos objetivos estratégicos. O resultado, consequentemente, foi a frustração de expectativas. A razão do insucesso está em que essas iniciativas (reengenharia, gestão da qualidade total etc.) competem entre si pelos mesmos recursos escassos, incluindo aí o mais escasso de todos: a atenção e o tempo dos gestores seniores.

\footnotetext{
30 Kaplan \& Norton (1996-a).

31 Kaplan \& Norton (2001, p.14), relataram que as empresas que implantaram o Balanced Scorecard com sucesso descobriram que é essencial ter dois tipos de orçamento: o estratégico e o operacional.

32 Kaplan \& Norton (1992) e Kaplan \& Norton (1996-a).
} 
Quando se usa o Balanced Scorecard como base para alocar os recursos e estabelecer as prioridades, o tempo e a atenção desses mesmos gestores têm que ser canalizados para aquelas iniciativas que são fundamentais para direcionar a empresa aos objetivos estratégicos de longo prazo.

Ao identificar o que é crítico para o sucesso, o Balanced Scorecard exige que todos os gestores, tanto no nível operacional quanto no nível superior, centralizem suas atenções para esse reduzido conjunto de fatores críticos de sucesso. Uma vez definida a estratégia e identificados os direcionadores, o scorecard faz com que os gestores se concentrem em melhorar ou redesenhar aqueles processos críticos para o sucesso estratégico da organização. Essa é a forma mais clara de como o scorecard liga e alinha as ações à estratégia.

O passo final para fazer essa ligação, é estabelecer objetivos específicos de curto prazo ou "pedras fundamentais" (milestones) para as medidas do Balanced Scorecard.

As "pedras fundamentais" são expressões tangíveis das crenças dos gestores sobre quando e em que intensidade seus programas atuais afetarão aquelas medidas. Ao estabelecer as "pedras fundamentais", os gestores estão expandindo o processo tradicional de orçamentação para incorporar objetivos estratégicos.

Os processos de planejamento e de orçamentação tradicionais, freqüentemente, são conduzidos erroneamente nas empresas. Muitas delas têm procedimentos e até unidades organizacionais separadas para planejamento estratégico e para alocação de recursos e orçamentação.

Para formular seus planos estratégicos, os executivos seniores passam alguns dias no ano, fora da organização, em discussões facilitadas por gerentes seniores de planejamento e desenvolvimento ou por consultores externos. O resultado desse exercício é um plano estratégico contemplando onde a empresa tem expectativa de estar (ou tem esperança ou reza 
para estar) em três, cinco e dez anos. Tipicamente, tais planos ficam guardados pelos próximos doze meses.

Enquanto isso, os processos de alocação de recursos e de orçamentação são preparados pela equipe de finanças, estabelecendo objetivos financeiros para receitas, despesas, lucros e investimentos para o próximo ano. Esse orçamento é quase que inteiramente elaborado com números financeiros e geralmente tem pouca relação com os objetivos dos planos estratégicos.

O exercício de elaborar um balanced scorecard força a companhia a integrar seus processos de planejamento e orçamentação e assim ajuda a garantir que seus orçamentos suportem suas estratégias ${ }^{33}$.

O Balanced Scorecard ajuda a definir o foco correto, ajudando a empresa a alcançar os objetivos estratégicos de longo prazo:

"Sua empresa adota todas as modas de gestão que surgem sob o céu? Ao usar o Balanced Scorecard para planejar e para orçar, você aprenderá quais servem para sua estratégia e quais não. "34

"Mais importante, quando se usa o Balanced Scorecard para guiar as iniciativas estratégicas, pode-se focar nas questões que promovem o crescimento, e não apenas naquelas que reduzem custos e aumentam a eficiência." 35

"O Balanced Scorecard é como um prisma pelo qual todos os investimentos são focados. Ao invés de uma centena de pontos de luz, tem-se um laser. Toda a energia é direcionada para poucos críticos objetivos." 36

$\mathrm{O}$ quarto processo, de realimentação e aprendizado (feedback and learning) ${ }^{37}$, serve para que, em tempo real, em função da experiência adquirida (aprendizado), a empresa modifique suas estratégias, caso seja necessário. Nesse processo, os resultados de curto prazo

\footnotetext{
33 Kaplan \& Norton (2001, p.14-15) relataram que as empresas que implantaram o Balanced Scorecard com sucesso definiram reuniões específicas para discuti-lo, criando uma energia diferente na empresa, favorável à comunicação da estratégia e ao aprendizado por todos os envolvidos.

34 Kaplan \& Norton (1996-f, p.30).

35 Kaplan \& Norton (1996-f, p.32).

36 Kaplan \& Norton (1996-f, p.32).

37 Kaplan \& Norton (1996-a) e Kaplan \& Norton (1997).
} 
são monitorados pelo aspecto financeiro e por mais três outros aspectos: a) clientes; b) processos internos; e, c) recursos humanos e sistema de informação. A estratégia, portanto, é avaliada à luz do desempenho recente.

Ao relacionar medidas financeiras com medidas referentes aos clientes, aos processos internos, às inovações e ao aprendizado da organização, o Balanced Scorecard ajuda os gestores a entender muitos inter-relacionamentos, permitindo que esses transcendam as tradicionais noções de barreiras funcionais e, por conseguinte, tomem melhores decisões. $\mathrm{O}$ simples fato do gestor ser obrigado a pensar sistematicamente nos relacionamentos causa e efeito, a refletir sobre as suposições subjacentes às estratégias, constitui uma vantagem em relação às práticas correntes de tomada de decisão sobre resultados operacionais de curto prazo.

Kaplan \& Norton, em vários textos, reconhecem que é mais fácil falar de tais relacionamentos do que estabelecê-los. Recomendam, por isso, que eles, inicialmente, devam ser estabelecidos subjetivamente e qualitativamente. Com o passar do tempo, com a experiência, as organizações vão acumulando informações e evidências para estabelecer esses relacionamentos de maneira mais objetiva. Uma vez estabelecidos de maneira objetiva, o Balanced Scorecard pode, então, ser modelado por uma abordagem dinâmica de sistemas (systems dynamics) que provém um modelo quantificado e compreensível do processo de criação de valor do negócio.

O aprendizado permite validar a estratégia e saber como ela está sendo operacionalizada. O sistema dinâmico permite que se reafirme a convicção sobre a estratégia ou que se reconheça a necessidade de alterá-la (ou alterar as medidas) em função de novos conhecimentos sobre as condições de mercado ou capacidades internas (processo duplo de aprendizado). 
Em qualquer das duas situações, o Balanced Scorecard estará estimulando o aprendizado, dos altos executivos, sobre a viabilidade e validade de suas estratégias. A esse processo de aprendizagem dos gestores, que permite o teste de hipóteses e tem o caráter de processo duplo de aprendizado (double loop learning), é dado o nome de aprendizado estratégico. Os autores resumem esse processo nos trechos a seguir:

"Aprendizado estratégico consiste em obter respostas, testar hipóteses sob as quais a estratégia foi baseada, e fazer os ajustes necessários.

O Balanced Scorecard fornece os três elementos que são essenciais ao aprendizado estratégico. Primeiro, expressa a visão compartilhada da companhia, definindo em termos claros e operacionais os resultados que essa, como um time, está tentando alcançar.

(...) Segundo, o scorecard fornece o sistema essencial de resposta estratégica. A estratégia de um negócio pode ser vista como um conjunto de hipóteses sobre relacionamentos de causa e efeito. Um sistema de resposta estratégica deve ser capaz de testar, validar e modificar as hipóteses que sustentam as estratégias das unidades de negócios.

(...) Terceiro, o scorecard facilita a revisão da estratégia que é essencial para o aprendizado estratégico (...) O Balanced Scorecard, com suas especificações das relações causais entre direcionadores de desempenho e objetivos, permite aos executivos corporativos ou de unidades de negócios, usar suas sessões periódicas de revisão para avaliar a validade das estratégias das unidades e a qualidade de suas execuções." 38

Muitas organizações, quando tentam mudar a direção do negócio e introduzir novas estratégias e processos, sem a ajuda de balanced scorecard, não conseguem alcançar uma consistência entre visão e ação. O Balanced Scorecard é um instrumental para implementar a estratégia e, ao mesmo tempo, permitir que ela evolua em resposta às mudanças nos ambientes tecnológico, de mercado e de concorrência da companhia. O Balanced Scorecard é mais que um exercício de mensuração, constituindo-se num sistema de gestão que incentiva o melhoramento nas questões críticas tais como produto, processo, cliente e desenvolvimento de

${ }^{38}$ Kaplan \& Norton (1996-a, pp.84-85). 
mercado ${ }^{39}$ : "Um programa de sucesso de Balanced Scorecard começa com o reconhecimento de que ele não é um projeto de 'medidas', é um projeto de mudança" 40.

Cumpre registrar que, em Kaplan \& Norton (2001), esses quatro processos gerenciais são denominados de quatro princípios. A essência é a mesma:

1) o processo de "tradução da visão" (translating the vision) passa a ser denominado de princípio de traduzir a estratégia em termos operacionais, que tem como resultado o desenho dos mapas estratégicos e dos Balanced Scorecards;

2) o processo de "comunicação e vinculação" (communicating and linking) passa a ser denominado de princípio de alinhar a organização à estratégia, que prescreve a geração de sinergias entre as especialidades funcionais e as unidades de negócio;

3) o processo de "planejamento" (business planning) passa a ser denominado de princípio de fazer com que a estratégia esteja incorporada no trabalho de todos,

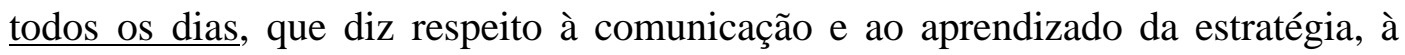
definição dos objetivos pessoais e a ligação do sistema de recompensa ao Balanced Scorecard (Balanced Paychecks); e,

4) o processo de "realimentação e aprendizado" (feedback and learning) passa a ser denominado de princípio de fazer da estratégia um processo contínuo, que diz respeito à ligação da estratégia ao processo orçamentário, à definição de reuniões gerenciais específicas para discutir a estratégia e ao processo de aprendizado e de adaptação da estratégia.

\footnotetext{
39 Kaplan \& Norton (1993, p.134).

40 Kaplan \& Norton (2001, p.16).
} 
Um quinto princípio é apresentado em Kaplan \& Norton (2001): $\underline{\text { mobilizar a mudança }}$ via executivos líderes. Isso é o reconhecimento de que ferramentas e processos, por si só, não garantem o sucesso do Balanced Scorecard.

Essa mobilização para a mudança, mediante a atuação firme dos executivos líderes, exige que eles intervenham em três momentos do projeto de mudança via Balanced Scorecard. No primeiro momento, seus esforços devem focar a mobilização da organização para a mudança, deixando claro à todos porque essa é necessária.

Em um segundo momento, quando a organização já estiver preparada para a mudança, os esforços desses líderes devem centrar no processo de governança para guiar a transição. Esse processo é o que define, demonstra e reforça os novos valores culturais para a organização.

Conforme esse processo evolui, os executivos líderes devem centrar seus esforços na consolidação dos novos valores em um novo sistema para gerir. O objetivo dessa fase é estabelecer, efetivamente, a ligação entre os processos de alocação de recursos e de recompensa com o Balanced Scorecard, culminando em um novo sistema gerencial: um sistema de gestão estratégica.

Em suma, esses processos ou princípios devem nortear a empresa para que ela possa entender a sua estratégia, traduzi-la em metas objetivas específicas e estabelecer medidas adequadas a elas para poder acompanhar o cumprimento daquela. 


\subsection{3 - AS MEDIDAS}

Em geral, uma infinidade de indicadores operacionais são criados para medir detalhes dos processos mas, poucos dão uma indicação do desempenho do conjunto ${ }^{41}$. Mais importante que o número de medidas é assegurar que o Balanced Scorecard seja a expressão de uma única estratégia ${ }^{42}$. O conjunto de medidas de avaliação de desempenho, no entanto, para ser facilmente utilizável, deve conter um número reduzido de medidas. Nele devem estar presentes apenas as medidas consideradas chaves para avaliar o cumprimento da estratégia ${ }^{43}$.

Com um reduzido número de medidas, os gestores podem focar a estratégia ao invés de se perderem na diversidade de indicadores possíveis. Mais ainda, essa recomendação para que os gestores selecionem um número limitado de indicadores críticos dentro de cada uma das quatro perspectivas, é uma maneira de forçá-los a manter o foco na visão estratégica ${ }^{44}$.

Os sistemas de informação são valiosos na medida em que podem dar suporte aos gestores quanto aos detalhamentos do Balanced Scorecard. A partir do relatório sucinto, pode-se derivar outras medidas ainda obedecendo o princípio do Balanced Scorecard de direcionadores de desempenho. Se surge um resultado inesperado em um dos indicadores do Balanced Scorecard, através do sistema de informação o gestor pode acessar os outros indicadores que devem explicar o resultado naquele, de forma cumulativa.

Assim, deve-se atentar para a diferença entre medidas de diagnóstico - aquelas que monitoram se o negócio permanece sob controle e indicam quando eventos excepcionais ocorrem exigindo atenção imediata e, medidas estratégicas - aquelas que definem a estratégia. As medidas de diagnóstico são necessárias mas não suficientes para o alcance dos

41 Kaplan \& Norton (1996-c, p.69) e Kaplan \& Norton (1993, p.143).

42 Kaplan \& Norton (1996-c, p.68).

43 Os autores (1996-c, p.68) constataram que a maioria das empresas tem trabalhado com 16 a 25 medidas.

44 Kaplan \& Norton (1993, p.134). 
objetivos de longo prazo. As organizações têm centenas, até milhares de medidas desse tipo. Mas elas não são os direcionadores de sucesso de competitividade.

O Balanced Scorecard não é substituto do sistema de mensuração do dia-a-dia da organização. Suas medidas são escolhidas para chamar a atenção dos gestores e dos funcionários para os fatores que se espera levar à mudança de desempenho desejada. $\mathrm{O}$ Balanced Scorecard centra na estratégia, na visão e não no controle. As medidas são estabelecidas para que as pessoas conduzam seus trabalhos em direção à visão geral, à estratégia.

\subsection{4 - AS PERSPECTIVAS}

As metas específicas de curto prazo e as medidas de desempenho devem ser divididas em, pelo menos, quatro perspectivas. São elas: 1) a financeira - mantendo as tradicionais medidas; 2) a do cliente; 3 ) a dos processos internos; e, 4) a do aprendizado e crescimento ${ }^{45}$.

\section{a) Financeira}

As medidas financeiras indicam se a empresa está obtendo êxito com as estratégias definidas, implementadas e executadas. Em geral, esse êxito é medido pela sua lucratividade, pelo seu crescimento e pelo incremento do valor para o acionista (shareholder value). Se os indicadores financeiros não mostram o esperado, podem haver problemas na execução, na implementação ou até mesmo na definição das estratégias.

Kaplan \& Norton (1996-c) identificaram três diferentes estágios do negócio, para os quais devem ser definidos conjuntos diferentes de medidas, pois os objetivos são também diferentes ${ }^{46}$ :

45 Nos artigos de 1992 até 1994, o termo utilizado foi Inovação e Aprendizado. A partir do primeiro artigo de 1996 (1996-a), os autores passam a chamar essa perspectiva de Aprendizado e Crescimento.

${ }^{46}$ Essa classificação simplória não é imutável. Há casos em que, mudanças tecnológicas, de regulamentação ou de estratégia permitiram que empresas em estágio maduro conseguissem voltar para o estágio de rápido 
- rápido crescimento (rapid growth)

- sustentação (sustain)

- colheita (harvest)

No estágio de rápido crescimento (rapid growth) os objetivos enfatizarão o crescimento das vendas, os novos mercados e novos consumidores, os novos produtos e novos serviços, os sistemas, a capacitação de funcionários; o estabelecimento de novos canais de marketing, vendas e distribuição, mantendo um nível adequado de gastos com desenvolvimento de produtos e processos.

No estágio de sustentação (sustain), os objetivos enfatizarão as medidas financeiras tradicionais, tais como retorno sobre capital investido, lucro operacional e margem bruta. Os investimentos em projetos, nesse estágio, serão avaliados por análises de padrões, fluxo de caixa descontado e orçamento de capital. Alguns podem incorporar o valor econômico agregado (EVA) e o incremento de valor para o acionista (shareholder value). Essas medidas representam o objetivo financeiro clássico: excelente retorno sobre o capital investido.

No estágio de colheita (harvest) a ênfase recairá sobre o fluxo de caixa. Qualquer investimento deverá prover retorno em caixa (cash pay back) certo e imediato, pois o objetivo não é maximizar o retorno sobre o investimento. Os gastos com pesquisa e desenvolvimento se escasseiam pois o ciclo de vida do negócio está em seu estágio final. Nesse caso, variáveis que possam comprometer o desfecho planejado do negócio (uma venda, uma liquidação, por exemplo), devem ser monitoradas. Essas variáveis podem ser o endividamento crescente, contaminação ambiental, insatisfação de clientes etc.

Os temas financeiros mais focados pelas empresas para realizar a estratégia, são: 
- crescimento e mix de receita;

- redução de custo e aumento de produtividade;

- utilização de ativos e estratégia de investimento;

que podem ser usados em qualquer um daqueles três estágios estratégicos antes referidos. As medidas financeiras, no entanto, é que serão diferentes de acordo com o caso.

Os objetivos financeiros de longo prazo devem nortear as ações relacionadas aos quatro diferentes processos. Assim, não se deve gerir os indicadores operacionais sem ter em conta os reflexos que geram nos indicadores financeiros.

\section{b) Clientes}

Querer ser uma empresa orientada para seus clientes ou ser a empresa fornecedora número um de seus clientes são objetivos comuns entre as empresas hoje em dia. A diferença está em como as empresas operacionalizam esse objetivo. Aí também reside a grande dificuldade das empresas: traduzir missões em medidas específicas que reflitam os fatores que realmente importam aos consumidores, para que essas orientem as ações. O Balanced Scorecard requer esse detalhamento ${ }^{47}$.

O uso do Balanced Scorecard explicita problemas que podem surgir com o uso de medidas genéricas, como mostra o caso do Metro Bank ${ }^{48}$. Ao formular as medidas para a perspectiva do consumidor, embora os 25 executivos seniores concordassem com os dizeres da estratégia ("prover serviço superior para os consumidores alvo"), cada um tinha uma idéia diferente de serviço superior e de quem eram os consumidores alvo.

\footnotetext{
${ }^{47}$ Kaplan \& Norton (1996-c).

48 Kaplan \& Norton (1996-a, p.78).
} 
Participação no mercado, por exemplo, é um objetivo comum entre as empresas. No entanto, é preciso identificar qual mercado, qual segmento. Uma medida genérica pode captar que a participação está aumentando mas não pode captar se é a participação do público alvo que está aumentando. Se o público alvo estiver corretamente mapeado (de acordo com a estratégia traçada) e o aumento na participação tenha sido uma excepcionalidade, problemas futuros certamente virão.

Uma das formas de aumentar ou manter a participação no mercado é manter os clientes atuais de cada segmento. Cabe a empresa identificá-los para poder medir a manutenção deles. Outra forma é atrair novos consumidores, que pode ser medida pelo número deles ou pelo total de vendas a eles em cada segmento. Qualquer das duas formas comuns entre as empresas tem como referencial a satisfação do cliente. E o cliente costuma se ater a atributos que podem ser divididos em quatro categorias: tempo, qualidade, desempenho e serviço e, custo $^{49}$.

Assim, para definir o Balanced Scorecard da empresa, é necessário articular as metas para tempo, qualidade, desempenho e serviço e, custo e traduzi-las em medidas específicas ${ }^{50}$.

O custo, de forma alguma, pode ser reduzido em detrimento dos outros fatores importantes para o cliente mas, não pode ser esquecido, até porque está diretamente relacionado com a rentabilidade. Todos esses valores são a chave para entender os direcionadores das medidas de satisfação, atração, retenção de clientes e participação de mercado e conta.

${ }^{49}$ Kaplan \& Norton (1992). Em Kaplan \& Norton (1996-c), os autores reduziram os atributos a três categorias apenas: atributos de serviço / produto; relacionamento com o cliente e imagem e reputação. Os atributos do produto e serviço dizem respeito a sua funcionalidade, seu preço e sua qualidade. A imagem e reputação permite a empresa a se projetar para seus clientes (posicionamento de marca, por exemplo). O relacionamento com o cliente diz respeito a entrega do produto ou serviço, incluindo tempo de resposta e de entrega e como o cliente se sente diante da experiência da compra.

50 Os autores (1996-c) sugerem para uma abordagem similar da perspectiva do cliente, REICHHELD, F. F. The loyalty effect. Boston, MA: Harvard Business School Press, 1996, chapter 8: The right measures, p.217-253. 
Aqui vale comentar uma curiosidade com a qual a ECI - Eletronic Circuits Inc. ${ }^{51}$ se deparou quanto aos conceitos 'confiável' e 'fornecimento responsável', ao estabelecer suas metas relacionadas a perspectiva do cliente. A ECI identificou que cada cliente tinha um conceito diferente de cada atributo. Para chegar a uma conclusão internamente, a ECI montou um banco de dados com as definições de cada um dos seus maiores clientes. A expectativa dos clientes quanto ao tempo considerado "em tempo" também variava. Uns se sentiam muito satisfeitos enquanto outros não. Assim, a ECI passou a enxergar o desempenho da empresa com os olhos dos consumidores.

Kaplan \& Norton (1996-c, p.60), no entanto, ressaltaram que recentes pesquisas ${ }^{52}$ mostram que a satisfação do cliente não pode ser super enfatizada, pois é necessária mas não suficiente para promover a lealdade dos consumidores, para atrair novos e para assegurar a rentabilidade - afinal, as empresas não querem apenas clientes felizes e satisfeitos mas, também rentáveis.

É preciso atentar para o fato de que a medição da rentabilidade pode apontar que um determinado segmento não é lucrativo. Clientes novos não rentáveis podem não ser problema na medida em que há um crescimento potencial do negócio. Clientes antigos não rentáveis podem comprometer o negócio e devem ser analisados sob a perspectiva de descontinuar a atividade para aquele segmento.

Uma ilustração, com o caso da Kenyon Stores ${ }^{53}$, ajudará a mostrar o ponto em tela.

${ }_{52}^{51}$ O nome da empresa de semicondutores é fictício (Kaplan \& Norton, 1992).

52 JONES, T. O. \& SASSER, W.E. (1995). Why satisfied customers defect. Harvard Business Review, Boston, Nov./Dec. 1995, pp.88-99.

${ }^{53}$ Kaplan \& Norton (1997). 
A Kenyon Stores, uma grande varejista de roupas, a partir dos objetivos financeiros de crescimento agressivo e manutenção das margens globais, estabeleceu o seguinte encadeamento estratégico para clientes: 1) aumentar sua participação no guarda-roupa das clientes-alvo; 2) conseguir esse aumento através da lealdade das clientes: as clientes devem visitar as lojas o ano todo, quaisquer que sejam suas necessidades relacionadas aos seus estilos de vida; 3) conseguir essa lealdade oferecendo mercadorias que definem as suas clientes, suas necessidades e a imagem a que aspiram, fazendo com que a marca satisfaça aos objetivos de estilo de vida e aspirações dessas clientes e, oferecendo uma experiência de compra perfeita (funcionários bem treinados, atenciosos, com boa aparência, gentis e lojas com boa aparência e estilo moderno); e, 4) trabalhar excepcionalmente bem para definir quem são as suas clientes e seus hábitos de compras.

A Kenyon Stores estabeleceu como metas: desenvolver uma imagem de marca sofisticada, fornecer mercadorias com excelente estilo, corte e qualidade a preços convidativos, serviço rápido e eficiente e excelente disponibilidade de produtos. Traduziu isso em objetivos organizados em três grupos: os que diziam respeito aos atributos dos produtos; à imagem; e, ao relacionamento com as clientes.

Quanto aos atributos dos produtos, a Kenyon Stores identificou três como atributos chaves: 1) preço, cujo objetivo era de não dar descontos, a ser medido pelo preço unitário médio e o número de transações por loja; 2) modernidade, cujo objetivo era de adequação às necessidades das clientes que deveria ser medido pelo crescimento anual de compras de "mercadorias estratégicas" e, pelo mark up (a melhoria do mark up indicaria a capacidade de sustentar boas margens de lucro com aquele estilo de roupas); e, 3) qualidade, cujo objetivo era garantir alta qualidade e consistência de corte em todos os estilos e categorias a ser medido pelo índice de troca de mercadorias. 
O objetivo em relação à marca e imagem era a de se tornar a marca dominante em nível nacional, entendendo claramente a cliente-alvo e se diferenciando na satisfação de suas necessidades. Esse objetivo foi medido pela participação de mercado em mercadorias-chave e pelo adicional de preço cobrado com a marca Kenyon.

Os objetivos identificados em relação ao relacionamento com as clientes-alvo foram a disponibilidade do produto (tamanho e cor) e a experiência de compra, medidos pelo controle de estoque de itens chaves e pesquisas com clientes e auditoras disfarçadas de clientes.

Assim, as medidas essenciais eram a lealdade das clientes-alvo e a satisfação delas. As medidas estratégicas eram o preço unitário médio e o número de transações por loja (para medir o objetivo de preços); a margem e a taxa de crescimento anual dos produtos (para medir o objetivo de estilo e desenho); o índice de troca de mercadorias (para medir o objetivo de qualidade); a participação de mercado do item chave e o preço especial para marcas de grife (para medir o objetivo quanto à marca e imagem); a falta em estoque de itens chaves (para medir o objetivo quanto à disponibilidade do produto); e, a pesquisa (para medir o objetivo quanto à experiência de compra).

\section{c) Processos Internos}

As necessidades dos clientes e as metas financeiras estabelecidas norteiam os processos internos que a empresa precisa ter para satisfazê-las ${ }^{54}$. As empresas precisam definir os processos e as competências que precisam superar e especificar medidas adequadas para avaliar se o objetivo está sendo atingido ${ }^{55}$.

\footnotetext{
${ }^{54}$ Em Kaplan \& Norton (1992), os autores não colocavam as metas financeiras como orientadoras dos processos internos. Na sequiência das perspectivas, a financeira vinha depois.

$55 \mathrm{Na}$ verdade, os autores reconhecem que por ser o Balanced Scorecard um instrumento para implantar a estratégia, ele deve se adequar a qualquer que seja a abordagem usada pela empresa para formulá-la: a partir da perspectiva do cliente para a perspectiva dos processos internos ou, ao contrário, a partir das capacitações internas para a perspectiva dos clientes. (Kaplan \& Norton, 1996-c, p. 58, nota 5).
} 
As abordagens tradicionais procuram monitorar e melhorar os processos existentes, mesmo quando incorporam medidas de qualidade e tempo. Já a abordagem do Balanced Scorecard, contempla também a avaliação de novos processos (os mais críticos para o sucesso da estratégia da organização) que precisam ser incorporados ${ }^{56}$.

A abordagem tradicional foca apenas a entrega de produtos e serviços para os consumidores atuais, controlando e melhorando as operações existentes - criação de valor de onda curta (short wave of value creation). A abordagem do Balanced Scorecard considera, adicionalmente, o processo de inovações, levando em conta produtos e serviços novos que atenderão os consumidores atuais e futuros - criação de valor de onda longa (long wave of value creation).

Para atingir metas referentes à duração do ciclo, a qualidade, produtividade e custo, por exemplo, os gestores devem traduzir metas globais referentes a essas características em metas locais, estabelecendo medidas capazes de orientar as ações dos empregados.

O recurso à ilustração com o exemplo da Kenyon Stores ${ }^{57}$, mais uma vez, ajudará a esclarecer o ponto em tela.

Os objetivos estabelecidos, pela Kenyon Stores, em clientes foram: desenvolver uma imagem de marca sofisticada, fornecer mercadorias com excelente estilo, corte e qualidade a preços convidativos e ainda um serviço rápido, eficiente além de uma excelente disponibilidade dos produtos. Para fazer cumprir essas metas, a Kenyon Stores identificou os seguintes processos críticos: a) gerenciamento da marca; b) liderança em estilo; c) liderança em fornecedores; d) disponibilidade de mercadorias; e) experiência de compra inesquecível.

\footnotetext{
56 Kaplan \& Norton (1996-c).

57 Kaplan \& Norton (1997).
} 
Para cada um dos processos, a Kenyon Stores definiu objetivos. Por exemplo, quanto ao gerenciamento da marca, ela identificou os seguintes objetivos: a) transformá-la em uma marca nacional com maior participação no guarda roupa das clientes alvo; b) ampliar o segmento de calças esportes e jeans como categoria dominante; c) ampliar a imagem de uma etiqueta própria bem sucedida para uma marca consolidada e facilmente identificada pelas clientes; d) desenvolver um bem sucedido programa de variedade de mercadorias e marketing.

E, para esse conjunto de objetivos, ela definiu as medidas que serviriam para monitorar o seu sucesso no cumprimento daqueles. Nesse caso, seriam: a) participação de mercado nas categorias selecionadas (calças esportes e jeans); b) reconhecimento de marca (pesquisas) e; c) novas contas abertas por ano.

O mesmo foi feito para cada um dos outros processos críticos.

\section{d) Aprendizado e Crescimento}

Como as chaves para o sucesso mudam ao longo do tempo, exigindo que as empresas melhorem, constantemente, seus produtos e seus processos e tenham a habilidade para introduzir produtos inteiramente novos, é necessário captar, mediante indicadores, se a empresa está se comportando adequadamente.

O aprendizado e o crescimento da organização vêm de três principais fontes: as pessoas, os sistemas e os procedimentos organizacionais. Os objetivos traçados através do Balanced Scorecard, em geral, acusam uma grande defasagem entre as capacitações das pessoas, dos sistemas e dos procedimentos e a requerida para alcançar os objetivos, promovendo o desempenho.

As empresas devem estabelecer as metas globais e traduzi-las em metas específicas. É possível estabelecer metas de melhoramento nos processos existentes ou focar-se no 
desenvolvimento de novos produtos ou processos. Depende do que a empresa considera como fator crítico para o seu sucesso.

Para eliminar essa defasagem é necessário capacitar os funcionários, intensificar a tecnologia e os sistemas de informação e alinhar os procedimentos e rotinas organizacionais. Tal como na perspectiva do cliente, as medidas baseadas nos funcionários incluem uma mistura de medidas genéricas - satisfação do funcionário, retenção, treinamento e habilidades e direcionadores específicos dessas medidas tais como índices detalhados de habilidades específicas requeridas pelo novo ambiente competitivo.

A capacitação dos sistemas de informação pode ser medida por avaliações em tempo real de informações sobre clientes e processos internos.

\subsection{5 - INTEGRAÇÃO ENTRE AS PERSPECTIVAS}

Como dito anteriormente, um balanced scorecard adequado deve contar a história da estratégia da unidade de negócio. O sistema de mensuração deve fazer as ligações (hipóteses) explícitas entre os objetivos (e medidas) nas várias perspectivas de tal sorte que possam ser geridas e validadas.

Os relacionamentos de causa e efeito devem permear todas as quatro perspectivas do Balanced Scorecard. Suponha, por exemplo que o scorecard financeiro escolhido tenha sido o valor econômico adicionado e que seu direcionador de desempenho seja manter ou aumentar as vendas a consumidores existentes. Assim, a lealdade do consumidor deve compor o scorecard na perspectiva do cliente como um direcionador do valor econômico adicionado. E o que a organização fará para conseguir a lealdade dos consumidores? Uma análise das preferências do consumidor pode revelar que o tempo de entrega é um fator muito importante. Espera-se então, que, com um melhor tempo de entrega, se estará aumentando a lealdade dos 
consumidores e, melhorando o desempenho financeiro. Com essa relação, o tempo de entrega também é incorporado ao scorecard na perspectiva do cliente ${ }^{58}$.

O processo continua através de perguntas sobre quais processos internos a organização deve superar para conseguir ter um excelente tempo de entrega. Pode-se detectar que é preciso diminuir o ciclo de produção e aumentar a qualidade do processo. Esses fatores deveriam, então, compor o scorecard na perspectiva dos processos internos.

E como a organização pode diminuir o ciclo de produção e aumentar a qualidade? Pode-se constatar que é preciso treinar o pessoal, que pode se constituir em uma medida na perspectiva de aprendizado e crescimento. O mapa de objetivos e medidas ficaria, então, como o exposto na Figura 2:

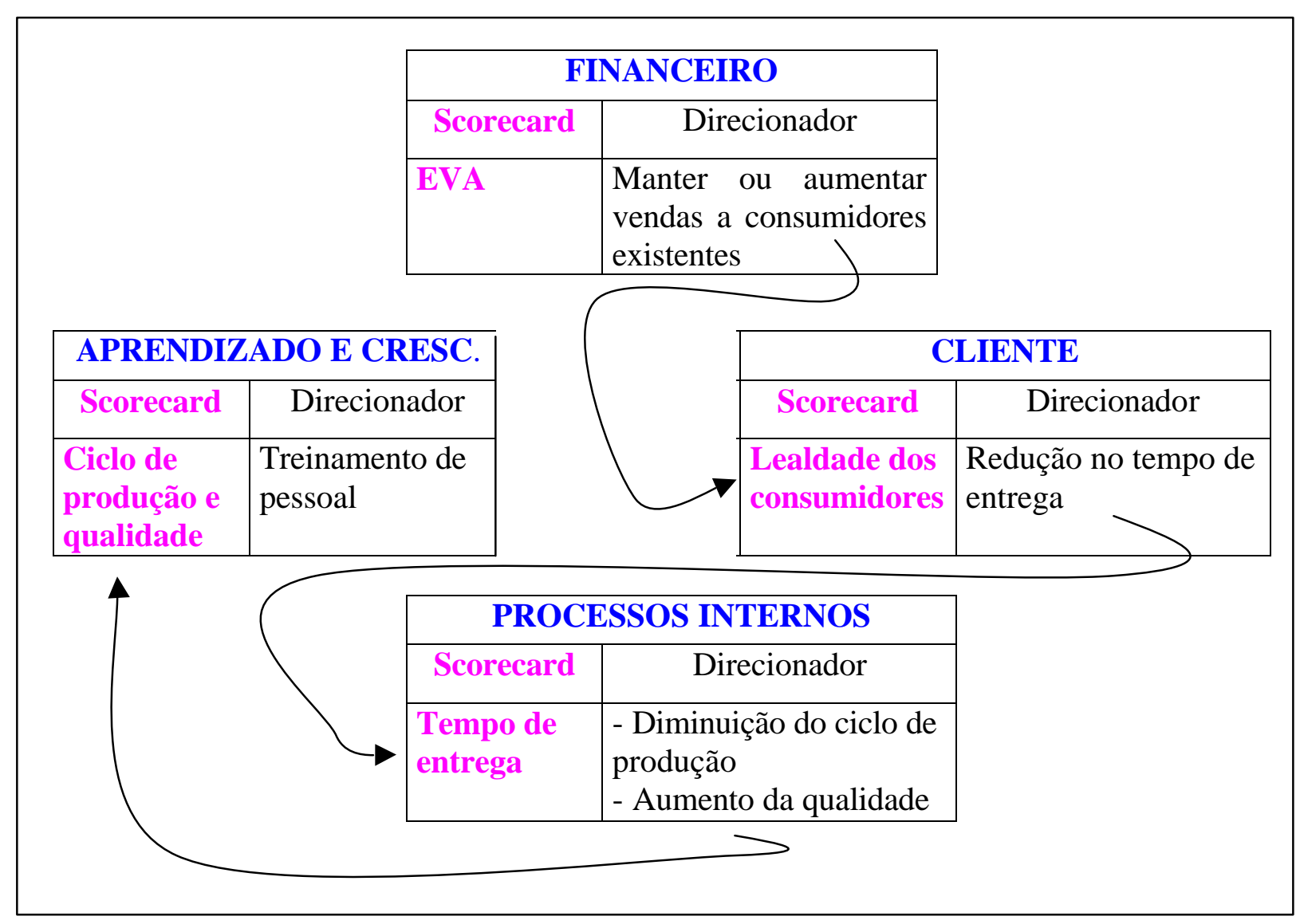

Figura 2: Ilustração de um Balanced Scorecard

58 Kaplan \& Norton (1996-c). 
Todo Balanced Scorecard usa certas medidas genéricas, comuns a várias estratégias, tais como participação no mercado, rentabilidade, satisfação do consumidor, retenção do consumidor e capacitação do pessoal. A essas medidas genéricas deram o nome de medidas de resultado essencial (core outcome measures).

Os direcionadores de desempenho (performance drivers) é que precisam ser aqueles que são únicos, aqueles que identificam aquela organização em particular. São os que direcionam a rentabilidade, o segmento de mercado escolhido, as proposições de valor entregue ao cliente naquele segmento de mercado e os processos internos e capacitações necessárias para se atingir os objetivos financeiros e aqueles em relação aos clientes. No exemplo anterior, os direcionadores de desempenho são o aumento ou manutenção das vendas aos consumidores existentes, a melhoria no tempo de entrega, a diminuição do ciclo de produção, o aumento de qualidade do produto e o treinamento do pessoal para enfrentar esses novos desafios.

Um bom balanced scorecard deve então combinar as medidas de resultado essencial e os direcionadores de desempenho. Os direcionadores é que indicarão como aqueles resultados essenciais deverão ser atingidos e se a estratégia está sendo implementada com sucesso. Os direcionadores sem as medidas de resultado essencial, por sua vez, permitem apenas que a unidade de negócio alcance metas de curto prazo sem indicar o que deverá ocorrer com a organização como um todo ou sequer com o desempenho financeiro. Assim, estabelecer como meta a melhoria do prazo de entrega sem saber que essa meta está relacionada com a conquista de lealdade do consumidor, que por sua vez, está relacionada com o aumento ou manutenção das vendas, não permite uma correta avaliação e checagem do cumprimento ou não da estratégia. 
A característica do Balanced Scorecard que permite misturar adequadamente as medidas de resultado essencial e os direcionadores de desempenho são os relacionamentos de causa e efeito que devem ser estabelecidos em sua construção. Afinal, são eles que permitem aos gestores estabelecer os objetivos quantitativos de curto prazo que refletem suas melhores previsões sobre a magnitude e velocidade de resposta entre as mudanças nos direcionadores de desempenho e as mudanças associadas em uma ou mais medidas de resultado.

No exemplo anterior, $\underline{s e}$ o pessoal receber treinamento específico, a empresa conseguirá reduzir o ciclo de produção e aumentar a qualidade do produto. $\underline{S e}$ o ciclo for reduzido e a qualidade melhorada, muitos retrabalhos serão suprimidos e o produto estará disponível mais cedo para ser entregue. $\underline{S e}$ o prazo de entrega for reduzido, o consumidor estará mais satisfeito. E, considerando que esse atributo é o mais importante para aquele consumidor, a empresa estará trabalhando para ganhar a lealdade desse consumidor e de outros novos, que, finalmente, manterão ou aumentarão as vendas. Esse encadeamento de ações, reflete as hipóteses de relacionamentos de causa e efeito que os gestores fazem a respeito do negócio em que trabalham.

Há trabalhos que exploram os relacionamentos de causação entre as ações. Kaplan \& Norton (1996-c) citaram Heskett (1994) ${ }^{59}$ para exemplificar as ligações existentes entre satisfação dos funcionários, satisfação dos clientes, lealdade dos clientes, participação no mercado e, apenas eventualmente, desempenho financeiro.

O Balanced Scorecard contempla essas ligações mas enfatiza a ligação de todas essas com o objetivo financeiro. Esse é que guia a definição dos objetivos nas outras perspectivas. 59 HESKETT, J., Jones, T. \& LOVEMAN, G. \& SASSER, E. \& SCHLESINGER, L.. Putting the service profit
chain to work. Harvard Business Review, Boston, Mar./Apr. 1994, pp.164-174. 
Com a proliferação de programas de mudanças em plena marcha na maioria das organizações hoje, é comum ter metas tais como qualidade, satisfação do cliente e inovação e implementar programas de gestão da qualidade total, reengenharia, entre outros. No entanto se, por um lado, essas metas e programas podem melhorar o desempenho da unidade de negócio, eles também podem se tornar um fim em si mesmo, falhando na ligação deles com o desempenho financeiro futuro. Muitas vezes, a frustração quanto ao resultado de tantos esforços despendidos é inevitável. Os problemas financeiros de alguns ganhadores do prêmio Baldridge ${ }^{60}$ são testemunhas de que é preciso fazer a ligação com os resultados econômicos 61.

O uso do Balanced Scorecard previne contra a subotimização dos recursos. Ao tratar as variáveis-chaves para a gestão de forma integrada, permite que os gestores analisem os efeitos de alcançar um melhoramento de uma área em detrimento de outra. Afinal, há várias formas de se atingir um mesmo objetivo. Se essas formas forem analisadas separadamente, por área, podem promover um melhoramento em determinada atividade a curto prazo mas comprometer o futuro do negócio.

A Figura 3 mostra como se dá a integração entre as perspectivas.

60 Malcom Baldridge é um prêmio nacional (americano) de qualidade, que inspirou o Prêmio Nacional de Qualidade do Brasil. Esses prêmios priorizam aspectos não financeiros, embora os financeiros façam parte deles.

61 Kaplan \& Norton (1996-c, p.67). 


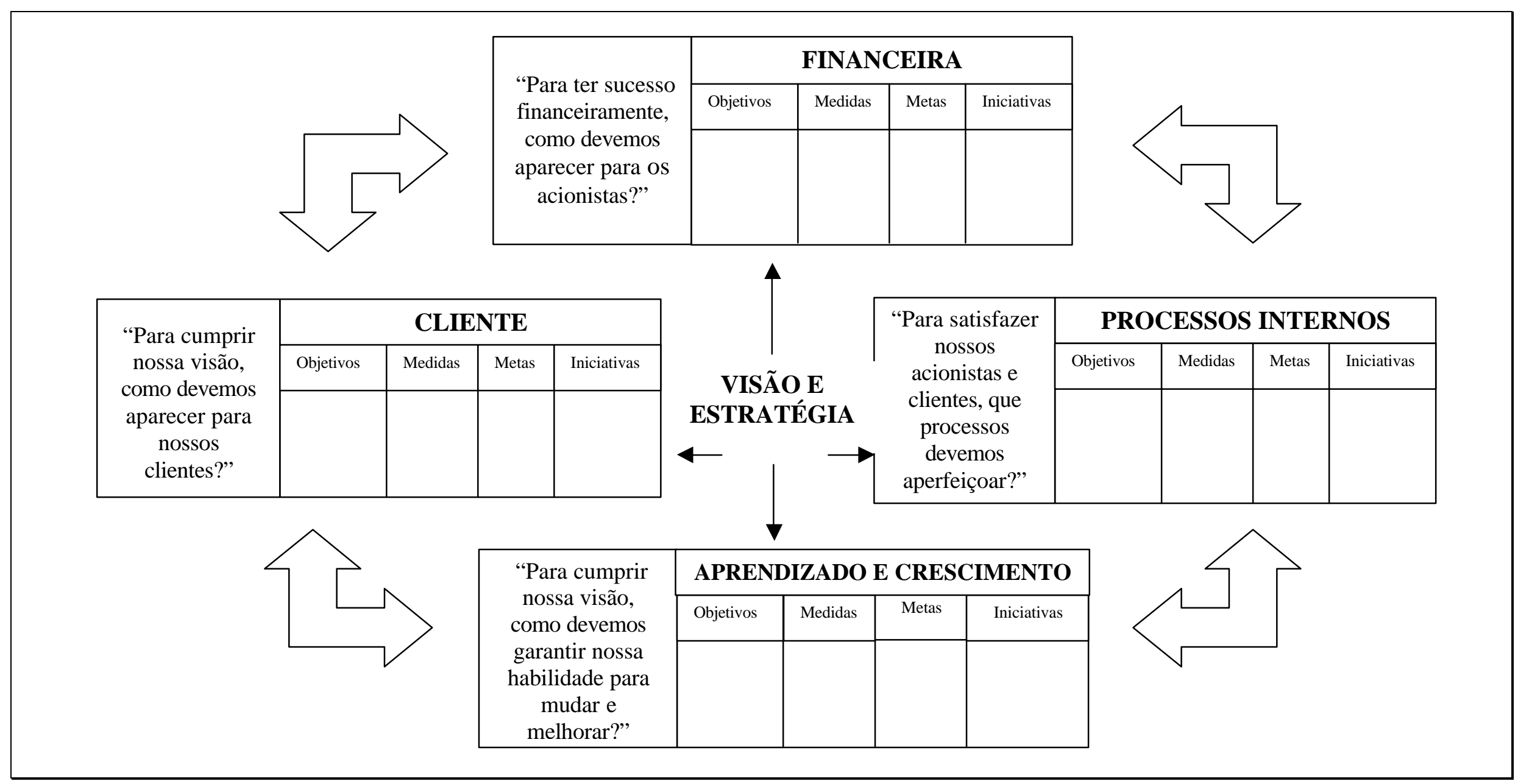

Fonte: Adaptação do quadro Translating Vision and Strategy: Four Perspectives (Kaplan \& Norton, 1996-a, p.76)

Figura 3: Tradução da Visão e Estratégia - Quatro Perspectivas 
Mais uma vez, o recurso ao caso da Kenyon Stores ${ }^{62}$ será útil para ilustrar essa integração:

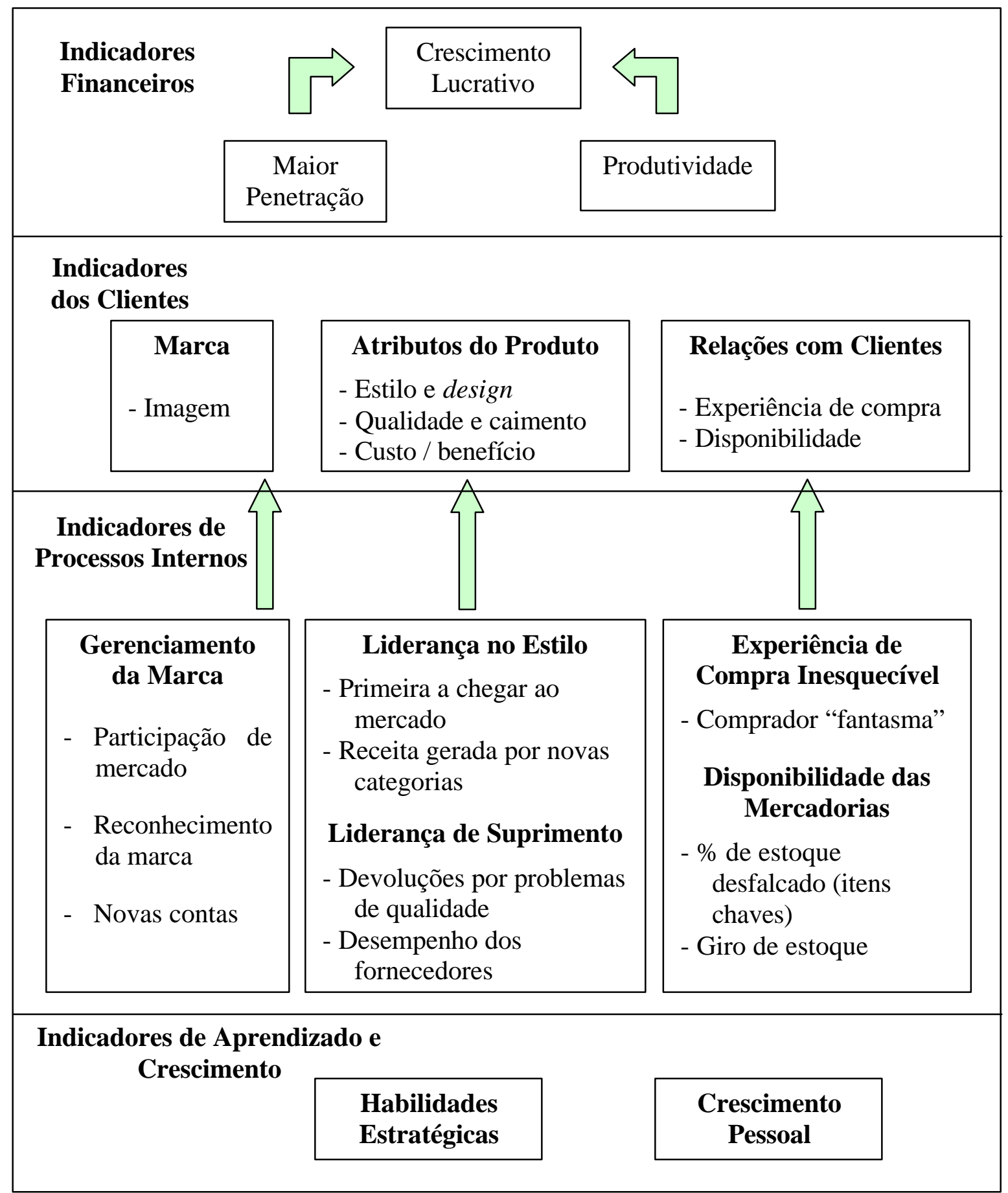

Figura 4: Integração dos Scorecards - Kenyon Stores

62 Kaplan \& Norton (1997). 


\section{2 - ESSÊNCIA}

O presente capítulo faz a transição entre a descrição contida no capítulo anterior e as análises contidas nos capítulos três e quatro. Para tanto, procura sintetizar as principais observações sobre o Balanced Scorecard, mostrando que ele se cristaliza num relatório único contendo um conjunto de indicadores de desempenho financeiro e não-financeiro, de curto e de longo prazo, de tendência e de ocorrência, interligados por relações de causa e efeito, definidos mediante processos gerenciais de desdobramento da estratégia em ações, que têm a capacidade de direcionar o desempenho, em todas as perspectivas de gestão, necessário para o cumprimento da estratégia (seção 3 - Arranjo). O Balanced Scorecard é um sistema de suporte às decisões (seção 2 - Classificação) necessárias para a gestão do cumprimento da estratégia (seção 1 - Foco). Dois exercícios hipotéticos procuram ilustrar esses pontos (seção 4 - Exemplos).

\section{1 - FOCO}

A palavra estratégia vem do grego strategos e significa "a arte do general" ${ }^{63}$. Com o avanço dos estudos sobre gestão, o conceito de estratégia ganha diversas abordagens, embora não perca o sentido original da palavra.

Estratégia, algumas vezes, é definida como o processo pelo qual os gerentes avaliam: 1) as oportunidades e ameaças presentes no ambiente externo; e, 2) a capacidade e os recursos internos para estabelecer metas e planos de ação para realizar essas metas ${ }^{64}$. O propósito último da estratégia é explorar ou gerar vantagens comparativas em relação aos concorrentes, fundamental para a sobrevivência das empresas.

\footnotetext{
63 Iudícibus (1999).

${ }^{64}$ Chandler Jr (1962) e Shank \& Govindarajan (1995).
} 
Estratégia, outras vezes, é definida como o resultado de um processo, que se consubstancia num plano, num conjunto de objetivos empresariais e de táticas para alcançálos (inclui-se aí os instrumentos competitivos escolhidos, as formas de financiamento a serem utilizadas, os pontos fortes que se explorará, os pontos fracos que se evitará, os produtos e serviços que serão ofertados a quais mercados e clientes entre outros) ${ }^{65}$.

Cabe registrar que a referência ao longo prazo, na estratégia, não pode ser entendida como ausência de data limite ${ }^{66}$. O que se pretende transmitir com o termo longo prazo é um prazo em que são manifestadas todas as conseqüências possíveis das decisões cruciais para a sobrevivência da empresa.

A estratégia guarda semelhanças com uma batalha pois, ambas, exigem que se produzam as condições mais favoráveis e se procure, com exatidão, o momento apropriado para atacar ou recuar, avaliando-se corretamente os limites do compromisso que se assume. Para isso, é preciso, em primeiro lugar, compreender com clareza o caráter particular de cada elemento da situação e depois, reestruturar esses elementos da maneira mais proveitosa. Para fazer todas essas análises, não basta a perspicácia pessoal do gestor, nem a intuição, nem o mero palpite; qualidades que, sozinhas, não podem servir de base para qualquer plano empresarial. "Só o equilibrado conjunto formado ao mesmo tempo pelo método analítico e pela elasticidade mental será capaz de conduzir a uma estratégia vitoriosa" ${ }^{67}$.

Independentemente de como os autores a definem (como um processo ou como o plano de ação ou diretrizes, resultados desse processo), todos concordam no que se refere aos

\footnotetext{
${ }^{65}$ Ansoff (1965), Andrews (1971), Marcovitch (1978), Yavitz \& Newman (1982), Mintzberg (1994), Maximiano (1995), Horngren \& Harrison \& Robinson (1996).

${ }_{66}$ Maximiano (1995) e Martins (1998).

${ }^{67}$ Ohmae (1985, p.33).
} 
requisitos básicos da estratégia: a coleta, a organização e a utilização de recursos de forma a ajudar a empresa a alcançar seus objetivos, tornando-a competitiva.

Há divergência quanto a sua definição mas não quanto a importância de se planejar a estratégia. $\mathrm{O}$ método analítico para realizar as análises e as escolhas necessárias para criar vantagem competitiva é o processo de planejamento estratégico.

O processo de planejamento estratégico permite dirimir algumas incertezas quanto ao rumo da empresa ${ }^{68}$. Quanto maior a incerteza, mais difícil é preparar metas satisfatórias que servirão de base para a avaliação de desempenho. E, se essas metas não refletirem as condições mais prováveis, não podem ser consideradas como compromissos sólidos e, as variações desfavoráveis não podem ser entendidas como indicadores consistentes de um fraco desempenho.

Para dirimir incertezas, o planejamento estratégico pressupõe a análise dos fatores culturais, econômicos, políticos, fiscais, ecológicos e até religiosos, conforme o caso ${ }^{69} 70$. Também é necessário analisar informações de algumas entidades do ambiente próximo, tais como fornecedores, clientes, consumidores, concorrentes etc. ${ }^{71}$.

Além das informações sobre o ambiente externo, é preciso levar em consideração alguns fatores relativos à capacidade interna de responder aos desafios. As informações internas, sobre as capacitações tecnológicas, técnicas - operacionais, de recursos humanos e financeiras, podem ser encontradas em vários sistemas da empresa, tais como o de custo padrão, o de orçamentos, o financeiro e o contábil.

\footnotetext{
68 Shank \& Govindarahan (1995, p.125).

${ }^{69}$ Custódio (1981) e Oliveira (1986).

70 Ohmae (1985) e Porter (1991) tratam das técnicas para se analisar os fatores ambientais para se definir a estratégia competitiva da empresa.

71 As informações relevantes dessas entidades que precisam ser conhecidas e monitoradas foram estruturadas por Rocha (1999).
} 
Esses sistemas, por sua vez, também foram objeto de estudo de muitos autores, pois há várias questões relacionadas às suas constituições e a forma como se interagem que influenciam nas suas capacidades de dar suporte adequado aos gestores.

É preciso haver uma integração conceitual e sistêmica entre o processo de gestão estratégica e os sistemas de padrões, de orçamentos e contábil. A integração conceitual se dá mediante as interações entre os modelos de decisão, de mensuração e de informação e, a integração sistêmica, evitando superposição e conflitos ${ }^{72}$.

Essa interação pode ser promovida pela contabilidade, que tem potencial para dar o suporte adequado aos vários tipos de decisão ${ }^{73}$. O sistema contábil não deve ser reduzido a um sistema de gestão estratégica de custos, pois custos são apenas uma parte das informações necessárias ao suporte à decisão ${ }^{74}$. Assim, um sistema de informação gerencial contábil mais abrangente, entre outras vantagens, evitaria redundâncias, dubiedades e, garantiria a integridade das informações.

A falta de integração entre os sistemas que dão suporte ao gestor pode induzir comportamentos, perspectivas e habilidades diferentes das efetivamente desejadas e necessárias para o cumprimento da estratégia ${ }^{75}$.

O planejamento estratégico, portanto, deve atentar para todos os fatores anteriormente apontados, para poder, efetivamente, gerar diretrizes para o planejamento operacional, que detalhará a combinação dos recursos internos tratados por esses sistemas de informações internas.

\footnotetext{
72 Nakagawa (1987).

73 Riccio (1989).

74 Iudícibus (1996).

75 Shank \& Govindarajan (1995, p. 116).
} 
É comum na literatura contábil e de administração o tratamento do planejamento estratégico separadamente do planejamento operacional. Simplificadamente, o planejamento estratégico trata das questões que afetam toda a empresa e, o planejamento operacional trata das questões que afetam apenas setores ou operações.

Não é incomum encontrar textos clássicos em que a ligação entre os dois tipos de planejamento fica apenas subentendida: passa-se direto da definição de estratégia para a apresentação de várias técnicas de gestão baseada em atividades (ABM) tais como o custeio $\mathrm{ABC}$, os sistemas de produção just in time, o orçamento do ciclo de vida do produto, custoalvo, custo kaizen e gestão total de qualidade ${ }^{76}$.

Existe, no entanto, uma vasta literatura enfatizando a importância de se fazer a ligação entre os dois planejamentos, entre a estratégia e a operação ${ }^{77}$. Afinal, não existem respostas únicas sobre as escolhas de projetos, alternativas de ação e, essa passagem da estratégia para o operacional não se dá, na prática, de forma tão natural como sugerida em outra parte da literatura.

Alguns trabalhos nessa linha de integração, entre o estratégico e o operacional, tiveram um destaque especial e consagraram certos termos na literatura:

1) alinhamento estratégico ${ }^{78}$ : integra a estratégia empresarial, a infra-estrutura organizacional e os processos gerenciais, a estratégia da tecnologia da informação (TI) e a infra-estrutura e os processos de tecnologia da informação;

\footnotetext{
76 Horngren \& Harrison \& Robinson (1996).

77 Skinner (1969), Banks \& Wheelwright (1979), Hayes \& Garvin (1982), Ohmae (1982), Yavitz \& Newman (1982), Porter (1985), Beischel \& Smith (1991), Kaplan \& Norton (1992) e Shank \& Govindarajan (1995).

78 Henderson \& Venkatraman (1992); Walton (1998).
} 
2) gestão estratégica de $\operatorname{custos}^{79}$ : tem como o foco a ligação do sistema de custo com a estratégia. Orienta a apuração dos custos de forma a suportar a análise dos fatores críticos de sucesso, embora admitam que esses são, em geral, melhor representados por dados não financeiros. Apesar desse reconhecimento, não apresenta uma forma sistemática para analisar essas informações não financeiras.

3) vantagem competitiva ${ }^{80}$ : enfatiza a importância da empresa se basear na vantagem competitiva que tem ou pode adquirir para estabelecer estratégias e seus desdobramentos em metas. A estratégia que não contemplar a busca ou manutenção de vantagem competitiva não é verdadeiramente uma estratégia.

Os autores que enfatizam a importância de se ligar a estratégia com a operação prescrevem que, a partir das informações sobre o ambiente interno e externo e da missão da empresa, deve-se identificar os fatores críticos de sucesso (para se ter vantagem competitiva), que muitas vezes não são facilmente mensuráveis por medidas financeiras.

O surgimento de medidas não financeiras é uma tentativa de reafirmar o princípio da empresa se dirigir pelas ações operacionais e não pelos resultados financeiros que são reflexos de decisões sobre ações realizadas no passado. E essa mudança realça a necessidade da empresa avaliar quais ações operacionais levarão ao resultado financeiro pretendido ${ }^{81}$. Para identificar essas ações e controlá-las os gestores precisam conhecer as causas e efeitos de custos e receitas. Só mediante o conhecimento das causas dos eventos é que se pode efetivamente tomar medidas corretivas ${ }^{82}$.

\footnotetext{
79 Shank \& Govindarajan (1995); Nakagawa (1996).

80 Porter (1992).

81 Shank \& Govindarajan (1995).

82 Murphy (1963).
} 
O Balanced Scorecard, conforme mostrado no capítulo anterior, surge na literatura com o propósito de identificar um conjunto apropriado de indicadores de desempenho estratégico e culmina em uma proposta de um sistema de gestão estratégica. Propõe a elaboração de um painel de indicadores financeiros e não financeiros relativos aos fatores críticos de sucesso, combinados e interligados por relações de causa e efeito, que indicam o cumprimento da estratégia da empresa.

A definição da estratégia, no entanto, não faz parte do escopo do Balanced Scorecard. O foco do Balanced Scorecard é o desdobramento da estratégia da empresa em ações de curto prazo e a gestão desse desdobramento. O foco do Balanced Scorecard, portanto, não abrange todo o tema estratégia.

\section{2 - CLASSIFICAÇÃO}

Kaplan \& Norton, inicialmente, definiram o Balanced Scorecard como um sistema de mensuração de desempenho e, posteriormente, como um sistema de gestão estratégica. Ambas as definições não indicam com precisão o escopo do Balanced Scorecard.

A inadequação da definição do Balanced Scorecard como um sistema de mensuração de desempenho pode ser mostrada com fundamento em Tonchia (2000). A literatura sobre sistema de mensuração de desempenho, segundo esse autor, dá maior atenção à prática do que ao arcabouço conceitual mas, é possível identificar três pontos básicos:

a) formalização das medidas e da medição, que consiste em responder as seguintes perguntas: o que deve ser medido e como deve ser medido;

b) integração desse sistema com os outros sistemas na empresa, principalmente os de planejamento e de controle de produção; 
c) uso do sistema para o controle das atividades, para a avaliação / participação dos funcionários e para comparações de desempenho (benchmarking)

A denominação sistema de mensuração de desempenho é inadequada porque o Balanced Scorecard não atende ao aspecto da formalização (que trata do como deve ser medido). Kaplan \& Norton apenas sugerem o uso do método de custeio ABC, sem qualquer discussão sobre a compatibilidade conceitual com o que procuram medir.

Outras duas considerações indicam como é inadequado dizer que o Balanced Scorecard é um sistema de mensuração de desempenho. Em primeiro lugar, porque o foco principal do Balanced Scorecard é o alinhamento estratégico necessário para que o desempenho possa ser gerido, que vai além de simplesmente vincular a mensuração com os sistemas de produção. Em segundo lugar, porque o Balanced Scorecard também trata dos processos gerenciais pelos quais se pode conseguir o alinhamento estratégico ${ }^{83}$.

A gestão estratégica é um processo de gestão cujo objetivo é assegurar a continuidade da empresa com vantagem competitiva. O planejamento estratégico é a fase desse processo que gera um conjunto de diretrizes estratégicas que nortearão o planejamento operacional. $\mathrm{O}$ processo de planejamento estratégico contempla as análises do ambiente externo (para identificar as ameaças e oportunidades) e do ambiente interno (para identificar os pontos fortes e fracos). O termo sistema de gestão estratégica como é conhecido na literatura, contempla a própria elaboração da estratégia e sua revisão ${ }^{84}$.

\footnotetext{
${ }^{83}$ Segundo Kaplan \& Norton (1996-c, p.68), o Balanced Scorecard é a tradução da estratégia das unidades de negócio em um conjunto de medidas interligadas que definem tanto os objetivos estratégicos quanto os mecanismos para alcançá-los e obter "feedback" deles.

${ }^{84}$ Rocha (1999).
} 
O termo gestão estratégica se confunde mesmo com o próprio processo de gestão pois, não há como gerir a estratégia separadamente do operacional. O termo gestão estratégica, portanto, refere-se ao planejamento, a execução e ao controle.

O Balanced Scorecard foca apenas o desdobramento da estratégia em ações, dentro da empresa. Os próprios autores fazem questão de enfatizar que não tratam da definição da estratégia: a estratégia definida é um dado para o Balanced Scorecard.

Quando Kaplan \& Norton usam o termo gestão estratégica, o estão usando no sentido estrito do termo: gerir o cumprimento da estratégia (já definida), ou seja, verificar se as ações estão conduzindo a empresa ao cumprimento da estratégia. A definição do Balanced Scorecard como um sistema de gestão estratégica também é inadequada.

Em suma, a definição, do Balanced Scorecard, como um sistema de mensuração de desempenho é inadequada, porque ele não trata do modelo de mensuração. Essa definição, além do mais, é insuficiente porque ele vai além da integração dos sistemas de informação da empresa. A definição, do Balanced Scorecard, como um sistema de gestão estratégica também é inadequada, porque ele trata apenas de parte do que se entende por gestão estratégica.

O Balanced Scorecard, adicionalmente, tem uma dimensão não contemplada nas duas definições anteriores. Ele, de imediato, fornece um critério para que o desempenho da empresa seja medido e gerido: deve-se medir e gerir o que indica o cumprimento da estratégia ("measures that drive performance"). O Balanced Scorecard, ao fornecer esse critério, conduz a uma reflexão posterior. 
A reflexão sobre o que conduz ao cumprimento da estratégia leva a uma reflexão sobre as amarrações necessárias entre as ações de vários níveis (operacional ao estratégico) e entre as várias áreas da empresa, agrupadas em várias dimensões ou perspectivas de gestão.

O Balanced Scorecard, portanto, fornece um critério para definir o que deve ser medido e gerido e fornece um modelo de gestão pelo qual a empresa pode definir o que deve ser medido e gerido. A literatura de tecnologia de informação contém uma classificação que expressa adequadamente essas características.

Em Keen \& Morton (1978) está exposto que, com a evolução da ciência da computação, os sistemas gerenciais foram classificados de acordo com o objeto (tarefa, problema ou decisão) e a solução tecnológica utilizada:

a) sistema de informação gerencial (MIS) - tem impacto sobre as tarefas estruturadas, cujos procedimentos operacionais padrões, regras de decisão e fluxos de informação podem ser predefinidos. O principal benefício é promover a eficiência e, o processo decisório do gestor é suportado por relatórios e pelo acesso aos dados;

b) pesquisa operacional ou ciência da gestão (OR/MS) - tem impacto sobre os problemas estruturados (mais que sobre tarefas) cujos objetivos, dados e restrições podem ser pré especificados. O principal benefício é gerar soluções melhores para determinados problemas e o processo decisório do gestor é suportado com recomendações e novas metodologias para tratar de problemas complexos;

c) sistema de suporte a decisão (DSS) - tem impacto sobre as decisões, que podem ser estruturadas o suficiente para receber suporte via computador, mas onde o julgamento do gestor é essencial. O benefício está em aumentar a abrangência e a 
capacidade dos processos de tomada de decisão com o intuito de promover a eficácia. A relevância para o gestor é a criação de uma ferramenta de suporte sob seu próprio controle, que não pretende automatizar o processo decisório, predefinir objetivos ou impor soluções.

As decisões que são suportadas pelo Balanced Scorecard não podem ser automatizadas, caso em que cairiam na primeira classificação (MIS - sistema de informação gerencial). Elas não podem ser pré estabelecidas e, portanto, não se encaixam na segunda classificação (OR/MS - pesquisa operacional ou ciência da gestão).

As decisões que são suportadas pelo Balanced Scorecard podem apenas ser ajudadas por um sistema de informações e, portanto, caem na terceira classificação: sistema de suporte à decisão (DSS). O sistema de suporte à decisão não se restringe à solução de informática. Sistema, nesse caso, é entendido como todos os processos, tecnológicos e não tecnológicos, necessários ao suporte à decisão. Esse escopo abrange o sistema de informações de medidas do Balanced Scorecard e seus processos gerenciais.

Um sistema de suporte à decisão sempre sofre alterações na medida em que os gestores avançam na compreensão do problema (já que esse pode ser apenas parcialmente estruturado), e de suas necessidades. O Balanced Scorecard também pressupõe alterações nas suas composições na medida em que os gestores vão compreendendo melhor o negócio da companhia e as relações de causa e efeito entre as ações.

O Balanced Scorecard é um sistema (no sentido amplo) de suporte à decisão, pois pretende reunir os elementos chaves para poder acompanhar o cumprimento da estratégica. A classificação adequada do Balanced Scorecard não está nos trabalhos de Kaplan \& Norton mas na literatura de informática. Tal classificação já é corrente nessa literatura. Os aplicativos 
comercializados de Balanced Scorecard fazem parte de aplicativos de Gestão de Desempenho Empresarial, que são classificados como sistema de suporte à decisão.

\section{3 - ARRANJO SISTÊMICO}

O Balanced Scorecard é uma proposta de como se definir, sistematicamente, o que deve ser medido e gerido (fatores chaves estratégicos), de forma a acompanhar o cumprimento da estratégia da empresa. A necessidade dessas informações serem definidas por quem gere e não por quem as gera, é inerente à lógica desse sistema. O Balanced Scorecard, enfatiza a necessidade do corpo diretivo estar em concordância sobre a estratégia da empresa e sobre seus desdobramentos em táticas e ações, pois o que deve ser medido e gerido é identificado a partir do desdobramento da estratégia à ação.

A estratégia tem que estar definida claramente, para que se possa chegar a um consenso sobre as metas essenciais ao cumprimento da estratégia. As ações / metas críticas ao seu cumprimento, são identificadas por meio de hipóteses sobre relacionamentos de causa e efeito entre elas. Essas metas essenciais / resultado esperado das ações críticas pressupõem o alcance de um conjunto de outras metas, que por sua vez, devem ser resultado de outras ações, num efeito cascata da estratégia à ação.

A partir daí, identifica-se os indicadores adequados para controlar se o resultado dessas ações são os esperados e, se esses resultados estão induzindo ao resultado de outras ações.

Assim, as informações a serem mensuradas devem obedecer a essa disposição de causa e efeito de forma que seja possível averiguar se aquele conjunto de metas está alcançando o resultado esperado, pois o alcance desse e de outros conjuntos de metas determinarão o alcance de outro conjunto, num efeito cascata, da operação à estratégia. 
A Figura 5 - Encadeamento da estratégia à ação e vice-versa, apresentado na página seguinte, ajuda a mostrar o que está sendo exposto.

Kaplan \& Norton sugerem que as empresas, por não explicitarem a estratégia do negócio, não têm conseguido algo imprescindível, que é solicitar as informações corretas. Se os gestores não têm a mesma concepção em suas mentes, todo o mecanismo de desdobramento da estratégia em ação fica prejudicado. Sem a clara idéia do objetivo estratégico da empresa como um todo, as diversas áreas irão trabalhar sem a integração de suas metas, necessária para o cumprimento da estratégia. 


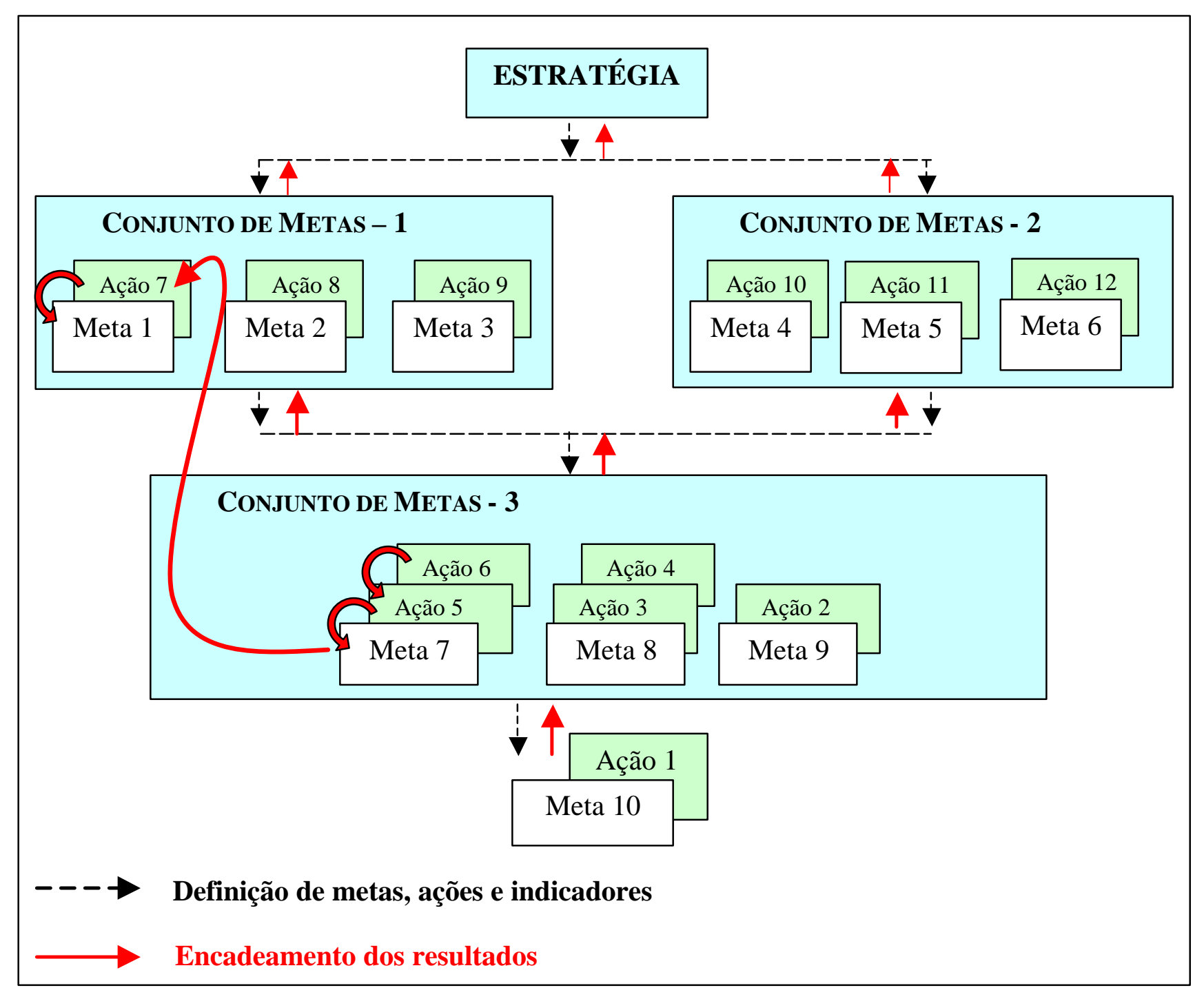

Figura 5: Encadeamento da Estratégia à Ação e Vice-Versa

O Balanced Scorecard enfatiza que a integração não deve ser somente vertical, da estratégia à ação, mas também lateral, entre as áreas, ou melhor, entre as perspectivas / dimensões da gestão.

O que se pretende alcançar financeiramente, deve orientar o que se pode e deve fazer em termos de produto e de mercado consumidor (o que fazer e para quem), que por sua vez, deve orientar as escolhas quanto aos modos de produção e disposição desses produtos / 
serviços, que por sua vez, devem orientar a decisão sobre a estrutura organizacional e administrativa e sobre a tecnologia de informação necessárias para dar suporte aos amplos processos de produção e venda.

Qualquer investimento na administração ou nos sistemas de informação que não atendam as necessidades prioritárias da produção e venda é desperdício, demonstra falta de foco da companhia.

A mesma observação pode ser feita quanto aos investimentos na produção e disposição dos produtos. Se eles não atenderem as necessidades prioritárias das áreas relacionadas aos clientes / consumidores, a empresa estará desperdiçando recursos.

A mesma observação se aplica, ainda, às áreas relacionadas aos clientes / consumidores. Deve-se definir claramente o que fazer e para quem, de forma que fique evidente o desperdício de recursos de qualquer ação fugindo desse escopo.

Em suma, dado que os recursos (financeiros, tecnológicos, físicos, capacitação humana etc.) são limitados, o Balanced Scorecard explicita o critério pelo qual esses recursos devem ser combinados e utilizados (assim como quais devem ser adquiridos, modificados ou dispensados): o desdobramento da estratégia em ações por mecanismos de causa e efeito pelos vários níveis hierárquicos da empresa e entre eles.

É esse mecanismo de amarração que define a disposição das informações. O Balanced Scorecard utiliza-se de poucos, mas fundamentais (críticos), indicadores de desempenho estratégico, capazes de expressar as iniciativas vitais que a empresa precisa focar para cumprir a sua estratégia. O Balanced Scorecard, "é como um prisma pelo qual todos os nossos investimentos são focados; ao invés de milhares de pontos de luz, temos um laser" ${ }^{85}$. As

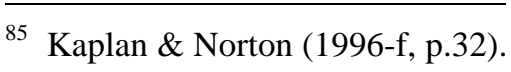


informações financeiras e não financeiras, de curto e de longo prazo, de tendência ou de ocorrência, devem ser escolhidas conforme a adequação para melhor expressar o alcance dos resultados esperados em todas as perspectivas de gestão. Quando se subordina aos resultados estratégicos esperados, traduzidos em metas financeiras, todas as ações da empresa, seja em relação aos seus clientes, aos seus produtos e serviços, aos seus processos internos ou à sua estrutura organizacional, faz-se necessário controlar o resultado das ações críticas em todas essas dimensões.

A disposição dos fatores críticos em cada uma das dimensões da gestão, permite se enxergar a empresa como um todo, sem ter que acessar e manipular um grande número de informações dispersas por essa e ainda ter que processá-las na mente ${ }^{86}$.

Assim, o Balanced Scorecard é um sistema para desdobrar a estratégia em ações e gerir o cumprimento da estratégia, que tem como requisito básico a necessidade de se ter claro qual é a estratégia da empresa. O arranjo sistêmico se caracteriza por processos gerenciais de desdobramento da estratégia de cima para baixo, pela identificação dos fatores chaves de desempenho organizados em quatro perspectivas de gestão, ligados entre si por relacionamentos de causa e efeito, e pela identificação dos indicadores e medidas que expressem adequadamente se o resultado das iniciativas estão produzindo os resultados esperados encadeados de forma a cumprir a estratégia.

86 Essa constatação é compartilhada por vários outros autores contemporâneos. Neely \& Austin (2000), por exemplo, dizem que na década de 80 medíamos coisas erradas e na década de 90, medimos coisas demais. 


\section{4 - EXEMPLOS ILUSTRATIVOS}

Dois exemplos hipotéticos, um mais simples, o caso de um hospital, e outro mais completo, o caso de uma instituição financeira, são úteis para sumariar o que foi apresentado neste capítulo.

\subsection{1 - EXEMPLO COM UM HOSPITAL ESPECIALIZADO}

Suponha que um hospital especializado tenha como estratégia se tornar o melhor centro de referência em algumas especialidades médicas.

Para fixar as metas relativas a cada perspectiva, é preciso avaliar as alternativas, em cada perspectiva, que mais contribuirão para o cumprimento da estratégia de tornar-se o melhor centro de referência em algumas especialidades médicas.

Pode-se avaliar, por exemplo, que, com relação à posição financeira (perspectiva: financeira), é fundamental otimizar a utilização do espaço e dos equipamentos e diversificar as fontes de receita de forma a garantir um maior volume de serviços faturados e um fluxo contínuo. Para isso, avalia-se que é preciso ampliar o atendimento (perspectiva: clientes), que pode ser por meio de um maior número de convênios de saúde e associações de classe e pelo maior atendimento à crianças e idosos.

Uma outra medida para se tornar o melhor centro de referência é garantir que o paciente sairá satisfeito com os serviços prestados, antes e após um procedimento cirúrgico. Para isso, o hospital avalia que a melhor alternativa (perspectiva: processos internos) é oferecer todos os procedimentos médicos de cada uma das especialidades, desde os mais simples até os de alta complexidade, além de todos os serviços de apoio às especialidades (apoio psicológico, fisioterapia, orientação nutricional etc.). 
A Figura 6 - Exemplo com um hospital especializado, mostrada a seguir, ajuda a ilustrar os pontos que se está procurando ressaltar.

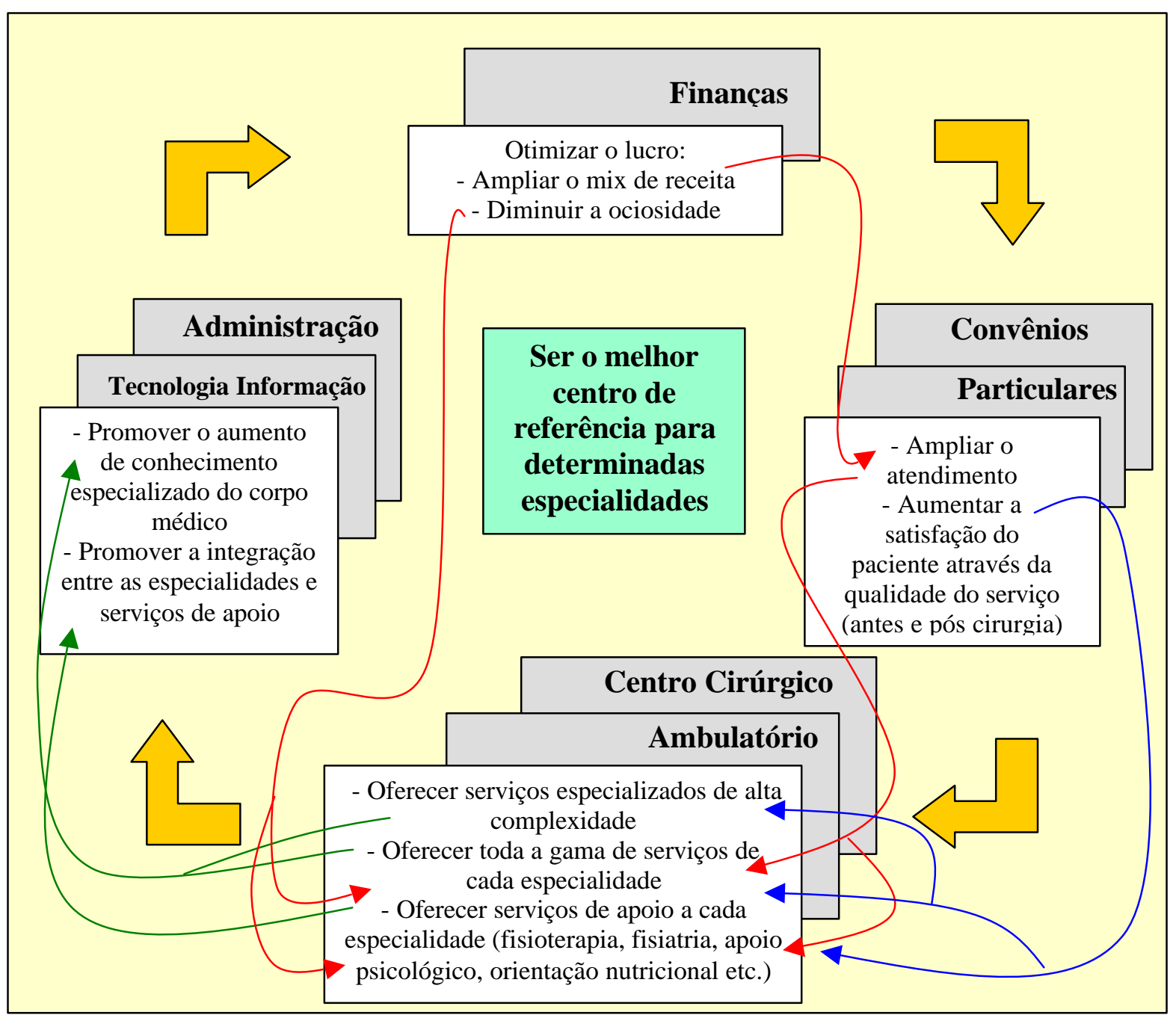

Figura 6: Exemplo com um Hospital Especializado

Assim, ao mesmo tempo em que se estaria otimizando a utilização do espaço e dos equipamentos se estaria mostrando aos pacientes que aquele centro entende do problema deles e conhece todas as dimensões do problema, fazendo com que os pacientes tenham cada vez mais confiança nos serviços prestados e promovam a construção da imagem desejada. 
Finalmente, para que o hospital possa oferecer todas os serviços de cada especialidade e os serviços de apoio, avalia-se (perspectiva: aprendizado e crescimento) que é necessário manter o corpo médico informado sobre as especialidades, incentivando pesquisas e vínculos com universidades de primeira linha, além de promover a integração entre as especialidades e os serviços de apoio, para que o hospital como um todo possa aprender mais e continuamente sobre todas as dimensões das especialidades de que trata, podendo oferecer os serviços mais adequados, o que, por sua vez, irá colaborar para que o hospital seja efetivamente o melhor centro de referência.

\subsection{2 - EXEMPLO COM UMA INSTITUIÇÃO FINANCEIRA}

Yoshikawa (1997) apresentou um modelo geral de acompanhamento de indicadores estratégicos, fazendo uso do Balanced Scorecard, para instituições financeiras. Aqui serão apresentados apenas os resultados de sua pesquisa para efeito de ilustração ${ }^{87}$.

87 As figuras a seguir foram extraídas de Yoshikawa (1997, p. 147 e 148). 


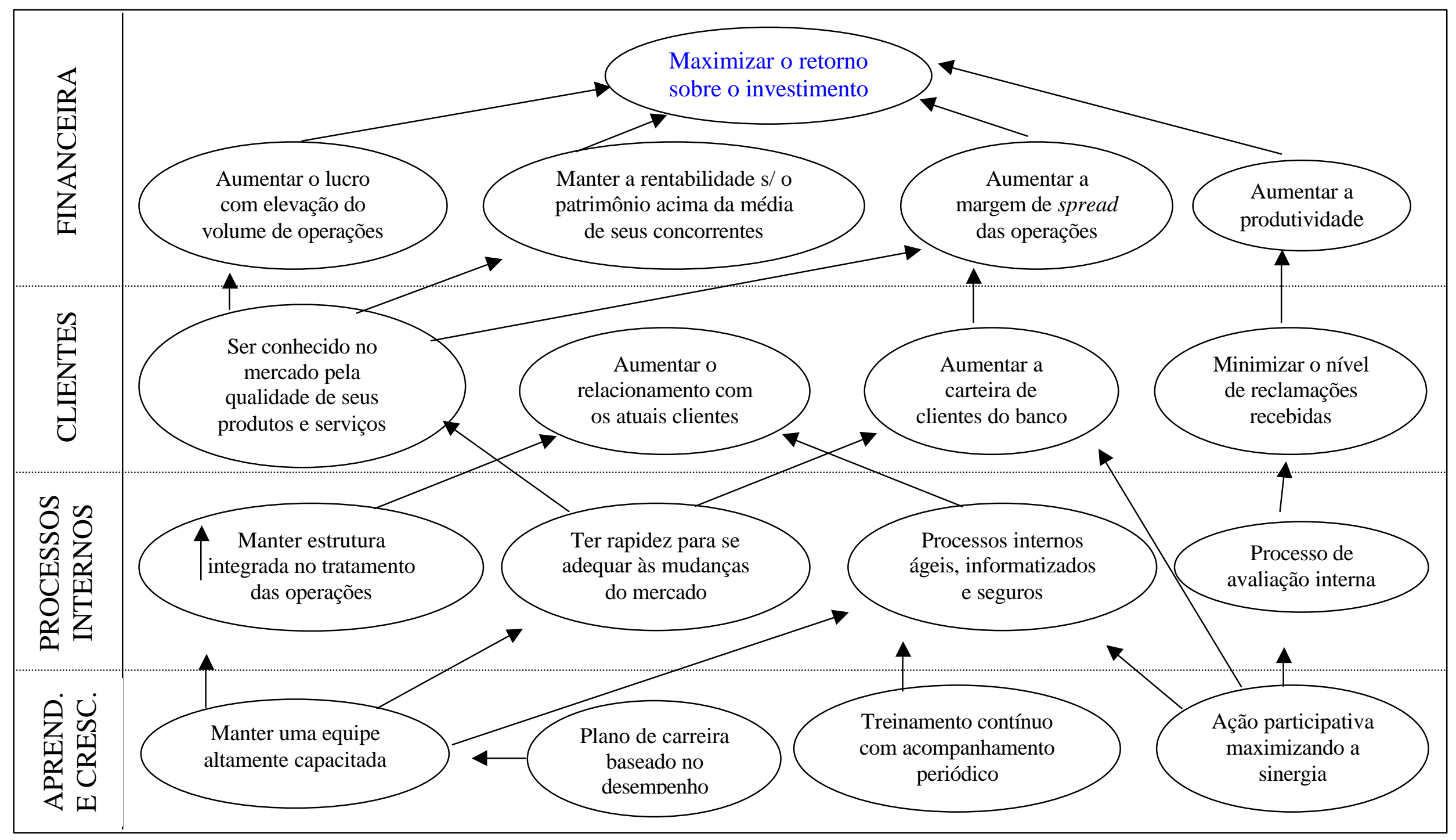

Figura 7: Relacionamento dos Objetivos Estratégicos 


\begin{tabular}{|c|c|c|}
\hline $\begin{array}{l}\text { PERSPECTIVA FINANCEIRA } \\
\text { - Maximizar o retorno sobre o investimento controlando o risco } \\
\text { das operações } \\
\text { - Aumentar o lucro com aumento do volume de operações } \\
\text { - Manter a rentabilidade sobre o PL acima da média de seus } \\
\text { concorrentes } \\
\text { - Aumentar a margem de spread } \\
\text { - Aumentar a produtividade }\end{array}$ & $\begin{array}{l}\text { - Posição de risco (exposição) } \\
\text { - Evolução do lucro líquido } \\
\text { - Evolução do vol. operações } \\
\text { - Retorno sobre PL } \\
\text { - Spread médio das operações } \\
\text { - Îndice de produtividade }\end{array}$ & $\begin{array}{l}\text { - Posições acima dos limites } \\
\text { estabelecidos } \\
\text { - Lucro líquido } \\
\text { - Volume de operações } \\
\text { - Lucro líquido / Patr. líquido } \\
\\
\text { - Taxa de aplicação - captação } \\
\text { - Var. Receita / Var. Despesa }\end{array}$ \\
\hline $\begin{array}{l}\text { PERSPECTIVA CLIENTES } \\
\text { - Ser conhecido no mercado pela qualidade de produtos e serviços } \\
\text { - Aumentar o relacionamento com os atuais clientes } \\
\text { - Aumentar a carteira de clientes do banco } \\
\text { - Minimizar o nível de reclamações recebidas }\end{array}$ & $\begin{array}{l}\text { - Qualidade de atendimento } \\
\text { - Evolução de operações e } \\
\text { volume médio / clientes } \\
\text { - Evoluçãa da qtde de clientes } \\
\text { - Volume de reclamações } \\
\text { recebidas }\end{array}$ & $\begin{array}{l}\text { - Pesquisa } \\
\text { - No de operações e volume / cliente } \\
\text { - Qtde de novos clientes /período } \\
\text { - No de chamadas recebidas }\end{array}$ \\
\hline $\begin{array}{l}\text { PERSPECTIVA APRENDIZADO E TREINAMENTO } \\
\text { - Manter uma equipe altamente capacitada } \\
\text { - Plano de carreira baseada no desempenho } \\
\text { - Treinamento contínuo com acompanhamento periódico } \\
\text { - Ação participativa maximizando a sinergia }\end{array}$ & $\begin{array}{l}\text { - Avaliação de desempenho } \\
\text { - Tempo médio por função } \\
\text { - Cursos efetuados } \\
\text { - \% de cumprimento de Metas } \\
\text { - Operações conjuntas }\end{array}$ & $\begin{array}{l}\text { - Pontuação média da avaliação } \\
\text { - Sistemas de avaliação de desemp. } \\
\text { - No de cursos efetuados } \\
\text { - \% cumprimento de medas } \\
\text { - Acomp. oper. conjuntas entre áreas }\end{array}$ \\
\hline
\end{tabular}

Figura 8: Relação entre os Objetivos Estratégicos, os Indicadores e as Medidas 


\section{3 - CONTRIBUIÇÃO TEÓRICA}

O presente capítulo contém o resultado da investigação sobre a contribuição do Balanced Scorecard para a teoria de contabilidade gerencial.

A seção imediatamente posterior a esta introdução contém a questão que se procurou responder e o critério utilizado para tal. A questão é se o Balanced Scorecard é, efetivamente, uma contribuição teórica ou se é mera cópia dissimulada de conhecimentos estabelecidos? Três critérios foram utilizados para o julgamento: 1) se ele trata de pontos nunca antes abordados; 2) se repensa conhecimentos estabelecidos, de maneira a aumentar a compreensão do tema (gestão); 3) se usa conhecimentos já estabelecidos para atender às exigências recentes.

A segunda seção mostra que as mensagens principais (necessidade de definir estratégias com precisão, de ligar estratégia à operação e de utilizar medidas não-financeiras para avaliar desempenho), o ferramental (direcionadores de desempenho, relacionamento de causa e efeito, processo hierárquico, perspectivas e processos gerenciais) e a técnica (gerir com o auxílio de indicadores de desempenho) não constituem qualquer novidade na literatura. A contribuição do Balanced Scorecard, portanto, não está em ter abordado pontos nunca antes tratados.

A terceira seção mostra que, Kaplan \& Norton, com o Balanced Scorecard, conseguiram fazer a articulação de conhecimentos antigos, numa maneira até então não enfatizada, contribuindo para um aumento da compreensão do tema do qual estavam tratando. Eles, ademais, conseguiram traduzir conceitos expressos na linguagem acadêmica em uma linguagem mais próxima do executivo, reduzindo o esforço de compreensão que o gestor 
precisa despender para implementar uma gestão estratégica e ajudando o gestor a compreender melhor o seu papel.

A quarta seção mostra que , Kaplan \& Norton, com o Balanced Scorecard, utilizaramse de conhecimentos já estabelecidos para atender às exigências do novo ambiente competitivo das empresas norte-americanas.

A quinta seção contém apenas a mensagem final do capítulo: o Balanced Scorecard é uma contribuição original à literatura de contabilidade gerencial, porque repensa conhecimentos já estabelecidos e os aplica para atender a exigências emergentes, aumentando a compreensão do tema vinculação entre a estratégia e a operação.

\section{1 - A COLOCAÇÃO DO PROBLEMA}

A presente seção expõe a motivação básica do estudo que resultou nesta dissertação: o Balanced Scorecard é efetivamente uma contribuição teórica original ou mera maneira de apresentar conhecimentos firmemente estabelecidos?

\subsection{1 - PLÁGIO OU CONTRIBUIÇÃo TEÓRICA?}

Kaplan (1994-b) afirmou que o Balanced Scorecard é uma inovação na teoria de contabilidade gerencial pois reúne "insights" simples mas vitais que não estavam claramente articulados na literatura existente. Alguns autores, no entanto, contestaram, alegando simples reprodução de velhos conhecimentos, com uma "roupagem" nova.

Allen (1999) sustentou que a leitura cuidadosa da definição de controle orçamentário revelaria que o Balanced Scorecard não apresenta qualquer novidade. A comprovação deste 
ponto está nos comentários que fez a respeito dos alegados benefícios produzidos pela implantação do Balanced Scorecard no Eurotúnel ${ }^{88}$.

Um primeiro benefício estaria na criação de uma árvore de objetivos traduzindo o objetivo do negócio como um todo em objetivos de departamentos e em metas individuais. Allen (1999) lembrou que, para isso, não era preciso implantar o Balanced Scorecard, bastava prestar a atenção na definição de controle orçamentário do Chartered Institute of Management Accountants - CIMA (UK): "estabelecimento de orçamentos relacionados às responsabilidades dos executivos...”.

Um segundo benefício estaria na montagem de um painel de instrumentos, por onde se pode acompanhar o que está acontecendo e compará-lo com o que era esperado. Allen (1999), mais uma vez, chamou a atenção para a definição de controle orçamentário, lembrando que a continuidade da sua leitura permitiria a constatação de que ela prescreve a contínua comparação entre os resultados orçados e os realizados.

Um terceiro benefício, produzido pela implantação do Balanced Scorecard no Eurotúnel, seria a possibilidade de se identificar as áreas que não estavam cumprindo suas metas, o motivo pelo qual isto estava ocorrendo e a proposição de soluções para o problema. Allen (1999), mais uma vez, rebateu, chamando a atenção que o uso adequado do controle orçamentário permitiria assegurar o cumprimento das políticas pelas ações individuais e servir de base para a revisão delas.

Allen (1999) afirmou que um contador competente: 1) sabe que cada negócio é único e tem suas especificidades; e, 2) sabe definir um processo de planejamento e orçamentação adequado ao negócio. Técnicas tais como o Balanced Scorecard, que se pretendem

\footnotetext{
${ }^{88}$ Túnel sob o Canal da Mancha, que liga a Inglaterra e a França.
} 
descobertas do que nunca foi perdido, são frutos da falta de compreensão do propósito e do ferramental da contabilidade gerencial. A frase final do referido texto está carregada de ironia pois, referindo-se aos que enfatizavam a importância do Balanced Scorecard, Allen (1999) comentou: "afinal, você não acha que estudou tudo aquilo só para passar nos exames, acha?"

O mesmo ponto, da ausência de originalidade, é sustentado por Malcolm (1999). Comentando o texto de Allen (1999), o referido autor, também recorrendo à ironia, afirma que os promotores dessas "descobertas", os autores do Balanced Scorecard, deveriam ficar agradecidos por deixar que eles pensem ter descoberto algo de novo. Duas seriam as razões pelas quais não se deveria desiludir os autores do Balanced Scorecard: 1) eles tiveram sucesso em fazer com que a mensagem da teoria fosse transmitida aos gestores, ao invés de ser diluída no caminho; 2) que os autores clássicos deveriam aprender a ser mais eficazes ao divulgar suas mensagens.

Em suma, o Balanced Scorecard é uma novidade teórica, trouxe alguma contribuição para a literatura de contabilidade gerencial ou é simplesmente um plágio?

\subsection{2 - SIGNIFICADO DE CONTRIBUIÇÃO TEÓRICA}

Na década de 1970, o texto de Cardoso \& Faletto (1970) sobre a teoria da dependência, que alcançou enorme notoriedade no mundo acadêmico e no mundo político, foi acusada de simples plágio de "velhas e boas" idéias presentes há muito tempo nas ciências sociais. Um dos autores dessa obra, Cardoso (1980), defendeu a referida obra sustentando que, nas ciências sociais, quase todos os conceitos utilizados podiam ser relacionados aos autores clássicos. As noções básicas das ciências sociais já tinham uma longa tradição. Havia, no entanto, contribuições teóricas verdadeiras, que podiam ser consideradas novas teorias. 
Uma teoria, para ser considerada nova, original, não precisava tratar de pontos nunca antes tratados. Uma teoria podia ser considerada nova, original, ter vitalidade intelectual, em duas situações: 1) quando repensava processos sociais antigos; e, 2) quando recorria a noções e a abordagens antigas para caracterizar processos sociais emergentes.

Iudícibus (1996), comentando a gestão estratégica de custos e sua interface com a contabilidade gerencial e a teoria da contabilidade, ressaltou a inadequação da crítica que sempre procurava diminuir a importância dos novos trabalhos em razão da sua vinculação com trabalhos antigos. O ponto chave é se esses novos trabalhos constituem um aperfeiçoamento dos antigos, contribuem para aumentar a compreensão do tema.

A junção de Cardoso (1980) com Iudícibus (1996) permite traçar a seguinte linha de investigação para avaliar se o Balanced Scorecard é um simples plágio ou se é uma nova teoria, uma contribuição teórica efetiva, se tem originalidade e vigor intelectual ${ }^{89}$ :

a) se ela tratou de pontos nunca antes abordados na literatura de contabilidade gerencial, aumentando a compreensão do tema e, portanto, aperfeiçoando a literatura de contabilidade gerencial;

b) se ela repensou temas tradicionais, aumentando a compreensão do tema e, consequentemente, aperfeiçoando a literatura de contabilidade gerencial;

c) se ela recorreu a abordagens tradicionais para caracterizar exigências gerenciais emergentes, aumentando a compreensão do tema e, por conseguinte, aperfeiçoando a literatura de contabilidade gerencial.

89 Soares (1996), em um debate sobre Globalização, usou o critério de Cardoso (1980) para compará-la com as teorias de Imperialismo. 


\section{2 - CRITÉRIO I: TRATAR DE NOVOS PONTOS}

A presente seção avalia o Balanced Scorecard à luz do primeiro critério acima estabelecido: é uma contribuição porque tratou de pontos nunca antes tratados? A conclusão desta seção é que, com base neste primeiro critério, o Balanced Scorecard não pode ser visto como uma contribuição original à teoria de contabilidade gerencial.

\subsection{1 - NOVAS MENSAGENS?}

As principais mensagens do Balanced Scorecard são: a) a necessidade de definição precisa das estratégias; b) a necessidade de que a operação seja vinculada à estratégia; e, c) a necessidade de que os sistemas de avaliação de desempenho e de gestão levem em consideração as medidas não-financeiras.

\section{a) Estabelecer estratégias definidas com precisão}

O Balanced Scorecard é um instrumento para desdobrar a estratégia em objetivos de curto e médio prazos, por entre os níveis organizacionais. Kaplan \& Norton, em vários artigos, ressaltaram que o Balanced Scorecard, mediante os quatro processos: 1) tradução da visão; 2) comunicação e vinculação; 3) planejamento; e, 4) realimentação e aprendizado), é um instrumento útil para implementar e gerenciar a estratégia definida pela empresa. A existência de uma estratégia bem definida é uma exigência do Balanced Scorecard.

Muito antes disso, Skinner (1969), chamou a atenção que, por desconhecimento e despreparo para as funções de gestão geral, as estratégias gerais eram definidas de maneiras pouco precisas. Os objetivos estratégicos mais comum eram: custos baixos, eficiência e produtividade. O estabelecimento de forma genérica, da estratégia corporativa, levava a que políticas e procedimentos, na produção, fossem definidos refletindo premissas erradas ou mal interpretadas. Por exemplo, a empresa, a todo momento, tem que fazer escolhas: o programa 
de computador deve minimizar o tempo de produção ou minimizar o estoque? Uma estratégia corporativa mal definida não serve para indicar o critério para a tomada de decisão.

A estratégia competitiva da organização, em cada instante do tempo, impõe uma certa demanda à sua função de produção, que deve ser desenhada para cumprir os planos estratégicos. A alta administração, no entanto, de maneira contumaz e inconsciente, não definia com precisão as estratégias e delegava, aos níveis gerenciais mais baixos, na área de produção, uma grande parcela das decisões de políticas básicas. O resultado eram decisões sobre equipamentos, plantas, pessoal e controles que retiravam a capacidade competitiva das empresas pois, predominava uma excessiva simplificação no conceito de boa gestão fabril, reduzindo-o a equipamentos modernos, informatização dos sistema de informações etc.

Porter (1985) reforçou esse ponto quando escreveu sobre vantagem competitiva, chamando a atenção de que muitas empresas estabelecem seus planos estratégicos como relações de ações sem uma clara articulação da vantagem competitiva que têm ou buscam conseguir e de que modo. Assim, muitos planos são construídos com base em projeções de custos e preços futuros que estão quase sempre erradas, e não em uma compreensão fundamental da estrutura industrial e da vantagem competitiva, que determinará a rentabilidade quaisquer que sejam os custos e preços reais.

Assim, as empresas, muitas vezes, confundem a estratégia com os meios para obtê-las (tais como os característicos das fases: construir, manter ou colher) ou mesmo com os efeitos da vantagem competitiva (como liderança no custo). A busca da liderança, por si só, não garante que a empresa consiga uma vantagem competitiva. Ela pode mesmo fazer com que a empresa perca a vantagem competitiva que tem. A definição de uma "estratégia" sem a compreensão do que consiste a capacidade competitiva da empresa pode levá-la à derrocada. 
O Balanced Scorecard, ao enfatizar a necessidade de uma definição precisa da estratégia, não trouxe qualquer novidade para a literatura de contabilidade gerencial.

\section{b) Ligar operação e estratégia}

O Balanced Scorecard, a partir de determinado momento, evoluiu para um sistema de alinhamento e gestão estratégica, atendendo à necessidade de se ligar a operação com a estratégia da empresa, de vincular os objetivos de curto com os objetivos de longo prazo.

Muito antes disso, Skinner (1969) salientou que a manufatura, após ser dominada por especialistas em engenharia, estava sendo dominada por especialistas em informática e, esse histórico era o responsável pelo modelo de gestão predominante, "tecnicista", incapaz de estabelecer a relação entre produção e estratégia.

Em razão da manufatura envolver cada vez mais variáveis sofisticadas e conhecimentos específicos, os gestores evitavam se envolver na política fabril, delegando decisões que não deveriam, perdendo a oportunidade de gerir a estratégia corporativa, causando danos às empresas que, muitas vezes, levam anos para serem superados.

Essa delegação indevida era fruto da predominância, no setor fabril, da falta de uma concepção geral da gestão. Imperava, então, a crença de que certos padrões técnicos eram suficientes para promover a eficiência e a boa gestão, independente do negócio. Acreditava-se que equipamentos modernos, atualização de métodos e procedimentos, informatização do sistema de informação etc. eram requisitos suficientes para se fazer uma boa gestão.

Esse tipo de gestão, "tecnicista", não levava em consideração um ponto fundamental: decisões fabris, que parecem rotineiras, freqüentemente, limitam as opções estratégicas. Skinner (1969) ainda ressaltou que mesmo as pequenas e sutis diferenças nas estratégias 
corporativas deviam estar refletidas nas políticas de produção mas, que a gestão "tecnicista", pelas características apontadas, não fazia essa ligação.

Banks \& Wheelwright (1979) também ressaltaram a necessidade de balancear objetivos de curto prazo com os objetivos de longo prazo e indicaram alguns passos para se fazer esse balanceamento. Hayes \& Garvin (1982) ressaltaram os problemas decorrentes de se guiar por objetivos de curto prazo, lembrando que as empresas não são constituídas apenas de ativos tangíveis e que os vínculos perdidos entre as pessoas e a organização acabam por dificultar a correção dos rumos da empresa, comprometendo ainda mais os resultados de longo prazo. Yavitz \& Newman (1982) fizeram uma série de considerações sobre a necessidade de alinhar as ações e quaisquer investimento à estratégia corporativa, tirando proveito da vantagem competitiva que a empresa tem ou pode ter com as novas ações. Nessa mesma linha, Porter (1985) destacou a importância de se ter como critério definitivo para tomada de decisões, a vantagem competitiva, que deve ser o foco de qualquer estratégia. Beischel \& Smith (1991) referiram-se à insatisfação comum com os números contábeis para suportarem a gestão da fábrica, ressaltando a necessidade de se ligar as medidas de chão de fábrica às medidas corporativas.

O Balanced Scorecard, ao enfatizar a necessidade da operação estar vinculada à estratégia também não trouxe qualquer novidade para a literatura de contabilidade gerencial.

\section{c) Adicionar medidas não financeiras}

Kaplan \& Norton (1992) chamaram a atenção que, para se gerir uma organização, é preciso levar em consideração tanto as medidas financeiras quanto as medidas não financeiras. A fundamentação para tal proposição foi apresentada em Kaplan (1983), onde foi afirmado que a contabilidade não tinha acompanhado adequadamente as mudanças no 
ambiente competitivo das organizações. O sistema contábil tradicional, em que os custos eram estimados com base em premissas de longos períodos de produção, de produtos padronizados, sem mudanças de características e de especificações, não era mais relevante no novo ambiente competitivo.

Muito antes disso, Skinner (1969), por exemplo, já tinha chamado a atenção que as variáveis custos, tempo, qualidade, restrições tecnológicas e satisfação do consumidor colocavam limites para a ação do gestor. Gerir exige o explícito reconhecimento não só de que essas variáveis são importantíssimas mas, a percepção de que, muitas vezes, existem contradições (trade-off) entre elas. A consideração de medidas financeiras e não-financeiras é uma exigência dos tempos modernos, onde prevalecem a maior variedade de produtos, períodos de produção mais curtos, mudanças aceleradas nas características dos produtos e elevada competição mercadológica.

Keegan \& Eiler \& Jones (1989) e Beischel \& Smith (1991), também enfatizaram a necessidade de que a avaliação de desempenho de uma organização fosse feita com base em medidas financeiras e não-financeiras.

O Balanced Scorecard, ao enfatizar que a avaliação de desempenho deveria recorrer a medidas financeiras e não-financeiras, não trouxe qualquer novidade para a literatura de contabilidade gerencial.

\subsection{2 - FERRAMENTAL AINDA NÃO UTILIZADO}

Serão abordados cinco pontos (ferramentais) que caracterizam o sistema de gestão estratégica do Balanced Scorecard: a) os direcionadores de desempenho; b) os relacionamentos de causa e efeito entre os objetivos definidos a partir da estratégia; c) o 
processo hierárquico do desdobramento da estratégia; d) as perspectivas de gestão a serem consideradas no desdobramento da estratégia; e, e) os processos para implantação e gerência.

\section{a) Direcionadores de desempenho}

O termo mais utilizado por Kaplan \& Norton é "direcionadores de desempenho" mas, no artigo de 1993, recorreram ao termo mais freqüentemente utilizado na literatura, "fatores chaves de sucesso", que melhor expressa o ponto que os autores pretendem ressaltar: fatores que indicam, com precisão, como o resultado esperado será alcançado.

Muito antes disso, Skinner (1969), disse que, para se ter uma política fabril vinculada à estratégia é preciso, em primeiro lugar, definir como competir no mercado. O passo seguinte é a definição das mudanças, na produção, necessárias para poder competir na forma desejada, analisando a melhor maneira de combinar as restrições econômicas, tecnológicas e de recursos. O detalhamento de objetivos específicos e mensuráveis para os diferentes níveis hierárquicos, que foram denominados de ingredientes críticos para o sucesso, devem ser definidos tendo em conta as: habilidades profissionais, a utilização dos equipamentos (existentes ou que serão adquiridos) e a rentabilidade esperada.

Ohmae (1985) ao escrever sobre a arte do raciocínio estratégico, também ressaltou a importância de se concentrar nos fatores chaves para o sucesso para guiar a alocação dos recursos internos de forma a conquistar vantagem estratégica sobre os concorrentes.

É certo que o Balanced Scorecard enfatizou os direcionadores e as medidas de desempenho, enquanto o mesmo não ocorreu com Skinner (1969). A ênfase nos direcionadores e nas medidas de desempenho, no entanto, está presente em Beischel \& Smith (1991). 
A diferença entre Beischel \& Smith (1991) e o Balanced Scorecard reduz-se a uma inversão na denominação: 1) o que Kaplan \& Norton chamaram de medidas de resultados essenciais, Beischel \& Smith denominaram fatores chaves de sucesso; 2) o que Kaplan \& Norton chamaram fatores chaves de sucesso ou de direcionadores de desempenho, Beischel \& Smith denominaram de scorecards (objetivos de curto prazo que indicam como os resultados maiores serão alcançados).

A utilização, pelo Balanced Scorecard, de direcionadores de desempenho não trouxe qualquer novidade para a literatura de contabilidade gerencial.

\section{b) Relacionamento de causa e efeito}

Uma das características do Balanced Scorecard é a definição de objetivos ligados por uma relação de causa e efeito.

Muito antes disso, Murphy (1963) destacou a importância dos gestores conhecerem as causas e efeitos de custos e receitas não só para controlar mas também para validar cursos de ação. Afinal, só através do conhecimento das causas e efeitos dos eventos é que se pode efetivamente tomar medidas corretivas.

Skinner (1969) ressaltou que a alta administração podia corrigir o desvirtuamento da gestão ligando, sistematicamente, a manufatura com a estratégia corporativa. Tal ligação sistemática podia ser obtida porque os objetivos, desde o nível operacional até o nível estratégico, eram ligados entre si mediante uma relação de causa e efeito. Assim, dado o objetivo de competir com o produto $\mathrm{X}$, no preço $\mathrm{Y}$, para o consumidor Z, usando certos canais de distribuição e formas de publicidade, define-se o que a empresa deve exigir da produção, em termos de custos, entregas, tempo de produção, níveis de qualidade e confiança para alcançar aquele objetivo. 
O mecanismo utilizado pelo Balanced Scorecard, para examinar os relacionamentos de causa e efeito, foi introduzido por Porter (1985), e é conhecido como cadeia de valor. A cadeia de valor surgiu para a análise sistemática de todas as atividades executadas por uma empresa e do modo como elas interagem para identificar a vantagem competitiva da empresa.

Fitzgerald \& Johnston \& Brignall \& Silvestro \& Voss (1991) fazem a distinção entre resultados e seus determinantes, ou seja, especificam relações de causa e efeito.

O "Linked Scorecards", desenvolvido por Beischel \& Smith (1991), é um instrumental para medir desempenho fabril, baseado em duas premissas básicas. Uma delas é que o desempenho fabril pode e deve ser ligado ao desempenho financeiro da companhia. A outra hipótese é que todas as medidas fabris - em todos os níveis organizacionais - estão interligadas por uma relação de causa e efeito. O acerto na definição dessa relação é que garante a constância de propósito entre os diferentes níveis e permite que todos os empregados possam atacar os problemas que resultam em desempenhos medíocres e continuar com as práticas que geram bons desempenhos.

O estabelecimento, pelo Balanced Scorecard, de relacionamentos de causa e efeito entre os objetivos definidos a partir da estratégia, não trouxe qualquer novidade para a literatura de contabilidade gerencial.

\section{c) Processo hierárquico ("top down")}

No Balanced Scorecard, os fatores chaves de sucesso são determinados por um processo hierárquico (top down) norteado pela missão e estratégia da organização; ou seja, a partir da missão e da estratégia são definidos objetivos para todos os níveis gerenciais, de cima para baixo, até o nível operacional, caraterizado por objetivos de curto prazo. 
Conforme já referido anteriormente, o mesmo procedimento hierárquico foi usado por Skinner (1969) em sua proposta para ligar a estratégia corporativa à operação. A sua abordagem começa com a estratégia da organização para definir as políticas de produção. É a definição prévia das políticas de produção que fornece a direção necessária para os especialistas técnicos, os engenheiros, os especialistas em recursos humanos e os especialistas em informática realizarem seus trabalhos.

Cross \& Lynch (1988/9) descreveram uma pirâmide de medidas que promove a integração dos desempenhos nas hierarquias da organização. Beischel and Smith (1991) também defenderam a utilização de um processo hierárquico para a definição dos scorecards e das medidas de desempenho. Cada medida de um certo nível gerencial deve estar ligada a uma ou mais medidas de um nível gerencial inferior, de forma que cada medida estratégica esteja ligada a várias outras medidas em um outro nível gerencial mais baixo até às medidas operacionais de chão de fábrica.

A proposta, pelo Balanced Scorecard, da utilização de um processo hierárquico (topdown) para o desdobramento da estratégia não constituía em uma novidade na literatura de contabilidade gerencial.

\section{d) Diferentes Perspectivas}

No Balanced Scorecard, partindo-se da estratégia da organização, estabelecem-se os objetivos e as medidas, levando-se em consideração pelo menos quatro perspectivas: 1) financeira - incluindo as tradicionais medidas; 2) cliente; 3) processos internos; e, 4) aprendizado e crescimento.

Beischel \& Smith (1991), trabalharam com cinco perspectivas: 1) qualidade do produto e do processo; 2) serviço de atendimento ao consumidor - externo e interno; 3) gestão 
de recursos; 4) custos e; 5) flexibilidade. Esses autores enfatizaram a necessidade de se estabelecer fatores críticos de sucesso e objetivos de curto prazo para essas dimensões.

Hubbard (1992) diz que, ainda em 1991, a IFMA (International Facility Management Association) apresentou um conjunto de indicadores comuns à gestão de plantas fabris, divididos em quatro categorias: 1) satisfação do cliente; 2) duração do ciclo de produção; 3) custos por unidade; 4) qualidade / acurácia / retrabalho.

Registre-se, no entanto, que o relatório do IFMA concluiu pela necessidade de se desenhar um indicador de desempenho para dar suporte ao nível acima do operacional. Essa necessidade foi atendida, posteriormente, pelo Balanced Scorecard.

Outros autores, embora não organizem a necessidade de se estabelecer objetivos e medidas a partir de perspectivas, indicam que as empresas e gestores, de uma forma ou de outra, têm procurado incorporar tais perspectivas em seus modelos de gestão. Eccles \& Pyburn (1992) constataram através de pesquisa e de consultoria que um grande número de empresas reconhecem a importância de se incluir, em seus sistemas de mensuração de desempenho, indicadores de qualidade, satisfação de clientes, inovações e outros resultados similares.

No entanto, reconhecer a importância deles é mais fácil que incorporá-los efetivamente. Muitas empresas tentaram incorporar tais perspectivas, não de uma forma integrada, mas mediantes programas específicos. Os programas de qualidade (TQM - Total Quality Management), gestão baseada em tempo, programas de serviço ao consumidor, Just in Time (JIT), reengenharia, entre outros, são tentativas de considerar tais perspectivas. 
De qualquer forma, não se pode dizer que, no desdobramento da estratégia, a consideração de diferentes perspectivas de gestão seja uma novidade na literatura de contabilidade gerencial.

\section{e) Processos gerenciais}

A ligação entre os objetivos estratégicos e as ações de curto prazo, no Balanced Scorecard, se dá mediante quatro processos gerenciais que devem ser geridos tanto separadamente quanto de forma combinada.

O primeiro desses processos é a tradução da visão e da estratégia da organização em um conjunto integrado de objetivos e medidas, que descreve os fatores chaves de sucesso de longo prazo. O segundo processo é a comunicação da estratégia e sua vinculação aos objetivos individuais e departamentais. $\mathrm{O}$ terceiro processo integra os planos financeiros com os corporativos, quando se estabelecem as prioridades das ações e a alocação dos recursos de acordo com elas. $\mathrm{O}$ quarto processo permite que a empresa modifique suas estratégias de forma a refletir o aprendizado em tempo real. $\mathrm{O}$ aprendizado permite validar a estratégia e saber como ela está sendo operacionalizada. O sistema dinâmico permite que se reafirme a convicção sobre a estratégia ou que se reconheça a necessidade de alterá-la (ou alterar as medidas) em função de novos conhecimentos sobre as condições de mercado ou capacidades internas (processo duplo de aprendizado).

A transformação do Balanced Scorecard, de um conjunto mais abrangente de medidas em um processo gerencial, segundo Allen (1999), não produz uma nova forma de gerenciamento. Essa transformação, ao contrário do que imaginam seus autores, é feita de maneira tal que constitui uma aproximação, do Balanced Scorecard, a uma técnica gerencial 
plenamente estabelecida e que é o "coração" da contabilidade gerencial: o controle orçamentário.

O que o Balanced Scorecard promete ajudar (entender melhor quais são os objetivos, facilitar a interpretação e a comunicação das estratégias, facilitar a constituição de equipes, facilitar a gestão das mudanças) são precisamente os benefícios de uma estrutura apropriada de controle orçamentário.

É certo que, na literatura, muitas vezes, o processo de gestão é dividido em três fases: planejamento, execução e controle. Isso induz a um tratamento estanque da gestão, como se fosse possível gerir a operação e a estratégia de forma separada. No entanto, a rigor, a gestão operacional não pode ser analisada independentemente da estratégica. E gerir a estratégia pressupõe controlar o que ocorre no operacional. A contabilidade gerencial, embora trate das fases de gestão separadamente, pressupõe a ligação entre elas na elaboração dos planejamentos e orçamentos.

Os processos gerenciais, que devem ser geridos tanto separadamente quanto de forma combinada, utilizados pelo Balanced Scorecard para fazerem a ligação entre os objetivos estratégicos e as ações de curto prazo, à rigor, não constituem uma novidade na literatura de contabilidade gerencial.

\subsection{3 - TÉCNICA AINDA NÃO UTILIZADA}

Lebas (1994) afirmou que a crise de 1929 mostrou a necessidade de se ter controles mais rígidos sobre os custos das empresas e, em função disso, a contabilidade gerencial, na França, dividiu-se em duas: contabilidade de custos e o Tableau de Bord. Houve, então, uma explícita separação na contabilidade gerencial. 
Malo (2000) informou que, embora o corpo de conhecimentos incorporado no Tableau de Bord tenha começado a ser desenvolvido no final do século passado e início deste século, o termo pelo qual ele ficou conhecido na literatura só foi utilizado, pela primeira vez, em 1932, por Satet \& Voraz (1946) ${ }^{90}$. Um termo utilizado para expressar a comparação que os referidos autores fizeram entre o gestor e o piloto de um avião, entre a gestão e a pilotagem de um avião.

\section{a) Tableau de Bord}

O objetivo do Tableau de Bord é, baseado em dados físicos, gerar informações para a tomada de decisão. Uma abordagem que expressa a predominância dos engenheiros nos postos-chaves. Resulta do entendimento que o desempenho das empresas podia ser melhorado com a compreensão das relações de causação entre ações e resultados. A pouca influência da contabilidade no processo gerencial, pode ser observada pelo fato de que o Tableau de Bord é referido como um instrumento de controle gerencial (contrôle de gestion) e não de contabilidade gerencial.

O Tableau de Bord considera a organização como um sistema. A visão e a missão da organização devem ser traduzidas em um conjunto de objetivos, a partir dos quais as unidades identificam seus fatores críticos de sucesso (direcionadores de ações - leviers d'action), que depois são traduzidos em indicadores chaves de desempenho, quantitativos.

Assim como um painel de instrumentos, o Tableau de Bord apresenta um conjunto mínimo de indicadores que ajudam ou guiam o gestor (o engenheiro ou o piloto, ou o operador de máquina ou negócio) a tomar decisões na pilotagem do negócio ou do centro de responsabilidade. Contém, prioritariamente, indicadores de desempenho controláveis pela

90 A primeira edição do texto de Satet \& Voraz aconteceu em 1932, conforme informação de Malo (2000). SATET R. \& VORAZ, C. Les graphiques moyen de direction de l'entreprise. $6^{\mathrm{a}}$ edition. Editions George 
unidade mas, também indicadores de desempenho que ajudem o gestor em suas tarefas e projetos interdependentes (entre áreas / unidades diferentes).

Os autores franceses destacam a necessidade desse painel (em qualquer nível gerencial) ser sucinto, pois sempre há o risco de sobrecarregá-lo com informações. O painel deve conter informações sobre o desempenho do passado recente, do presente e de benchmarking externo.

Assim, o negócio é representado por variáveis chaves (fatores críticos de sucesso) e medidas associadas a elas. Nem sempre é possível dispor, de imediato, de medidas físicas. É preciso, portanto, fazer um esforço para obtê-las, o mais rapidamente possível.

Essas variáveis e medidas são definidas tendo em conta a estrutura organizacional de delegações. Mediante o processo de "cascata", cada centro de responsabilidade tem o seu tableau de bord, maneira pela qual desdobra-se e implementa-se a estratégia. Em outras palavras, a partir de um documento de tableau de bord corporativo, definem-se outros documentos, tableaux de bord, que dão suporte às tomadas de decisões locais. A medição das variáveis torna visível o impacto das ações selecionadas em cada objetivo traçado.

O Tableau de Bord pode conter componentes de curto, médio e longo prazos ${ }^{91}$, desde que as áreas de ações críticas e, portanto, as variáveis críticas, exijam que as decisões sejam tomadas para diferentes horizontes de tempo. As informações financeiras contábeis são incluídas apenas para tomadas de decisão em níveis hierárquicos mais altos. A frequiência com que se elabora o Tableau de Bord não deriva de qualquer ciclo contábil, deriva sim, do ciclo de tomada de decisão.

Frére, 1946.

91 Não confundir a necessidade de se ter desempenhos passados e de benchmarking externos para se fazer comparações e avaliar a trajetória da empresa no cumprimento da missão com a necessidade de se ter componentes expressando a existência de ações de curto, médio e longo prazos. 
Os processos de elaboração e revisão do Tableau de Bord promovem o aprendizado, por parte da organização, e o reforço da missão corporativa.

Em suma, o Tableau de Bord, antes do Balanced Scorecard, recorreu a um conjunto mínimo de indicadores para ajudar o gestor a tomar decisões na pilotagem do negócio ou do centro de responsabilidade, a partir da estratégia. Como um conjunto integrado de conceitos, procedimentos e propósitos de gestão, o Tableau de Bord já havia sido desenvolvido e largamente aplicado em empresas francesas.

\subsection{4 - PONTOS JÁ ESTABELECIDOS NA LITERATURA}

Nenhum dos pontos que caracterizam o Balanced Scorecard constituem novidade na literatura especializada. Ele, portanto, não passa pelo primeiro critério para se definir a originalidade de uma teoria, para se afirmar que ela tem vigor intelectual, que ela contribui para o aperfeiçoamento da literatura, por contribuir para aumentar a compreensão do tema.

\section{3 - CRITÉRIO II: REPENSAR TEMAS ANTIGOS}

A presente seção avalia o Balanced Scorecard à luz do segundo critério antes estabelecido: repensar temas conhecidos de maneira a aumentar a compreensão do tema em tela. A conclusão desta seção é que, com base neste critério, o Balanced Scorecard pode ser considerado uma contribuição original à literatura de contabilidade gerencial.

\subsection{1 - BALANCED SCORECARD E TABLEAU DE BORD: DIFERENÇAS}

Strenger (1997) argumentou que a essência dos modelos é a mesma e alertou para que as pessoas não se confundam: qualquer que seja o nome usado, dashboard, painel de instrumentos ou scorecards, todos dão um suporte melhor ao gestor para tomar decisões relevantes. 
Epstein \& Manzoni (1997) (1998) também se enquadram entre os que não vêem diferença, do ponto de vista conceitual, entre o Balanced Scorecard e o Tableau de Bord. Eles ressaltam que alguns autores franceses consideram o Balanced Scorecard um caso especial do Tableau de Bord: o Balanced Scorecard é um Tableau de Bord em que quatro perspectivas são enfatizadas, bem definidas. Muitos autores franceses fazem referência ao Balanced Scorecard como um painel de instrumentos equilibrado (le tableau de bord équilibré) ou, mais comumente, como um painel de controle prospectivo (le tableau de bord prospectif).

A forma indevida com que as empresas têm aplicado o conceito do Tableau de Bord é que estaria fazendo com que se pensasse que ele era diferente do Balanced Scorecard. Ao invés de utilizá-lo adequadamente, as empresas costumam:

1) enfatizar as medidas financeiras, apesar da recomendação para se usar, predominantemente, medidas não financeiras;

2) usar um conjunto muito grande de indicadores, apesar da recomendação par se ter um conjunto reduzido;

3) usar indicadores já existentes, apesar da recomendação para se partir da visão e estratégia para o estabelecimento dos indicadores adequados;

4) escolher objetivos e metas internas, comparando-os com desempenho passado ou orçamento corrente, apesar da recomendação para se fazer a comparação com o benchmarking externo;

5) coletar as medidas, predominantemente, dentro da empresa, apesar da recomendação para se considerar dados externos, de clientes. 
6) usar o Tableau de Bord mais como um sistema de suporte a processos à distância e de administração por exceção, apesar da recomendação para utilizá-lo como um meio interativo de criar uma agenda para discussões e encontros.

Em outras palavras, o que Epstein \& Manzoni (1997) (1998) estavam sustentando é que a diferença entre o Tableau de Bord e o Balanced Scorecard não está no conceito mas, na forma indevida com que as empresas têm aplicado o Tableau de Bord. O problema do empobrecimento, da perda de potencialidade e utilidade do Tableau de Bord, está na forma de aplicação.

Mendonza \& Zrihen (1999) argumentaram que as diferenças entre o Balanced Scorecard e o Tableau de Bord são meras diferenças nos estilos de gestão entre os americanos e os franceses. Os americanos lidam com a decomposição da estratégia de forma normativa, de cima para baixo, sem se dar conta de como essa decomposição será feita por entre os níveis hierárquicos mais baixos. Os franceses, ao deixarem em aberto as dimensões de gestão, permitindo que os painéis (abaixo do painel corporativo) sejam elaborados de acordo com as necessidades do tomador de decisão, utilizam uma abordagem mais pragmática. As quatro perspectivas (financeira, clientes, processos internos, aprendizado e crescimento) são impostas de cima para baixo pelos norte-americanos, o que não ocorre com os franceses.

O Tableau de Bord foi desenvolvido com a ênfase em dar suporte à tomada de decisão e não para controlar o que cada gestor está fazendo. A hipótese básica é que os engenheiros sabem corretamente o que deve ser feito. Entende-se, assim, o porquê da ausência de definição das perspectivas e a diferença no número de relatórios.

O Balanced Scorecard, então, seria mais rígido do que o Tableau de Bord. A imposição das quatro perspectivas revelaria a falta de realismo/pragmatismo, um aspecto de 
rigidez, do Balanced Scorecard. Enquanto o Balanced Scorecard se constitui em apenas um relatório, o Tableau de Bord é desmembrado em vários, de acordo com o nível gerencial e de decisão. O uso de apenas um relatório faria o Balanced Scorecard mais adequado aos níveis hierárquicos mais elevados da organização, o que não ocorre com o Tableau de Bord.

Não é correto dizer, como o faz Strenger (1997), que não existe diferença entre o Balanced Scorecard e o Tableau de Bord. Não é correto dizer, como o fizeram Epstein \& Manzoni (1997) (1998), que a diferença entre o Balanced Scorecard e o Tableau de Bord é uma simples diferença na aplicação. Não é correto dizer, como o fizeram Mendonza \& Zrihen (1999), que a diferença entre o Balanced Scorecard e o Tableau de Bord é uma mera diferença de estilo de gestão.

As diferenças de ênfase, de estilo e de práticas expressam diferenças de concepções, de análise. Não se atua sem uma concepção prévia do que fazer. Os diferentes estilos de gestão constituem a aplicação prática de diferentes modelos teóricos. Diferenças de aplicação refletem, acima de tudo, diferenças na compreensão a respeito do instrumento que está sendo utilizado. Modelos com diferentes ênfases são diferentes modelos. Balanced Scorecard e Tableau de Bord, portanto, são, em termos teóricos, diferentes modelos que fundamentam diferentes práticas/estilos.

Existe uma contradição nos textos de Epstein \& Manzoni (1997) (1998). Se, de um lado, eles enfatizam a questão da diferença de estilo, mais rígido no caso norte-americano do que no caso francês, de outro lado, eles lembram que a definição de quatro perspectivas, no Balanced Scorecard, é mais uma indicação do que uma restrição. A eventual necessidade de uma quinta perspectiva tem que ser avaliada caso a caso. 
O que os referidos autores chamam de rigidez (a definição dessas quatro perspectivas), na realidade, é uma proteção contra o perigo de que a perspectiva financeira, por ter mais informações, por ser mais facilmente obtida, elimine totalmente as demais dimensões ou acabe por dominar o conjunto (como ocorreu com as empresas francesas).

A mesma linha de argumentação pode ser usada para justificar o número reduzido de indicadores que deve ser controlado por cada gestor. Os próprios Mendonza \& Zrihen (1999), aliás, ressaltaram que a diferença no número de relatórios não se restringe à dimensão quantitativa mas, tem importantes repercussões. Ao pressupor que, dando suporte aos gestores nos níveis operacionais, simultaneamente, se está dando suporte para toda a organização, o Tableau de Bord gera um problema para a gestão.

Ao querer tornar tudo visível, permitindo que um gestor de um certo nível hierárquico tenha acesso a parte dos indicadores dos seus subordinados, o Tableau de Bord aumenta, em muito, o número de informações. Isso, então, permite aos gestores selecionarem indicadores de desempenho, de seus subordinados, que ressaltem suas capacidades gerenciais, favorecendo-os na avaliação por parte dos seus superiores. O número excessivo de indicadores, então, pode resultar em relatórios "maquiados" (não confundir maquiagem com fraude).

Quatro perspectivas e número reduzido de indicadores expressam uma diferença conceitual importante: ênfase em se manter o foco da gestão. Collins \& Porras (1994) mostraram que as empresas que têm tido sucesso apresentam certas características em comum. Uma das principais características é preservar o que é essencial, manter o foco nos seus valores, na sua visão e estar disposta a mudar todo o resto: cultura, processos e objetivos; ou seja, submeter as ações à sua visão. Assim, consideram as quatro perspectivas e o relatório único, instrumentos importantes para essa objetividade. 
Em suma, existem diferenças importantes entre o Balanced Scorecard e o Tableau de Bord. Diferenças que não se resumem a meras questões de ênfase ou de estilo de gestão (mais ou menos rígida/democrática). Entre o Balanced Scorecard e o Tableau de Bord existem diferenças sobre como lidar, como implementar, os "velhos e bons conhecimentos".

\subsection{2 - BALANCED SCORECARD E TABLEAU DE BORD: PAINEL DE CONTROLE VERSUS SIMULADOR DE VÔO}

O Tableau de Bord, segundo Kaplan \& Norton (1997), é apenas um painel de indicadores críticos do sucesso organizacional e o Balanced Scorecard é um simulador de vôo.

A metáfora é adequada para explicar a diferença entre o Tableau de Bord e o Balanced Scorecard mas os motivos apontados por Kaplan \& Norton (1997) não são adequados.

Segundo Kaplan e Norton (1997), o Balanced Scorecard pode ser comparado a um simulador de vôo porque incorpora um conjunto complexo de relações de causa e efeito entre as variáveis críticas, incluindo indicadores de ocorrências, de tendências e ciclos de retroalimentação, que descrevem a trajetória, o plano de vôo/a estratégia da organização.

A explicação de Kaplan \& Norton (1997) está equivocada porque o estabelecimento de variáveis críticas e indicadores, mediante relações de causa e efeito, de forma a descrever a trajetória do que se deve fazer, do que se deve alcançar pelo meio do caminho para cumprir com a estratégia estabelecida, e ainda, de ter um ciclo de retroalimentação, conforme ressaltado por Gray \& Pesqueux (1993), é um procedimento também utilizado no Tableau de Bord.

O argumento apropriado para validar a semelhança entre o Balanced Scorecard e um simulador de vôo, está na definição das quatro dimensões que fazem com que, a cada 
momento, estejam presentes todo os condicionantes da estratégia/vôo. O mesmo não acontece com o Tableau de Bord porque a falta da "amarração" proporcionada pelas quatro dimensões, permite que o gestor/piloto se perca, focando parte das condições/dimensões do vôo/estratégia.

Qual, então, terá sido o motivo que levou Kaplan \& Norton (1997) a fundamentarem erroneamente sua proposição (correta)? A combinação de Epstein \& Manzoni (1997) (1998) com Alan (1995) permite levantar uma hipótese sobre a fonte desse erro.

Epstein \& Manzoni (1997) (1998) mostraram a forma indevida com que as empresas têm aplicado o Tableau de Bord. Alan (1995) afirmou que a contabilidade financeira desenvolvida na França está bem documentada em língua inglesa mas, o mesmo não ocorre com os conceitos e práticas da contabilidade gerencial. Duas razões são apontadas. Uma delas é o fato da França não ter um órgão representativo da comunidade contábil como ocorre na Inglaterra, que tem o CIMA (Chartered Institute of Management Accounting). A outra razão está no fato de não se ter, na França, uma publicação correspondente ao Management Accounting, que promove a disseminação e discussão de idéias e técnicas sobre o assunto gerencial. Apenas em Setembro de 1992 o jornal orientado para a profissão contábil, na França, La Revue Française de Comptabilité, introduziu uma seção sobre contabilidade gerencial.

Segue-se, então, que, em razão da dificuldade de acesso à literatura de contabilidade gerencial francesa, é possível que Kaplan e Norton (1997) não tenham fundamentado suas observações relativas ao Tableau de Bord no conceito e sim nas aplicações (indevidas). 


\subsection{3 - REPENSAR TEMAS ANTIGOS}

A mensagem do Balanced Scorecard é que, para gerir nos tempos modernos, é preciso: 1) analisar também medidas não financeiras; 2) estabelecer objetivos e definir ações de forma vinculada à estratégia; e, 3) definir a estratégia com precisão, evitando definições vagas, das quais não fosse possível depreender direcionamentos para o estabelecimento dos objetivos de curto prazo e das ações. Essa mensagem era compartilhada ou já havia sido explicitada por outros autores de língua inglesa.

O Balanced Scorecard usa técnicas já divulgadas anteriormente na literatura: definir direcionadores de desempenho (ou fatores chaves de sucesso), mediante relacionamentos de causa e efeito, a partir da estratégia, por um processo hierárquico. As perspectivas, em si, como dimensões a serem exploradas na gestão (financeira, clientes, processos internos e aprendizado e crescimento) não constituíram novidade. Outros modelos e técnicas tentaram explorá-las, combinadas ou separadamente.

Os processos gerenciais que devem ser implementados com o Balanced Scorecard, na essência, assemelham-se aos processos de planejamento e de orçamentação, que, a rigor, deveriam ser praticados.

Balanced Scorecard e Tableau de Bord têm inúmeras semelhanças quanto ao ponto de partida, aos conceitos, procedimentos e propósitos. Ambos procuram traduzir a estratégia em objetivos e indicadores (financeiros e não financeiros) por entre os níveis organizacionais, mediante um processo hierárquico (top down). Ambos prescrevem a definição de fatores críticos de sucesso e que a ligação entre os desempenhos desejados e as ações a serem definidas, seja feita por relações de causa e efeito. Ambos trataram dos mesmos pontos. 
Não se deduza, daí, que o Balanced Scorecard nada acrescenta à literatura de contabilidade gerencial, que ele é, mera reapresentação de pontos sobejamente conhecidos, o que significa dizer que ele é um simples plágio.

A novidade do Balanced Scorecard está no tratamento peculiar de conhecimentos antigos. Kaplan \& Norton, ao longo das obras publicadas sobre o assunto (de 1992-2001) repensam processos gerenciais antigos, exploram as interligações existentes entre eles e decodificam a complexidade delas em uma linguagem mais simples e integrada. O próprio Kaplan (1994-b) apontou para essa direção quando afirmou que o Balanced Scorecard reúne pontos simples mas vitais que não estavam articulados claramente na literatura.

O primeiro ponto que merece ser chamado a atenção como uma novidade do Balanced Scorecard é a decodificação dos complexos processos de escolhas aos quais os gestores estão sujeitos, consubstanciado na definição das quatro perspectivas de gestão. Vale ressaltar que, o uso de outras perspectivas não é novidade, mas as quatro perspectivas em questão sim. A diferença está em que as quatro perspectivas não são definidas aleatoriamente, são definidas a partir de uma concepção de gestão. A partir da estratégia, definem-se os objetivos financeiros, que irão orientar as escolhas relacionadas aos clientes, que por sua vez, irão orientar a identificação das mudanças necessárias quanto aos processos internos que, por sua vez, irão indicar as mudanças em relação à capacitação de recursos humanos e ao sistema de informação (que darão suporte para as mudanças nas outras perspectivas). As quatro perspectivas do Balanced Scorecard, expressam como a produção do resultado final se dá pela empresa e; consequentemente, expressam o encadeamento de decisões que conduzem ao cumprimento da estratégia.

Ao invés de orientar, genericamente, as empresas a escolherem aqueles objetivos e medidas que direcionam a estratégia (como faz o Tableau de Bord, por exemplo), o Balanced 
Scorecard fornece um bom ponto de partida para as empresas: as quatro dimensões que não podem ser negligenciadas na gestão estratégica. O Balanced Scorecard alerta que as perspectivas relacionadas aos clientes, aos processos internos e ao aprendizado e crescimento, direcionam o desempenho futuro da perspectiva financeira. Com isso, mostram, com pouca margem de dúvida, sobre o que o gestor deve refletir: quais as ações a serem tomadas naquelas dimensões e se há mais alguma dimensão a ser tratada.

Essa inovação pode ser conferida mediante referências feitas por vários autores. Eccles (1991) já atestava que a dificuldade era combinar as várias dimensões da gestão além da financeira de forma balanceada, incorporando-as ao processo de determinação da estratégia, na concessão de promoções, bônus e recompensas. Chow \& Haddad \& Williamson (1997) destacaram que a inovação do Balanced Scorecard estava na forma elucidativa e integrativa com que seus elementos são desenhados, indicando tanto a perspectiva corrente quanto a perspectiva futura da companhia. Epstein \& Manzoni (1997) (1998) e Malo (2000) ressaltaram que a inovação de definir quatro perspectivas protege contra dois perigos: de a perspectiva financeira, por ter mais informações, de forma mais fácil, acabar por dominar o conjunto (como ocorreu com as empresas francesas) e; de esquecer alguma daquelas dimensões, na definição e desdobramento da estratégia. Garantir que todas as medidas críticas serão avaliadas também é vista, por Willyerd (1997), como vantagem de se utilizar as quatro perspectivas.

O segundo ponto que merece ser chamado a atenção como uma novidade do Balanced Scorecard é que, a forma simples e clara com que Kaplan \& Norton conseguem tratar das interligações existentes entre os processos gerenciais de planejamento e orçamento, se consubstancia na elaboração de um relatório corporativo onde deve constar apenas os objetivos e medidas de cada dimensão que indicam a trajetória do cumprimento da estratégia. 
Esse relatório único força os gestores a refletirem sobre as relações de causa e efeito entre objetivos financeiros e os objetivos das outras dimensões, pois todas elas estarão ali representadas, necessariamente. Na ausência de tal exigência, pode-se apenas apresentar os objetivos financeiros como estratégicos corporativos, caindo no risco já apontado por Skinner (1969) de que a ligação entre a estratégia e a operação fique delegada a postos hierárquicos mais baixos. Ou seja, a confecção de um relatório corporativo onde se apresenta, necessariamente, os objetivos e medidas das quatro dimensões (onde se quer chegar financeiramente e o que é preciso fazer para isso no que se refere aos clientes e a capacitação interna) eleva a gestão da vinculação dos objetivos táticos e operacionais com os estratégicos ao nível corporativo.

A inovação quanto a esse aspecto, assim como sua vantagem podem ser atestadas por vários autores. Chow \& Haddad \& Williamson (1997) destacaram que o poder do Balanced Scorecard está em prover a habilidade em desenhar um scorecard único que atenda especificamente as necessidades da empresa, unidade ou funcionários. Epstein \& Manzoni (1997) afirmaram que a vantagem mais óbvia do Balanced Scorecard é sumariar quatro diferentes perspectivas em um único e sucinto relatório. Em geral as empresas apresentam informações sobre essas perspectivas mas, em diferentes relatórios que, reúnem um número muito grande de informações, não permitindo uma boa análise. Ademais, essa forma de apresentação explicita melhor as escolhas feitas entre as medidas. Mendonza \& Zrihen (1999) apontaram que as quatro perspectivas em apenas um relatório faz do Balanced Scorecard um instrumento adequado para a alta administração da empresa, permitindo uma visão global do desempenho dessa, diferentemente do Tableau de Bord, mais adequado como suporte à tomada de decisão do gestor operacional. 
O equívoco de Allen (1999) está em não levar em conta a maneira como esses "velhos e bons" pontos teóricos foram abordados. O equívoco de Malcolm (1999) está em não levar em conta que esses "velhos e bons" pontos teóricos tiveram sua divulgação facilitada porque foram pensados, refletidos, numa maneira ainda não presente na literatura. Esse repensar permitiu, de fato, que os conhecimentos expressos num "painel de instrumentos" se transformassem, passassem a ser utilizados, como se estivesse em um "simulador de vôo".

Vale a pena registrar que Kaplan \& Norton vêm fazendo alterações na forma de apresentar o Balanced Scorecard na literatura com o intuito de torná-lo mais claro. Uma das menos sutis foi a mudança da disposição de temas dentro das quatro perspectivas (inovação deixa de estar em Inovação e Aprendizado e passa para Processos Internos) por conseguir melhor expressar a idéia das perspectivas ${ }^{92}$. A outra mudança significativa foi a leitura dos processos gerenciais que permeiam a definição das perspectivas e dos indicadores, como princípios, adicionando aos pontos já levantados nos quatro processos, um quinto princípio. $\mathrm{O}$ que eram comentários sobre a dedicação da empresa nas fases pelas quais o Balanced Scorecard se torna um sistema de gestão (Kaplan 1994-a), e sobre a necessidade da alta administração estar envolvida (Kaplan \& Norton, 1992, 1996-a, 1997), passam a constituir o quinto princípio. O destaque ao envolvimento dos executivos líderes em todas as fases de implantação do Balanced Scorecard, vem da constatação de que a importância daqueles comentários soltos não estava sendo bem compreendida (Kaplan \& Norton, 2001). Com isso Kaplan \& Norton continuam promovendo um avanço na compreensão do tema gestão estratégica ${ }^{93}$.

\footnotetext{
92 Essa mudança já foi discutida no primeiro capítulo.

93 Entendido como a gestão do cumprimento da estratégia.
} 
Em suma, a novidade teórica, a vitalidade intelectual, do Balanced Scorecard está em ter repensado processos antigos, de forma a que pontos simples mas vitais, que não estavam articulados claramente na literatura, fossem cristalizados em dois instrumentos de análise: 1) as quatro perspectivas (financeira, clientes, processos internos e aprendizado e crescimento); e, 2) o relatório único. Kaplan \& Norton conseguiram traduzir conceitos expressos na linguagem acadêmica em uma linguagem mais próxima do executivo, reduzindo o esforço de compreensão que o gestor precisa despender para implementar uma gestão estratégica. A articulação de conhecimentos antigos, numa maneira até então não enfatizada, ajuda o gestor a compreender melhor o seu papel.

Malcolm (1999) e Allen (1999) alegaram que o sucesso estava na forma como o Balanced Scorecard tinha sido divulgado. Skinner (1969) já dizia que, geralmente, o tema produção é percebido de modo errado pela alta administração, gerido de forma errada no nível operacional e, ensinado de maneira errada nas faculdades. Seja por problemas de metodologia de ensino nas faculdades, seja por problema de divulgação, os autores supra citados compartilham da visão de que há grande distância entre os "velhos e bons" conhecimentos e a prática de muitas empresas. O Balanced Scorecard ajuda a reduzir a distância entre os "velhos e bons" conhecimentos e a prática de muitas empresas.

\section{4 - CRITÉRIO III: ATENDER ÀS EXIGÊNCIAS EMERGENTES}

A presente seção avalia o Balanced Scorecard à luz do terceiro critério antes estabelecido: se ele pode ser utilizado para se entender exigências modernas, aumentando a compreensão do tema gestão. A conclusão desta seção é que, com base neste critério, o Balanced Scorecard pode ser considerado uma contribuição original à literatura de contabilidade gerencial. 


\subsection{1 - ÚTIL NO NOVO AMBIENTE COMPETITIVO}

Na primeira seção do primeiro capítulo já foi referido que a motivação para o trabalho de Kaplan (1983) foi a avaliação de que a perda, para o Japão, da liderança dos Estados Unidos da América do Norte, em assuntos de gestão e tecnologia industrial, colocava um novo desafio para a pesquisa na área da contabilidade gerencial, de forma a permitir que as empresas norte-americanas retomassem a liderança perdida.

Não é demais repetir: o ponto básico de Kaplan (1983) é que a existência de um novo ambiente competitivo colocara a necessidade de se desenvolver um novo sistema contábil gerencial, para ajudar as empresas norte-americanas a recuperarem a liderança perdida. Não se trata de copiar as bem sucedidas experiências japonesas mas, de criar coisas novas, de acordo com a cultura norte-americana e consentâneas com os novos tempos.

O sistema contábil tradicional de custos baseados em premissas de produções de longo prazo de produtos padrões, sem mudanças de características e especificações, nesse novo ambiente competitivo, perdera a relevância, a utilidade. Os textos contábeis tradicionais não tratavam de técnicas, procedimentos ou propriedades da mensuração de produtividade que, nessa nova fase competitiva, tornara-se uma peça fundamental para a sobrevivência das empresas. Na nova fase competitiva, o investimento em um novo equipamento se justificava apenas pelas economias de mão de obra ou de energia mas, também, e muitas vezes principalmente, por permitir uma programação de produção mais flexível ou mais confiável, reduzindo os níveis de inventário e, consequentemente, os custos totais.

A mudança no clima competitivo, as novas exigências para a contabilidade gerencial, já haviam sido apontadas por Skinner $(1969){ }^{94}$. Está dito nessa obra que os tempos modernos

94 conforme já referido no item "c" (Necessidade de se adicionar medidas não financeiras) de 3.2.1 (Novas mensagens). 
exigiam que medidas financeiras e não-financeiras fossem levadas em conta no processo de gestão. A predominância de elevada competição mercadológica, que levava a existência de uma maior variedade de produtos, de mudanças aceleradas nas características dos produtos e de períodos de produção mais curtos, exigia o recurso a outros indicadores que não os tradicionais, exclusivamente financeiros.

O próprio Allen (1997), que discorda que o Balanced Scorecard tenha alguma originalidade, reconhece estar havendo uma alteração importante no modo como as empresas vêm sendo geridas. Estava-se passando da gestão tática para a gestão estratégica porque, nos novos tempos, o valor do negócio é uma função dos ativos intangíveis (capacidade para inovar, reputação, flexibilidade etc.). O referido autor também reconhece que, em simultâneo, estava ocorrendo uma mudança de ênfase na contabilidade gerencial.

Com o que acabou de ser exposto tem-se argumentos que, combinados com os expostos na seção anterior, sustentam a afirmativa de que o Balanced Scorecard obedece ao terceiro critério para definir se uma teoria é plágio ou contém um contribuição original. $\mathrm{O}$ trabalho de Kaplan \& Norton recorre a temas antigos para responder às necessidades gerenciais emergentes com o novo ambiente competitivo da economia norte-americana, aumentando a compreensão do tema contabilidade gerencial, particularmente na vinculação entre a estratégia e a operação.

\section{5 - CONCLUSÃO}

O Balanced Scorecard é uma contribuição original à literatura de contabilidade gerencial porque:

1) repensa temas antigos, mostrando a vinculação entre pontos vitais que não estavam claramente articulados; 
2) mostra como esses conhecimentos estabelecidos podem ser articulados para serem aplicados aos tempos modernos, para atender às novas exigências;

3) aumentando, assim, a compreensão do tema "vinculação entre estratégia e operação" e aperfeiçoando a literatura de contabilidade gerencial.

Essa contribuição original foi cristalizada num relatório único, contendo medidas de desempenho financeiro e não-financeiro nas quatro perspectivas de gestão (financeira, clientes, processos internos e aprendizado e crescimento). 


\section{4 - DESDOBRAMENTOS}

No capítulo anterior foi mostrado que o Balanced Scorecard é uma contribuição original à literatura de contabilidade gerencial. O presente capítulo é um desdobramento das leituras que fundamentaram a tese ali exposta. Aqui se levanta a hipótese de que as características dessa originalidade podem explicar sua ampla disseminação, seu sucesso na academia e nas empresas mas, essas mesmas características, no entanto, podem ser um dos fatores que contribuíram para criação de um modismo.

\section{1 - AMPLA DISSEMINAÇÃO}

Os motivos para o sucesso não parecem estar exclusivamente nos méritos intrínsecos ao Balanced Scorecard. A existência de um ambiente propício para o surgimento de novas idéias, a decodificação de temas complexos e a integração entre empresas de software e de consultoria são fatores que se somam aos méritos intrínsecos do Balanced Scorecard e podem explicar sua ampla disseminação.

\subsection{1 - AMBIENTE PROPÍCIO}

Algumas circunstâncias devem ser consideradas nessa análise. Uma dessas circunstâncias é que ele chegou ao mercado atendendo a uma antiga demanda por mecanismos que integrassem a estratégia com a operação e incorporassem medidas nãofinanceiras à avaliação de desempenho.

Embora muitas técnicas e conceitos, isoladamente, tenham sido usados pelas empresas na tentativa de mudar o sistema tradicional de avaliação de desempenho e de condução da gestão, alguns autores já chamavam a atenção para a necessidade de alinhar essas mudanças ao propósito maior da corporação. Entre esses autores alinham-se Skinner (1969), Banks \& 
Wheelwright (1979), Hayes \& Garvin (1982), Ohmae (1982), Yavitz \& Newman (1982), Porter (1985), Keegan \& Eiler \& Jones (1989) e, Beischel \& Smith (1991).

A absorção de um novo conceito, pelas empresas, não ocorre imediatamente após a divulgação desse na literatura. A própria maturação do Balanced Scorecard não foi instantânea. É razoável, então, recorrer-se a algumas referências após 1992 para caracterizar a existência de um ambiente propício para o surgimento do Balanced Scorecard.

Uma pesquisa realizada em 1991, pela Ernest Young em conjunto com a American Quality Foundation ${ }^{95}$ citada por Vitale \& Mavrinac (1995), revelou que as empresas norte americanas não fazem, regularmente, uso de medidas de qualidade, de satisfação do consumidor e de desempenho do concorrente.

Tanto McKinnon \& Burns Jr. (1992) quanto Eccles \& Pyburn (1992) salientaram que, para melhorar o desempenho das empresas, os indicadores tradicionais pouco dizem sobre o que deve ser feito de forma diferente da atual. Estaria aí a razão pela qual a contabilidade tem deixado de ser usada como suporte a tomada de decisão.

Hammer \& Champy (1997) ${ }^{96}$, enfatizaram que não é suficiente inovar com a inclusão de medidas não financeiras. É preciso desenvolver, implementar e avaliar medidas que possam conferir se a empresa está tendo ou não sucesso nas suas inovações. Esse ponto é corroborado pela pesquisa, realizada por Stalk \& Weber (1993), que mostrou que muitas empresas japonesas conseguiram promover uma enorme melhora nos sistemas de produção com programas de qualidade, mas não conseguiram transformar essa melhora em lucro. As mudanças, enfatizam esses autores, têm que estar alinhadas à estratégia.

95 ERNST \& YOUNG AND THE AMERICAN QUALITY FOUNDATION (1991). "International Quality Study: the definitive study of the best international quality management practices", 1991.

96 HAMMER, Michael \& CHAMPY, James (1997). Reengineering the Corporation. New York: Harper Business, 1993. Citados em Chow \& Haddad \& Williamson (1997). 
Useem (1998) ${ }^{97}$, citado por Peal (1999), ressaltou a importância dos líderes terem uma visão clara sobre as organizações e sobre o que procuram alcançar.

Essas referências são indicadoras de que os programas isolados de mudanças promovidos pelas empresas não conseguiram preencher a lacuna entre a gestão tradicional e as necessidades imperativas dos novos tempos.

\subsection{2 - DECODIFICAÇÃO DE TEMAS COMPLEXOS}

O Balanced Scorecard, para alguns, trata de questões óbvias na literatura de gestão e administração. Allen (1999), por exemplo, conforme já referido no capítulo anterior, enfatizou a obviedade da necessidade de se fazer o alinhamento das ações à estratégia mediante a ligação entre o orçamento e os planejamentos.

Não é demais, no entanto, relembrar a observação de Kaplan \& Norton (1992), repetida em Kaplan \& Norton (1996-a). Os processos de planejamento e de orçamentação tradicionais, freqüentemente, são conduzidos erroneamente nas empresas. Muitas delas têm procedimentos e até unidades organizacionais separadas para planejamento estratégico e para alocação de recursos e orçamentação.

Para formular seus planos estratégicos, os executivos seniores passam alguns dias no ano, fora da organização, em discussões facilitadas por gerentes seniores de planejamento e desenvolvimento ou por consultores externos. O resultado desse exercício é um plano estratégico contemplando onde a empresa tem expectativa de estar (ou tem esperança ou reza para estar) em três, cinco e dez anos. Tipicamente, tais planos ficam guardados pelos próximos doze meses.

97 USEEM, Michael (1998). The Leadership Moment. [s.1]. Times Books, 1998. 
Enquanto isso, os processos de alocação de recursos e de orçamentação são preparados pela equipe de finanças, estabelecendo objetivos financeiros para receitas, despesas, lucros e investimentos para o próximo ano. Esse orçamento é quase que inteiramente elaborado com números financeiros e geralmente tem pouca relação com os objetivos dos planos estratégicos.

Van de Vliet (1997) registrou que uma pesquisa realizada pela Renaissance Solutions and Business Intelligence ${ }^{98}$ detectou que apenas $60 \%$ dos executivos entendem com clareza a estratégia e a visão da organização onde trabalham. Grant \& Neupert (1999) apresentaram estudos de casos mostrando que mesmo empresas mundialmente conhecidas enfrentam dificuldades de definição e de implementação da estratégia ${ }^{99}$.

Eccles \& Pyburn (1992) apontaram que as barreiras mais frequentes a um sistema de mensuração eficiente são:

1) objetivos confusos;

2) confiança não justificada nos sistemas de feedback informais;

3) resistências geradas por imposição de sistemas de mensurações, sem envolvimento da equipe;

4) armadilha da atividade: quando a empresa foca na mensuração da atividade e não nos resultados.

Booth (1996-a) também contribuiu para que se lembre que nem sempre se observa, na prática, procedimentos que parecem óbvios. É óbvio que os gestores não deviam tomar decisões sem qualquer informação para fundamentá-las, apenas com base no: "eu acredito";

98 Empresa cujo executivo principal é David Norton.

99 As empresas relatadas em Grant \& Neupert (1999) são: Coral Divers Resort, Laura Ashley Holdings PLC, Daimler Chrysler, Eastman Kodak, Royal Dutch/Shell Group, Harley-Davidson Inc., Steinway \& Sons, Amazon.com, Starbucks Corporation, Honeywell Inc., DuPont Teflon, Virgin Group of Companies, Imasco Limited, Seagran e MCA Inc., General Eletric e AES Corporation. 
"na minha opinião" mas, na prática, esse erro é encontrado com freqüência. Mais corriqueiro e problemático são os gestores que tomam decisões com base em informações erradas.

Booth (1996-a) relacionou os problemas mais comuns encontrados na prática:

1) predominância de medidas de curto prazo sobre as de longo - levando a sacrificar desenvolvimento de longo prazo por ganhos imediatos;

2) predominância dos aspectos financeiros sobre os outros da realidade - linguagem dos ganhos, retornos etc.;

3) predominância de medidas de eficiência sobre as de eficácia - a produtividade ganha precedência sobre o valor do produto;

4) predominância de medidas de economia sobre as de eficiência - muitas vezes sequer a eficiência no consumo dos recursos é apurada. As medidas apuram apenas o quanto se gastou de recursos;

5) predominância de medidas funcionais sobre as relacionadas com os consumidores - foco no desempenho do departamento, sem considerar a satisfação dos consumidores.

É possível e provável que Skinner (1969) estivesse com a razão quando se referiu à forma inadequada como os assuntos relacionados a gestão costumavam ser lecionados nas faculdades. É possível, portanto, que esse distanciamento seja devido ao padrão de ensino que não explicitava as idéias essenciais subjacentes aos processos de planejamento e orçamentação.

O Balanced Scorecard, é fruto do esforço de repensar e integrar conhecimentos solidamente estabelecidos na literatura, decodificando temas complexos, explicitando as 
interligações entre eles e enfatizando determinadas perspectivas de análise, com o objetivo de permitir que as empresas enfrentem o aumento no grau de competitividade.

A comparação entre a complexidade dos temas expostos isoladamente na literatura e a simplicidade ${ }^{100}$ do Balanced Scorecard é uma boa indicação do esforço intelectual combinando reflexão teórica e observação das práticas das empresas. Idéias simples, frequentemente, se originam de raciocínios sofisticados e não devem ser confundidas com idéias primárias.

Além do mais, não se pode confundir o grau de dificuldade para entendermos uma idéia com o grau de dificuldade para implementá-la. Ao entendermos o mecanismo de funcionamento de algo, estamos entendendo o critério pelo qual nos guiaremos na sua implementação. Nada nos diz, entretanto, sobre as dificuldades para operacionalizá-lo.

A existência da força da gravidade, por exemplo, pode nos parecer óbvia pois podemos atestá-la o tempo todo. Cumprir as regras para vencê-la, na aviação, no entanto, exige um esforço intelectual e operacional com elevada complexidade.

A própria finalidade da ciência e teoria é expressar em modelos, em regras, em leis, o que acontece na realidade. Alguns desenvolvimentos teóricos são mais difíceis de serem compreendidos pois não estamos observando o fenômeno a todo instante, que muitas vezes é observado apenas por um seleto grupo de estudiosos.

Outros fenômenos, no entanto, são facilmente verificáveis, mesmo pelos não especialistas. Nas ciências humanas, há muitos fenômenos desse tipo. As regras gerais desses fenômenos tentam captar o comportamento das expectativas e racionalidades dos agentes envolvidos. Para isso, muitas suposições são feitas e hipóteses testadas.

$\overline{100}$ A simplicidade do Balanced Scorecard foi ressaltada em Kaplan (1994-b). 
Os estudos sobre gestão e administração procuram racionalizar ao máximo as atividades necessárias para conduzir um negócio, de forma a depender menos da capacidade de organização e de iniciativas individuais. Assim, as competências necessárias se diferenciam de acordo com os papéis nos processos gerenciais.

O Balanced Scorecard dá, inicialmente, um critério de racionalidade para definir o que é essencial ser medido e gerido para cumprir a estratégia. Depois, a discussão evolui para o delineamento dos processos gerenciais que deveriam permear essa definição, já que os processos de planejamentos e de orçamento, implementados pelas empresas, perderam muito de seu vigor e eficácia por terem se distanciado de suas concepções originais.

\subsection{3 - INTEGRAÇÃO EMPRESAS DE SOFTWARE - CONSULTORIAS}

Além do ambiente propício para novas abordagens, um segundo ponto ajuda a explicar a disseminação, o sucesso, do Balanced Scorecard. O desenvolvimento da informática, facilitando a ligação das informações, dentro e fora da empresa, também contribuiu para a propagação da utilização do trabalho de Kaplan \& Norton pelas organizações ${ }^{101}$.

Várias empresas de software desenvolveram aplicativos com o objetivo de implementar o Balanced Scorecard, ligando os objetivos estratégicos aos operacionais, sempre sob a supervisão de renomadas empresas de consultorias.

Esses aplicativos, como já referido no segundo capítulo, são classificados, na terminologia da área de tecnologia da informação, como aplicativos de Gestão de Desempenho Empresarial (EPM - Enterprise Performance Management).

Os aplicativos de Gestão de Desempenho Empresarial, em geral, incluem um módulo para gerir a estratégia e outros para medir e analisar a operação, sempre de maneira ligada à

\footnotetext{
101 Holt (1998); Surveyer (1998).
} 
estratégia. Ou seja, os módulos visam fazer a ligação entre os sistemas de informação das empresas, de forma que se possa estabelecer as relações de causa e efeito em um só aplicativo.

A Gentia Software - desenvolveu, sob consultoria da Renaissance Worldwide (cujo sócio principal é David Norton) e da Arthur Andersen, um conjunto de aplicativos de Gestão de Desempenho Empresarial (em tecnologia OLA ${ }^{102}$ ), aplicando os conceitos do Balanced Scorecard: Gentia Balanced Scorecard ${ }^{103}$, para gerir a estratégia, Gentia Performance Impact, para gerir a operação e Gentia Profit Impact, para analisar a operação, incorporando o método de custeio ABC (Activity-Based-Costing).

A PeopleSoft também lançou um aplicativo de Gestão de Desempenho Empresarial que tem o módulo PeopleSoft Balanced Scorecard ${ }^{104}$ como o sistema nervoso central do aplicativo, que inclui outros módulos de análises operacionais (inclusive o Activity-Based Management). A Peoplesoft teve como parceiros a KPMG LLP, a Andersen Consulting, a Balanced Scorecard Collaborative, Robert Kaplan e Robin Cooper.

A CorVu também recebeu o certificado da Balanced Scorecard Collaborative que atesta a aplicação da metodologia de Robert Kaplan e de David Norton. O módulo do aplicativo de Gestão de Desempenho Empresarial (também desenvolvido em tecnologia OLAP) que inclui as aplicações de Balanced Scorecard é o CorManage ${ }^{105}$.

102 OLAP, on line analytical processing, é uma tecnologia multidimensional de banco de dados que ao invés de guardar as informações de forma linear, como a tecnologia convencional faz (banco de dados relacional), guarda-as em "cubos", como se cada informação tivesse várias dimensões: ao verificar um indicador, por exemplo, poderia-se vê-lo por divisão, por região, por grupo de cliente ou por qualquer outra dimensão que lhe fosse pertinente, aumentando ou diminuindo o detalhe. The (1995) e Asbrand (1997).

103 Para mais informações sobre o aplicativo, ver www.gentia.com.

104 Para mais informações sobre o aplicativo, ver www.peoplesoft.com.

105 Para mais informações sobre o aplicativo, ver www.corvu.com. 
Também é certificado pela Balanced Scorecard Collaborative o módulo $\underline{\text { SAP SEM }}$ Balanced Scorecard do aplicativo de Gestão Empresarial denominado SEM - Strategic Enterprise Management da SAP ${ }^{106}$. Todos os módulos são desenvolvidos sob esse conceito com o objetivo de traduzir a estratégia em ação.

A Show Business Software, em parceria com a Lotus Business, sob a consultoria da Arthur Andersen Business Consulting, desenvolveu um aplicativo de Balanced Scorecard para Lotus Notes e Intranet, denominado Action Driven Balanced Scorecard-(ADBS) ${ }^{107}$.

Esses grandes fornecedores de "pacotes" ao reconhecer o poder do novo nicho de mercado, conduz a uma divulgação ainda mais ampla.

O Balanced Scorecard foi desenvolvido também como instrumento de apoio à consultoria. Como esse desenvolvimento teve sucesso, as empresas de consultorias, em parceria com os desenvolvedores de software ou não, acabaram tornando-se divulgadoras do trabalho de Kaplan \& Norton.

\section{2 - MODISMO}

McCunn (1998) afirmou que, para a indagação sobre os motivos que levaram a adoção do Balanced Scorecard, a resposta individualmente mais significativa, provavelmente, seria: "meu amigo do clube de golf implantou". Outra resposta significativa seria: "fiquei impressionado com a palestra de um consultor". Uma terceira resposta relevante seria: "um dos diretores permanentemente procura inteirar-se das últimas ferramentas de gestão”.

O sucesso do Balanced Scorecard, na academia e nas empresas, levou à constituição do que Kurtzman (1997) chamou de dois tipos de credo: a) o credo do "The Balance People",

\footnotetext{
106 Para mais informações sobre o aplicativo, ver www.sap.com/sem.

107 Para mais informação sobre o aplicativo, ver www.showbusiness.com ou www.lotus.com.
} 
liderado pela Analog Devices; e, b) o credo do "The Numbers People", liderado pela Shell Oil.

Axson (1999) comentando o resultado de pesquisas ${ }^{108}$ sobre planejamento em empresas, feitas pelo The Hackett Group (que faz estudos constantes de benchmarking sobre planejamento) ressaltou que, embora metade das organizações usem algum tipo de Balanced $\underline{\text { Scorecard, }}$ combinando medidas financeiras e não financeiras, o seu impacto não é tão pronunciado quanto se possa imaginar.

Outro resultado surpreendente dessa pesquisa foi a constatação de que, nas empresas que usam o Balanced Scorecard, quase três quartos das medidas ainda são financeiras, ou seja, não existe um verdadeiro balanceamento entre as medidas financeiras e as não financeiras. Igualmente surpreendente foi a constatação de que o percentual (cerca de 75\%) de medidas financeiras entre as empresas que se dizem utilizar os conceitos do Balanced Scorecard não está muito longe do percentual (cerca de 80\%) de medidas financeiras entre as empresa que dizem não recorrer ao conceito do Balanced Scorecard ${ }^{109}$. Essa mesma pesquisa constatou que as empresas que dizem utilizar algum "tipo" de Balanced Scorecard, surpreendentemente, ainda mantêm o foco em medidas internas e históricas.

Em suma, o Balanced Scorecard parece estar tornando-se um modismo. Mesmo experiências que não guardam relação com os conceitos do Balanced Scorecard passaram a ser assim denominadas. De um lado, surgiram várias críticas indevidas. De outro lado,

108 Essa pesquisa também foi objeto de Editorial da Management Accounting London: Planning processes 'overlong and inefficient'? Management Accounting, London, v. 76, p.10, Nov 1998.

109 Axson (1999) afirma que é um tanto "tolo" supor que, no Balanced Scorecard, todas as dimensões e medidas devam ser balanceadas. A tentativa de balanceá-los, para esse autor, "cheira a um tipo de comunismo gerencial". Os componentes não devem ser balanceados mas combinados de forma a refletir uma hierarquia de importância (biased). A tese de Axson (1999) não procede porque, no Balanced Scorecard, não existem conflitos entre as dimensões e as medidas, todas devem estar estabelecidas de forma a expressar o objetivo comum a ser alcançado. A existência de conflitos expressa uma definição dúbia da estratégia. 
subestimaram-se os problemas de implantação e aspectos fundamentais para a gestão que não são tratados pelo Balanced Scorecard.

\subsection{1 - SUBESTIMAÇÃO DAS DIFICULDADES DE IMPLANTAÇÃO}

Bourne \& Neely (1998) lembraram que qualquer implantação de novos métodos gerenciais deve levar em consideração que: 1) o esforço do gestor é um recurso limitado; 2) há vários projetos e iniciativas que competem pelo tempo do gestor; 3) o gestor faz escolhas e prioriza essas iniciativas com base no esforço exigido percebido e na recompensa esperada percebida (dado a melhora de desempenho); e, 4) as percepções do gestor mudam ao longo do tempo, com a experiência.

Segue-se, então, que: 1) se o projeto exigir prioridade e esforço acima da disponibilidade total, será encerrado; 2) se a expectativa de benefício de um projeto se reduzir, a sua prioridade também se reduzirá; 3) se a expectativa em relação ao esforço exigido em um projeto aumentar, sua prioridade cairá; e, 4) no longo prazo, os benefícios esperados e os alcançados se convergirão.

Hatch (2000) ressaltou que, ao se iniciar um processo de mudança, é preciso levar em consideração o perfil da organização e de seu dirigente. Sua tipologia de executivos e a sua teoria de evolução da empresa contribuem para a compreensão de que nem sempre se deve implantar um Balanced Scorecard.

O referido autor divide os executivos em dois tipos: o vaqueiro (cowboy) e o colonizador (settler). O executivo do tipo vaqueiro (cowboy) é um pioneiro. As características de seu perfil são: a coragem, a determinação, auto controle, auto suficiência, aptidão técnica, ambição de condução e a habilidade para comunicar-se, mediante suas ações e suas palavras. O que os fazem vaqueiros é a disposição para viver na margem desconfortável da civilização, 
tanto literalmente quanto metaforicamente. Os empreendedores com aptidão técnica não gostam de "porteiras".

Muitas organizações precisaram desse tipo de executivo para alcançar a excelência, mas depositar confiança demasiada no estilo do vaqueiro é letal para a consistência, eficiência e colaboração na organização.

O papel do executivo tipo colonizador (settler) é o de impor limites aos piores excessos dos executivos de tipo vaqueiro. Quando a organização passa da fase de desbravamento para uma de maturação e consolidação (colonização), o desafio é manter as qualidades da característica do tipo vaqueiro e promover as mudanças necessárias de gestão. Em geral, os componentes que fizeram com que a empresa se tornasse um grande império, passam a ser desfuncionais. A competitividade interna gerada no ambiente organizacional com tais características leva a comportamentos individualistas, a não compartilhar conhecimentos, ao contrário, a competir com os colegas, num mesmo projeto, pela recompensa. Nesse estágio, a sinergia desaparece e a organização começa a perder competitividade. Quando o executivo tipo vaqueiro não promove essas mudanças ele "dá um tiro no pé”.

O Balanced Scorecard é uma das formas de se promover essas mudanças. Não adianta, no entanto, implantá-lo antes que a organização esteja madura para passar da fase "vaqueiro" para a fase "colonizador". A empresa precisa estar culturalmente preparada, ter como objetivo aquilo em que pode ser ajudada pelo Balanced Scorecard.

Birchard (1996) relatou a experiência da Univar que, sem estar culturalmente preparada, fracassou ao tentar implantar o Balanced Scorecard. A empresa vinha incorrendo em prejuízos e imaginou que a implantação do Balanced Scorecard era suficiente para 
revertê-los. A implantação, por não expressar mudanças culturais, não levou à melhoria esperada nos desempenhos financeiros de curto prazo. O Chief Executive Officer (CEO), então, foi despedido e assumiu um outro gestor, que encerrou a experiência do Balanced Scorecard e reconstituiu o modo antigo.

O próprio texto de Birchard (1996) reproduz a opinião de Norton, de que o Balanced Scorecard não é um conceito apropriado para empresas cujo foco está no corte de custos e sobrevivência de curto prazo; o conceito do Balanced Scorecard é adequado para gerir a estratégia e o crescimento de longo prazo.

Lewy \& Lex du Mee ${ }^{110}$, citados em McCunn (1998), a partir de um estudo de caso em sete empresas européias, estabeleceram os dez mandamentos da implantação do Balanced Scorecard. Pode-se daí extrair uma lista ${ }^{111}$ de erros de implantação cometidos pelas empresas, que comprometem o sucesso do Balanced Scorecard.

O primeiro erro é implantá-lo sem uma definição clara e prévia da estratégia. Definila, ou alterá-la, ao longo da implantação conduz ao fracasso. O scorecard não é útil para definir e sim para implementar os objetivos estratégicos. O segundo erro é implantá-lo sem o absoluto comprometimento da alta administração e dos gerentes de linha. Sem tal comprometimento, o resultado será um arremedo de ação gerencial.

O terceiro erro é implantá-lo para obter um controle extra de cima para baixo. Tal tentativa só gerará uma forte reação contrária das pessoas. Não basta que a alta administração esteja motivada, é preciso que a empresa como um todo entenda as vantagens e a necessidade de implementar o Balanced Scorecard.

\footnotetext{
110 LEWY, Claude \& DU MEE, Lex. The ten commandments of balanced scorecard implementation. Managing Control and Accounting, Apr. 1998.

111 Essa listagem não obedece rigorosamente ao que está no texto citado mas, expressa a compreensão que a autora desta Dissertação tem do referido texto.
} 
O quarto erro é implantar um projeto padronizado pois, cada organização tem que ter a sua estratégia própria. O mesmo Balanced Scorecard não deverá servir para duas empresas no mesmo segmento, do mesmo tamanho, porque as pessoas que integram essas empresas são diferentes e terão diferentes reações, qualificações, percepções da realidade, combinações de recursos diferentes etc.

O quinto erro é implantá-lo sem ter feito, previamente, um projeto piloto, que forneça lições valiosas e evite o risco de um grande desastre. O sexto erro é implantá-lo sem efetuar uma entrevista preliminar com cada unidade de negócio. Tais entrevistas minimizam o risco de seguir em frente em circunstâncias desfavoráveis e permitem que se adeqüe o projeto para atender às necessidades da organização.

O próximo conjunto de erros tem sua origem na subestimação do Balanced Scorecard. Algumas empresas podem se deixar enganar pela simplicidade da idéia. É preciso, no entanto, ter presente que o poder de transformação é ampliado pela simplicidade. O Balanced Scorecard é uma idéia simples mas poderosa, que pode produzir grandes mudanças nas organizações.

O sétimo erro consiste em subestimar as necessidades de treinamento e comunicação exigidas. O oitavo erro é subestimar os custos e a carga extra de trabalho administrativo dos períodos de divulgação dos scorecards periódicos. A coleta de informações para o scorecard é mais tempo-intensiva do que se imagina. Descobrir isso tardiamente pode levar à desistência ou ao uso deficiente do Balanced Scorecard. O nono erro é buscar a complexidade ou a perfeição. Tal busca leva à postura de deixar de agir para ficar analisando ("paralysis by analysis”), atrasando e comprometendo a implantação. 
Essa lista deve ser ampliada com o erro apontado em Bontis \& Dragonetti \& Jacobsen \& Roos (1999). O décimo erro, portanto, é não levar em consideração que muitos fatores críticos de sucesso (provavelmente, a maioria deles) não podem ser classificados em uma única perspectiva. Cabe ao gestor saber identificar essas interdependências e impedir que a busca da simplicidade transforme-se em primarismo.

Mooraj \& Oyon \& Hostettler (1999) forneceram elementos para se apontar três outros erros que produzem fracassos na implementação do Balanced Scorecard. O décimo primeiro erro é subestimar os conflitos com outros sistemas gerenciais de controle que estão em uso na organização. É preciso, portanto, ter especial atenção para a integração com outros sistemas. O décimo segundo erro está em subestimar as resistências culturais (nacionais, profissionais e organizacionais). É preciso levar em conta as tradições da organização. O décimo terceiro erro está em desconsiderar a existência de eventos relevantes que não são mensuráveis e que podem alterar o ambiente competitivo onde a empresa opera.

O estudo de Lewy \& Du Mee ${ }^{112}$ (citado em McCunn, 1998) registrou que duas empresas, apesar de falharem na intenção original de tornar o Balanced Scorecard o coração dos processos de controles da organização, consideravam ter tido sucesso porque haviam conseguido promover a consciência da importância das medidas não financeiras. McCunn (1998) observou, então, que a implementação de um projeto de Balanced Scorecard é um meio muito caro e tempo-intensivo para promover essa consciência.

Riccio (1989) forneceu a argumentação para que, aqui, se aponte um décimo quinto erro: sem um sistema de banco de informações básico não adianta ter ferramentas como Balanced Scorecard, EIS etc.

$\overline{112 \text { Lewy \& Du Mee, op.cit., } 1998 .}$ 
Se o sistema de informação da empresa não for desenhado adequadamente, respeitando os processos de tomada de decisão quanto ao planejamento, execução e controle, e não for integrado, permitindo a desagregação de uma informação em maiores detalhes em um mesmo sistema, fica difícil vincular objetivos e medidas de estratégia e de operação, gerir a estratégia, tal como proposto por Kaplan \& Norton. A integração das informações pelos vários níveis da empresa deve atender a necessidade de detalhamento de cada nível.

Para gerir a estratégia é fundamental que ela seja desdobrada, de forma clara, em outros objetivos, nos vários níveis organizacionais. O sistema de informação desempenha um papel importante nessa tarefa. Ao se detectar um problema mediante um indicador geral, em um scorecard, o sistema de informação da empresa, ao detalhar ou sumariar as informações ao longo dos diferentes níveis organizacionais, permite ao gestor identificar a origem do problema.

Sem uma integração sistêmica do Balanced Scorecard com o sistema de informação da empresa, a organização pode ser desestimulada a continuar com a sua utilização, em razão do elevado custo operacional de manter o controle dessa vinculação (“drill down" dos indicadores estratégicos até os operacionais) e do custo de produzir os indicadores.

A integração, no entanto, não é a única condicionante para se dar suporte ao Balanced Scorecard. Os sistemas de informação da empresa devem estar estruturados de forma adequada para essa integração.

Para que se possa efetivamente retratar a organização em suas várias dimensões, para efeito de planejamento e de controle, é preciso ter um sistema de informações adequado aos processos de planejamento e de controle da organização. A maneira como os indivíduos se 
comportam em relação à informação - como eles a adquirem, filtram, analisam e comunicam - é tão importante para a organização quanto a própria informação.

Assim, segundo Keen \& Morton (1978), é preciso ter claro para quais decisões se pretende dar suporte mediante o sistema. É preciso ter clareza do que se pretende obter como produto de um sistema de informação, pois as soluções tecnológicas disponíveis são as mais variadas. Se os gestores o souberem, poderão construir um sistema que atenda a maioria de seus objetivos.

Segundo Riccio (1989), os sistema de informação, geralmente, são estruturados desconsiderando a utilidade das informações para a empresa como um todo, como se fosse um sistema restrito à Contabilidade ou à Área Financeira. Eles não costumam ser estruturados para ser a base de todas as informações necessárias na empresa. Resulta, então, que a utilidade e os mecanismos desse sistema não são difundidos pela empresa. Os planos de contas, muitas vezes, não são adequadamente estruturados, produzindo informações resumidas que só interessam a Contabilidade. Informações que seriam naturalmente fornecidas pela Contabilidade passam a ser fornecidas com a proliferação de sistemas paralelos ou extra contábeis. Esses sistemas paralelos exigem mais pessoas, mais software (que muitas vezes são incompatíveis entre si). O resultado final é uma colcha de retalhos que não permite a obtenção da informação em tempo real, deteriora o controle e a segurança dos dados e das informações, aumentando a possibilidade de erros e fraudes.

Em suma, a proliferação de sistemas paralelos tem como conseqüência: a) a produção de informações redundantes (várias unidades produzindo as mesmas informações, nem sempre com a mesma qualidade); b) a ocorrência de gastos desnecessários com recursos; c) a desintegração entre as diversas áreas; d) o descrédito no sistema contábil e nas suas reais possibilidades; e, e) o não atendimento às necessidades de informação da empresa. 
Se o Balanced Scorecard for implantado tendo como suporte sistemas paralelos para gerar tais indicadores, a informação a ser usada estará sujeita aos problemas apontados por Riccio (1989) e, assim, se estará pondo em risco um dos requisitos do Balanced Scorecard: a comunicação da estratégia. Esses problemas são: a perda de integridade e de qualidade dos dados, o aumento dos custos da informação na empresa e a impossibilidade de promover a integração das áreas.

Um erro comum é deixar a tecnologia de informação dar a direção das mudanças. É um equívoco supor que a tecnologia fornece, automaticamente, a resposta organizacional apropriada. Um sistema de informações que promova a eficácia das decisões gerenciais precisa ser desenhado não pelos especialistas profissionais de tecnologia mas pelo gestor, que além de desenhar deve controlar o sistema, pois ele é quem conhece a complexidade do processo de tomada de decisão e está familiarizado com as integrações entre as áreas funcionais da empresa.

Martins (1996) lembrou que a escolha do sistema, assim como o seu detalhamento, devem ser adequados ao que se pretende obter de suporte, vis a vis o custo para isso. Vencidas as etapas de elaboração, cumpriu-se uma etapa necessária, mas não suficiente, para garantir a obtenção do controle. Há que se levar em conta o processo decisório dos gestores. É preciso ter clareza de que o sistema de suporte a decisão não substitui o julgamento gerencial. Na mesma linha, Iudícibus (1999) ressaltou que a falta de uma contabilidade estratégica totalmente desenvolvida de forma sistêmica, pode ser suprida pela qualidade dos profissionais envolvidos, que devem saber pensar corporativamente.

O sistema de informação contábil, conforme mostrado por Riccio (1989), por sua lógica interna, tem potencial para constituir-se na peça fundamental do sistema de informação gerencial da empresa, amarrando e provendo informações monetárias e não monetárias 
destinadas às decisões dos níveis operacional, tático e estratégico. O sistema de informação contábil, portanto, pode ser utilizado como suporte para o Balanced Scorecard. O sistema de informação contábil, no entanto, só será utilizado em todo seu potencial se aquelas dificuldades, relacionadas por Riccio (1989), forem superadas.

Em suma, para o Balanced Scorecard ser implantado com sucesso é preciso cuidar para não incorrer no erros relacionados pelos vários autores supra citados.

\subsection{2 - SUBESTIMAÇÃO DAS DIFICULDADES ADICIONAIS}

O Balanced Scorecard apesar de ser uma importante contribuição para a literatura de contabilidade gerencial, repensando temas já estabelecidos e fazendo sua aplicação para atender a necessidades gerenciais emergentes, aumentando a compreensão sobre a vinculação entre a estratégia e a operação, está longe de ser e nem tem a pretensão de ser uma enciclopédia de gestão.

Otley (1987) chamou a atenção para questões básicas que devem ser respondidas por qualquer sistema de avaliação de desempenho: a) qual a dimensão do desempenho da organização que deve ser estimulada; b) qual o padrão apropriado para medi-la; e, c) como vincular isso com as recompensas aos trabalhadores?

O Balanced Scorecard trata a primeira questão de uma forma peculiar. O que deve ser enfatizado não é a dimensão mas a estratégia e as metas estratégicas em cada uma das dimensões de gestão vitalmente vinculadas à ela. A questão a ser feita não é sobre qual a dimensão a ser enfatizada pois, metas de diferentes dimensões podem ter a mesma prioridade na agenda e, em uma mesma dimensão pode haver metas que serão alcançadas em tempos diferentes dada a relação causal entre as ações. 
Não há uma "receita de bolo" para identificar o que deve ser atacado primeiro. A relação de causa e efeito entre as ações para alcançar as metas delineadas é que determinará a ordem em que devem ocorrer e, portanto, o momento em que devem ser enfatizadas.

O Balanced Scorecard tem uma boa resposta para a primeira questão mas não tem respostas para as duas outras, o que mostra que ele está longe de ser um instrumento completo de gestão.

\section{a) padrão de medida}

Esse ponto levantado por Otley (1987) está melhor tratado por Moon \& Fitzgerald (1996), que chamaram a atenção que a definição de padrões envolve três tipos de considerações: 1) quem define o padrão (ownership); 2) qual o nível adequado para sua fixação (achievability); 3) como fazer com que o padrão fixado tenha o mesmo nível de dificuldade de obtenção em todas as unidades da organização (equity)?

Não existe consenso na literatura sobre quem deve definir o padrão, se a definição deve vir de cima, da alta administração ou se deve ser conseguida num esquema participativo, onde os empregados sejam ouvidos. Quando a definição vem de cima, corre-se o risco de estipular um padrão num nível de dificuldade tão grande para os trabalhadores que o sistema acaba produzindo resultados opostos do esperado. Metas que são praticamente impossíveis de serem alcançadas desestimulam os empregados a lutarem para alcançá-las. Quando a definição conta com a participação ativa dos empregados, corre-se o risco de se gerar um orçamento irrealista (budgetary slack), com superestimação dos custos e subestimação das receitas. Com um orçamento facilmente alcançável, não se consegue estimular os empregados para gerarem o melhor desempenho da organização. 
Uma dificuldade adicional está em que a estratégia da empresa pode levar à fixação de padrões e metas que, necessariamente, serão mais facilmente alcançados por uns setores do que por outros setores da organização. Nesse caso, pode-se desestimular tanto os empregados nos setores onde a dificuldade é maior quanto os empregados nos setores onde a dificuldade é menor e, consequentemente, não se gerar o melhor desempenho dos empregados/organização.

Mesmo que se consiga estabelecer um padrão e, em função dele, se consiga estabelecer metas adequadas à estratégia da organização, que sejam factíveis e igualmente difíceis para todos os setores, o sucesso da organização só será alcançado se se conseguir superar três dificuldades, apontadas por Moon \& Fitzgerald (1996), na vinculação da avaliação de desempenho com o sistema de recompensa aos empregados.

\section{b) vinculação com recompensa}

Kaplan \& Norton (1996-a), Kaplan \& Norton (1997) e Kaplan \& Norton (2001), alertaram que, para o Balanced Scorecard mudar a cultura da organização, é preciso estar acompanhado de um sistema de recompensa baseado em alcance das medidas estratégicas. Para que as metas estabelecidas sejam alcançadas é preciso balancear o conjunto de indicadores que servirão de base para o sistema de recompensa, de forma a que as pessoas se sintam motivadas a cumprir as metas das quatro perspectivas. Adicionalmente, sugere que o Balanced Scorecard pode ser um fator de estímulo à motivação intrínseca dos empregados, porque permite a identificação das suas tarefas/funções com o objetivo da organização.

É óbvio que o Balanced Scorecard não pretende ser um compêndio de gestão e, nesse sentido, tais observações sobre a vinculação com o sistema de recompensa podem ser consideradas suficientes. Kaplan \& Norton (2001) comentaram que não identificaram uma 
forma de se estabelecer essa vinculação que fosse preferível ou dominante. Cada uma das empresas por eles estudadas, a fizeram de uma forma diferente.

O objetivo da presente seção, é levantar alguns pontos além do Balanced Scorecard, nessa vinculação.

Moon \& Fitzgerald (1996) chamaram a atenção que, do ponto de vista dos empregados, o sistema de recompensas precisa: 1) estar suficientemente esclarecido para todos eles (clarity); 2) conter elementos que realmente os motivem (motivated); e, 3) não cobrar resultados que envolvam áreas que não estão sob seus controles (controllability).

Para o Balanced Scorecard, é fundamental que a estratégia e os scorecards sejam comunicados por toda a empresa, a fim de permitir os seus desdobramentos em metas, ações e medidas. Assim, para que o sistema de recompensa consiga incentivar as pessoas a agirem na direção desejada, é preciso que o mecanismo de avaliação de seus desempenhos esteja claro para elas. Não pode haver dúvidas do que será incentivado.

Quanto à motivação, Austin \& Larkey (2000) ressaltaram que, sempre que não se conseguir medir adequadamente uma dimensão crítica do trabalho produtivo, o sistema de recompensa não será perfeito mas, insuficiente, incompleto. A dimensão de uma atividade é crítica quando não se consegue produzir qualquer valor (produto) sem se devotar algum esforço nessa dimensão. O trabalho de Blau (1963) ${ }^{113}$, citado por Austin \& Larkey (2000) mostrou que os trabalhadores desviam seus esforços das tarefas que não são medidas para as tarefas que são medidas pelo sistema de avaliação de desempenho. Como o esforço desenvolvido para o cumprimento de uma tarefa crítica não era medido, ela deixou de ser realizada e, consequentemente, o objetivo da organização ficou mais difícil de ser alcançado.

113 BLAU, P. M. The dynamics of bureaucracy: a study of interpersonal relations in two government agencies. Chicago: The University of Chicago Press, 1963. 
No caso tratado por Blau (1963) ${ }^{114}$, agências governamentais para atendimento aos desempregados, os trabalhadores eram avaliados pelo número de entrevista e não pelo número de empregos permanentes que conseguiam para os desempregados. O resultado desse sistema de avaliação de desempenho foi o aumento significativo da relação entrevista/emprego conseguido.

Kerr (1975) forneceu uma lista de exemplos onde o sistema de recompensa não estimula a obtenção da finalidade precípua da organização ou da atividade. Um dos casos mais interessantes ali referidos é o sistema de recompensa nas universidades. Espera-se que os professores universitários não negligenciem suas atividades didáticas mas, como não se tem um bom indicador dessa atividade, costuma-se recompensá-los pelo que é possível ser medido e que constitui pressuposto do bom desempenho na sala de aula. Espera-se que os professores universitários ministrem boas aulas mas recompensam-nos por pesquisas e publicações. O resultado, consequentemente, não é o melhor desempenho didático dos professores.

Outro ponto salientado por Kerr (1975) é que nas organizações onde se adota o sistema de Gestão por Objetivos (Management By Objectives - $M B O$ ), espera-se que os empregados esforcem-se para constituírem um time integrado, com relacionamentos pessoais, criatividade etc. mas o sistema de recompensas não premia qualquer uma dessas “esperanças". Espera-se, também, que a empresa tenha longa duração e, consequentemente, que os gestores estejam atentos para a evolução dos custos no longo prazo mas, eles são avaliados pelos resultados de curto prazo.

\footnotetext{
114 Em Austin \& Larkey, op.cit., 2000.
} 
Um ponto relevante do trabalho de Blau (1963) ${ }^{115}$, que foi corroborado por Austin (1996) ${ }^{116}$ citados por Austin \& Larkey (2000), é que não se resolve o problema com a melhoria da tecnologia de mensuração, alterando o que se está medindo. Essa tentativa apenas produz comportamentos disfuncionais mais sofisticados. Para ambos os autores, as disfunções nas mensurações são um problema inevitável, persistente e invisível.

Dos trabalhos de Austin \& Larkey (2000), de Austin (1996) ${ }^{117}$, de Kerr (1975) e de Blau (1963) ${ }^{118}$, pode-se deduzir que, existe uma grande distância entre gerir por indicadores e estimular a produção de valor. Com a gestão por indicadores, corre-se o sério risco de não se estimular a produção de valores (produtos) e sim a produção de índices. Não existe sistema perfeito de vinculação entre avaliação de desempenho e recompensa.

O caso polar da dificuldade para a vinculação entre a avaliação de desempenho e o sistema de recompensas aos empregados é o dos trabalhadores cujo instrumento de trabalho é o conhecimento (knowledge worker), um tipo de trabalhador cada vez mais comum nas empresas modernas. Austin \& Larkey (2000) enfatizaram que a natureza do próprio trabalho e as características desses trabalhadores fazem desse tipo de trabalho um desafio para os gestores, que não tem sido adequadamente tratado nos modelos de agência.

Os modelos de agência trabalham com uma organização constituída por um principal, que controla os meios de produção, um agente, que se oferece para trabalhar com esses meios de produção e, uma relação contratual entre o agente e o principal. O principal quer ganhar o máximo pagando o mínimo. O agente quer despender o mínimo de esforço e ganhar o máximo de recompensa. Um elemento de risco pode ser incorporado a esse esquema: o nível

115 Blau, op.cit, 1963.

116 AUSTIN, Robert D. Measuring and managing performance in organizations. New York: Dorset Houes, 1996.

117 Austin, op.cit., 1996.

118 Blau, op.cit., 1963. 
de esforço do agente só é conhecido pelo principal mediante sinais probabilísticos (medidas de desempenho). A questão a ser solucionada é: qual o contrato de compensação ótimo que pode ser derivado das medidas de desempenho?

Os referidos autores lembraram que os gestores não têm o mesmo nível de conhecimento científico dos empregados e não podem, portanto, fazer o que eles fazem nem conhecer exatamente o andamento dos trabalhos, ainda que hajam relatórios freqüentes. É muito difícil observar e avaliar o trabalho e os produtos desse tipo de trabalho pois, os métodos de trabalho, freqüentemente, são precariamente conhecidos pelos gestores e os produtos são intangíveis e não facilmente pré-especificados. Mais ainda, o trabalho é colaborativo, o que faz com que seja difícil saber quanto cada trabalhador está contribuindo para o produto total. O resultado é que os sistemas de recompensa, baseados em medidas individuais de contribuição ao produto (lucro), freqüentemente são inapropriados e, mesmo, algumas vezes, perversos.

As teorias de agência supõem que os trabalhadores têm desprazer com seus trabalhos e, por isso, exigem recompensas externas. No caso dos trabalhadores cujo principal instrumento de trabalho é o conhecimento, essa hipótese não pode ser adequadamente utilizada pois, freqüentemente, eles gostam do que fazem. Esse tipo de trabalhador deriva recompensas intrínsecas (não-externas) por trabalhar com a ciência, afinal, eles escolheram as carreiras que abraçaram e se identificam como profissionais dessa ciência. A presença de fortes motivações intrínsecas enfraquece a vinculação entre a avaliação de desempenho e o sistema de recompensas.

Austin \& Larkey (2000) ressaltaram que, na presença de fortes recompensas intrínsecas, caso típico dos que têm o conhecimento como principal instrumento de trabalho, a tentativa de introduzir recompensas externas vinculadas à medição da produção pode, na 
realidade, acabar reduzindo a motivação intrínseca e, consequentemente, reduzir o poder estimulador do sistema de recompensas.

Tratemos, então, da característica de controllability, enfatizada por Moon \& Fitzgerald (1996). Um ponto a ser registrado é que Kaplan, em vários textos, sugere que o sistema de custeio denominado Activity Based Cost $(A B C)$ seja utilizado como complemento ao Balanced Scorecard. Tal procedimento, no entanto, não é o mais adequado para se obter a característica de controllability, acima referida.

Todo sistema de rateio implica em atribuir, ao gestor/produto, custos que não foram gerados por ele e sobre os quais não pode adotar ações corretivas. Ratear os custos estruturais é negar a existência de uma hierarquia de decisões na empresa. As decisões, na empresa, estão organizadas de acordo com os níveis de poderes e responsabilidades dos gestores mas as informações geradas pelos sistemas tradicionais, entre eles o $A B C$, não estão organizadas da mesma maneira, culpando o produto ou a atividade por ineficiências gerados em outras instâncias.

Seguir a orientação de Kaplan (1994-b), de utilizar o Balanced Scorecard associado ao $A B C$, resulta em não atender ao requisito de controllability, enfatizado por Moon \& Fitzgerald (1996), importante para a vinculação entre a avaliação de desempenho e a recompensa aos empregados.

\subsection{3 - CRÍTICAS INDEVIDAS}

A disseminação do Balanced Scorecard foi acompanhada pela compreensão equivocada e, consequentemente, surgiram muitas críticas indevidas. O objetivo aqui não é fazer uma listagem extensa dessas críticas mas tratar das que nos pareceram mais importantes, quais sejam: 1) uso de medidas genéricas; 2) ausência de tratamento da relação entre 
eficiência e eficácia, dos fatores de benchmarking, dos fatores incontroláveis e da ligação entre as medidas de desempenho qualitativo e de desempenho financeiro; 3) a rigidez do modelo; 4) considerações do ambiente externo à empresa serem limitadas ao nível dos clientes; e, 5) deficiência no tratamento dos empregados e da tecnologia da informação.

Udpa (1997) criticou o uso de medidas genéricas, a falta de orientação para os gestores selecionarem as medidas de desempenho e identificarem as variáveis chaves e fazerem as escolhas entre as alternativas conflitantes (trade-off).

Tal crítica expressa a reivindicação por uma "receita de bolo", a falta de percepção de que é impossível gerar uma receita que consiga contemplar a enorme diversidade de situações com que se defrontam as diferentes empresas, nos diferentes setores, nos diferentes países. O Balanced Scorecard não é uma metodologia de definição de estratégia mas, um conjunto de critérios, um guia, para a implementação e gestão de uma estratégia previamente definida.

Udpa (1997) criticou, ademais, o fato de que Kaplan \&Norton se preocuparam em enfatizar a necessidade de se considerar as relações de causa e efeito entre as medidas mas não explicitaram a ligação entre eficiência e eficácia.

Nada, nos textos de Kaplan \& Norton, sugere que o Balanced Scorecard prescinda do uso de um sistema de custo padrão ou de outros sistemas julgados necessários para uma eficiente obtenção da eficácia. Falta à crítica, a percepção de que, em última instância, o que liga a eficiência à eficácia são as relações de causa e efeito.

Udpa (1997) criticou, também, a falta de uma discussão mais aprofundada dos benchmarks, especialmente os relacionados com as atividades dos concorrentes.

A crítica expressa a falta de compreensão de que o Balanced Scorecard não é, nem pretende ser, um compêndio de gestão. As informações sobre os concorrentes devem ser 
vistas e revistas fora do escopo do Balanced Scorecard, nos momentos do estabelecimento e da revisão da estratégia.

Udpa (1997) criticou, ainda, a falta de uma discussão mais aprofundada do impacto de fatores incontroláveis.

O Balanced Scorecard é um instrumento para vincular a estratégia à operação, tendo dificuldades, portanto, para gerir fatores que, por definição, são incontroláveis. A consideração sobre os fatores incontroláveis deve ser feita na definição e na revisão da estratégia.

As atividades dos concorrentes e os fatores incontroláveis devem ser levados em conta nas proposições das relações de causa e efeito dos fatores críticos de sucesso e das perspectivas.

Cates (1997) criticou o Balanced Scorecard por não estabelecer formalmente a ligação entre as medidas não tradicionais e os resultados financeiros, não permitindo traduzir indicadores de desempenho qualitativo em sinais de qualidade financeira.

Essa crítica não procede pois a ligação formal é feita mediante os relacionamentos de causa e efeito entre os fatores críticos de sucesso. A estratégia é um conjunto de hipóteses sobre relacionamentos de causa e efeito entre variáveis. Esses relacionamentos de causa e efeito podem ser expressos por uma sequiência de afirmações do tipo "se-então". A organização, consequentemente, para definir sua estratégia e os objetivos de curto prazo dela decorrentes, faz uma série de suposições acerca desses relacionamentos. Quando o gestor, por exemplo, supõe que com um treinamento específico a um grupo de funcionários, vai-se aumentar as vendas de um determinado produto, com determinada margem, está-se 
estabelecendo uma ligação formal, embora não objetiva, entre um direcionador de desempenho qualitativo e um resultado financeiro.

Bontis \& Dragonetti \& Jacobsen \& Roos (1999) alegaram que as quatro perspectivas constituem um fator de rigidez do Balanced Scorecard. Registram que os autores do Balanced Scorecard mencionam a possibilidade de se expandir o número de perspectivas, caso existam ações críticas que suportem/justifiquem essa expansão. A expansão do número de perspectivas, sujeita à restrição de que só deve ser feita quando existirem ações críticas justificando-as, segundo Bontis et al. (1999), constitui uma "camisa-de-força" para o gestor, explicita uma rigidez do modelo.

O que os referidos autores estão chamando de rigidez é, na realidade, um requisito de coerência lógica do Balanced Scorecard. A restrição à expansão do número de perspectivas serve para evitar a proliferação, sem rigor, de perspectivas e de medidas, que retirariam a simplicidade, a concisão e a operacionalidade, do Balanced Scorecard. Além do mais, as quatro perspectivas constituem uma das contribuições de Kaplan \& Norton à literatura de contabilidade gerencial. Elas expressam uma particular concepção de como o resultado final é produzido pela empresa e, consequentemente, o encadeamento de decisões que conduzem ao cumprimento da estratégia.

Uma segunda crítica contida em Bontis et al. (1999) é que as considerações do ambiente externo à empresa são limitadas ao nível dos clientes mas as empresas interagem com os fornecedores, com os sindicatos, com a comunidade local e com os consumidores finais.

Nada impede que os fornecedores, os sindicatos e a comunidade local sejam incluídos na dimensão cliente. Incluí-los, ou não, é uma decisão relativa a cada empresa, em cada 
momento do tempo, em função dos fatores objetivos com que estiver se defrontando. Incluílos numa dimensão já existente, ao invés de criar uma nova dimensão, tem a vantagem de manter a simplicidade e a operacionalidade do Balanced Scorecard.

O fato de se ter destacado o cliente não impede a empresa de incorporar os outros agentes externos com os quais interage nessa mesma dimensão ou até nas dimensões que forem mais apropriadas. Se a empresa tiver que traçar objetivos estratégicos relacionados a qualquer um desses outros agentes que mereçam destaque, ela pode criar mais uma perspectiva. Kaplan \& Norton (1997), por exemplo, comentaram a possibilidade de se criar a perspectiva ambiental pois a cada dia aumenta o número e a importância das ações nesse campo.

O fundamental não é ter mais ou menos dimensões mas, a manutenção da objetividade na gestão da estratégia. O relevante é a atenção para as relações de causa e efeito direcionadoras de outras, até que o próximo efeito seja a própria estratégia. É essa atenção que vai permitir que, a partir da constatação do não atingimento de um particular objetivo de um determinado nível, se percorra a hierarquia procurando identificar qual ou quais determinantes falharam.

Uma terceira crítica contida em Bontis et al. (1999) é que o tratamento dos empregados, junto com tecnologia de informação, na perspectiva de Aprendizado e Crescimento, mostra que ambos são tratados como coisas pelo Balanced Scorecard. Tal tratamento mostra uma subestimação do desafio de se gerir pessoas e conhecimento. Além disso, a inovação é vista como um processo interno. Mais que isso, a inovação, que é o resultado do aprendizado humano e da ação, é considerada como um processo rotineiro, como algo que a organização pode fazer sem as pessoas ou pode fazer independentemente delas. $\mathrm{O}$ conhecimento é visto como algo físico, o que reforça o erro que vem sendo cometido por 
várias empresas, de acreditarem que, para se gerir conhecimento, é suficiente um sistema de tecnologia da informação.

O tratamento dos empregados em conjunto com a tecnologia da informação, pelo Balanced Scorecard, expressa a íntima vinculação entre eles, quando o objetivo é o aumento da produtividade/lucratividade necessárias ao cumprimento da missão da organização. Expressa uma visão de que a combinação dos dois gera uma sinergia fundamental para a gestão.

Nos primeiros artigos sobre o Balanced Scorecard (de 1992 à 1994), os autores trataram a inovação junto com o aprendizado, separadamente da perspectiva de processos internos. Nessa fase, a perspectiva de Inovação e Aprendizado era vista como o conjunto de objetivos que deveriam ser traçados quanto a inovações (em processos e em produtos) que promovesse o aumento da satisfação dos clientes e a eficiência dos processos internos, ou de forma mais genérica, que promovesse um melhoramento dos desempenhos nessas duas perspectivas, levando a um melhoramento do desempenho financeiro.

Em 1996, Kaplan \& Norton ${ }^{119}$ reformularam a apresentação do Balanced Scorecard, passando a tratar o processo interno em duas dimensões vitais as quais chamou de onda curta de criação de valor e onda longa de criação de valor. A onda curta de criação de valor se refere aos melhoramentos e controles das operações existentes. A onda longa de criação de valor se refere ao processo de inovação. A perspectiva de Aprendizado e Crescimento passa a refletir a infra estrutura que a organização precisa construir para gerar crescimento e melhoramento de longo prazo. Assim, os objetivos financeiros, os objetivos relacionados a clientes e os objetivos relacionados aos processos internos, irão revelar a lacuna entre as

119 Embora os novos termos e definições já tenham aparecidos no artigo de Kaplan \& Norton (1996-a), apenas em Kaplan \& Norton (1996-c) explicam a mudança. 
capacitações das pessoas, os sistemas e os procedimentos existentes e as necessárias para promover o cumprimento da estratégia.

A classificação da Inovação e dos Recursos Humanos no Balanced Scorecard não diz nada sobre a forma de geri-los. Apenas sugere uma organização dos objetivos a serem alcançados para realizar a estratégia definida. Vincular a produção de conhecimentos com a estratégia corporativa é uma tentativa de evitar investimentos em conhecimentos que não são necessários para a empresa no seu horizonte de médio e longo prazo. A produção de conhecimentos assim como outros objetivos, não pode se tornar um fim em si mesmo ${ }^{120}$.

O Balanced Scorecard não é um modelo geral de gestão. A sua preocupação é fazer com que a empresa não perca de vista a sua estratégia. A forma como cada empresa vai gerir o cumprimento dos objetivos não faz parte do escopo do Balanced Scorecard.

\section{3 - AMPLA DISSEMINAÇÃO E MODISMO}

A existência de um ambiente propício para o surgimento de novas idéias e a decodificação de temas complexos e sofisticados, arranjados em uma maneira simples e didática, apoiada pelas firmas de consultoria e por "pacotes" de soluções de informática, parecem explicar a ampla disseminação do Balanced Scorecard, o seu sucesso na academia e nas empresas.

Existem indicações de que essa disseminação foi exagerada e resultou numa vulgarização, num modismo, com o surgimento de críticas indevidas e a subestimação de problemas de implantação e de pontos fundamentais para a gestão mas que não são tratados diretamente pelo Balanced Scorecard.

${ }^{120}$ Como reforça Hiebeler (1996), é o conhecimento adquirido que deve ser gerido e não o processo de adquirir conhecimento, por si só. 
O presente capítulo levantou a hipótese de que esses dois pontos estão interligados, ou melhor, que a razão do sucesso é, também, a razão da vulgarização, apesar dos cuidados com que Kaplan \& Norton expõem seu trabalho. 


\section{CONCLUSÃO}

O Balanced Scorecard pode ser sumariado como um relatório único, contendo medidas de desempenho financeiro e não-financeiro nas quatro perspectivas de gestão (financeira, clientes, processos internos e aprendizado e crescimento) que indicam como a estratégia da empresa será cumprida. Seus autores afirmam que ele constitui-se num sistema de gestão estratégica mas, seu foco não é a estratégia em si e sim, o desdobramento dessa estratégia. Ele, portanto, não deve ser classificado como um sistema de gestão estratégica, como o fizeram Kaplan \& Norton, sendo mais adequado classificá-lo como um sistema de suporte à decisão.

A analogia entre um painel de instrumentos e um simulador de vôo é adequada para expressar a diferença entre o Balanced Scorecard e o Tableau de Bord, como o fizeram Kaplan \& Norton mas, não pelo motivo por eles apresentado, uma vez que os relacionamentos de causa e efeito estão presentes em ambas as técnicas. A disposição dos relacionamentos de causa e efeito, entre a estratégia e a operação e entre as quatro perspectivas que representam as dimensões clássicas da gestão (produzir, vender e suporte administrativo para produzir e vender), num relatório único, é que faz com que o Balanced Scorecard deixe de ser um simples painel de instrumentos e se constitua num simulador de vôo. O Balanced Scorecard permite, a cada instante, enxergar os aspectos críticos, da empresa como um todo, para o cumprimento da estratégia.

O Balanced Scorecard não traz qualquer conceito novo, nunca antes tratado na literatura de contabilidade gerencial, mas repensa temas antigos, chamando a atenção para pontos que estavam esquecidos ou mal compreendidos, mostrando a vinculação entre pontos vitais que não estavam claramente articulados. Ele mostra, assim, como esses conhecimentos 
estabelecidos podem ser aplicados aos tempos modernos, para atender às exigências impostas pelo ambiente mais competitivo para as empresas e, consequentemente, aumenta a compreensão do tema "vinculação entre estratégia e operação".

O Balanced Scorecard, atende ao critério Cardoso (1980)-Iudícibus (1996) e, pode ser considerado uma contribuição original à literatura de contabilidade gerencial e não um simples plágio. Allen (1999) e Malcolm (1999) têm uma concepção restrita de originalidade teórica, simplesmente tratar de pontos nunca antes abordados, e, por isso, sugeriram que o Balanced Scorecard era um plágio.

O Balanced Scorecard teve sua divulgação ampliada em razão da insatisfação com os instrumentos tradicionais de avaliação de desempenho, de promover a decodificação de temas complexos, e de ter despertado o interesse das firmas de software e das firmas de consultoria. Essa ampla divulgação, no entanto, transformou-se num modismo, apesar disso ser incompatível com os cuidados com que Kaplan \&Norton apresentam seus trabalhos.

Os fatores que explicam a ampla divulgação também estão presentes na explicação para o modismo. A lista deve incluir, também, a subestimação das dificuldades para se implementar o Balanced Scorecard, para se estabelecer um padrão adequado de medidas e para vincular o sistema de recompensas àquele. Os problemas apontados por Skinner (1969) e por Allen (1999), relativos ao ensino de contabilidade, somados à falta de uma teoria geral, apontada por John Kay ${ }^{121}$, em última instância, explicam porque a ampla disseminação do trabalho de Kaplan \& Norton transforma-se num modismo.

121 Palestra de Abertura do Second International Conference on Performance Measurement, University of Cambridge, UK, 19-21 July 2000. 


\section{REFERÊNCIAS BIBLIOGRÁFICAS}

ABERNATHY, William (1997). Balanced scorecards make teamwork a reality. Journal for Quality \& Participation, Cincinnati, v. 20, Iss. 5, pp.58-59, Nov./Dec. 1997.

ALAN, Roberts (1995). Management accounting in France. Management Accounting, London, v. 73, Mar 1995.

ALLEN, David (1997). Managerial megatrends: the opportunity. Management Accounting, London, v. 75, p.48, Apr 1997.

ALLEN, David (1999). Scorekeepers ... or Scorers? Management Accounting, London, v. 77, p. 18, May 1999.

ANDREWS, K. R. (1971). The concept of corporate strategy. New York: Dow Jones-Irwin, 1971.

ANSOFF, H. I. (1965). Corporate Strategy. New York: McGraw-Hill, 1965.

ASBRAND, Deborah (1997). Is datamining ready for the masses? Datamation, Nov. 1997. Disponível em < http://datamation.com/PlugIn/workbench/dwhouse >. Acesso em 18/05/98.

AUSTIN, Robert D. \& LARKEY, Patrick D. (2000). Performance-based incentives in knowledge work: are agency models relevant? International Journal of Business Performance Management, Centre for Business Performance, Cranfield School of Management, UK, v. 2, $\mathrm{n}^{\text {os. }} 1,2$ e 3, pp. 56-71, 2000. 
AXSON, David A. J. (1999) The fastest route to right answers. Strategy \& Leadership, Chicago, v. 27, pp.6-10, May/Jun. 1999.

BANKS, Robert L. \& WHEELWRIGHT, Steven C. (1979) Operations vs. strategy: trading tomorrow for today. Harvard Business Review, Boston, v. 57, Iss. 3, pp.112-120, May/Jun. 1979.

BEISCHEL, Mark E. \& SMITH, K. Richard (1991). Linking the shop floor to the top floor. Management Accounting, New York, pp. 25-29, October 1991.

BIRCHARD, Bill (1995). Making it count - how innovative companies really use the new metrics. CFO, Boston, v. 11, Iss. 10, pp.42-51, October 1995.

BIRCHARD, Bill (1996). Where performance measures fail. CFO, Boston, v. 12, p. 36, Oct 1996.

BONTIS, Nick \& DRAGONETTI, Nicola C \& JACOBSEN, Kristine \& ROOS, Goran (1999) The knowledge toolbox: a review of the tools available to measure and manage intangible resources. European Management Journal, Scottish Business School: Pergamon, v.17, n 4, pp. 391-402, Aug 1999.

BOOTH, Rupert (1996a). Accountants do it by proxy. Management Accounting, London, v. 74, p.48, May 1996.

BOOTH, Rupert (1996b). The blue sky and the brown field. Management Accounting, London, v. 74, p.16, Sep. 1996.

BOURNE, Mike \& NEELY, Andy (1998). Why do performance measurement initiatives succeed and fail? In: The First International Conference on Performance Measurement, 
1998, Centre for Business Performance, University of Cambridge, Cambridge: Fieldfare Publications Ltd, pp. 165-172.

BRINDLEY, William A \& BEAR, Michael J. (1997). The Citibank Private Bank's portfolio balancing act. Journal of Business Strategy, Boston, v. 18, Iss. 4, pp. 12-17, Jul./Aug. 1997.

CARDOSO, Fernando Henrique (1980). A dependência revisitada. In: As idéias e seu lugar: ensaios sobre as teorias do desenvolvimento. Caderno Cebrap $\mathrm{n}^{\mathrm{o}}$ 33. Petrópolis: Vozes/Cebrap, p.57, 1980.

CARDOSO, Fernando H. \& FALETTO, Enzo (1970). Dependência e desenvolvimento na América Latina: ensaio de interpretação sociológica. Rio de Janeiro: Zahar Editores, 1970.

CATES, David C. (1997). Performance measurement: welcome to the revolution. Banking Strategies, Chicago, v. 73, pp.51-56, May-Jun 1997.

CHANDLER JR, Alfred D (1962). Strategy and structure. Massachusetts, Cambridge: The M.I.T. Press, 1962.

CHESLEY, Julie A. \& WENGER , Mike S. (1999). Transforming an organization: using models to foster a strategic conversation. California Management Review, Berkeley, v. 41, pp.54-73, Spring 1999.

CHOW, Chee W. \& HADDAD, Kamal M. \& WILLIAMSON, James E. (1997). Applying the balanced scorecard to small companies. Management Accounting, New York, Aug 1997, pp. 21-27. 
CITY OF CHARLOTTE \& MECKLENBURG (1997). Charlotte's Balanced Scorecard. Disponível em: <http://www.ci.charlotte.nc.us>. Acesso em 31/05/00.

CLARKE, Peter. (1997). The balanced scorecard. Accountancy Ireland, Dublin, v. 29, p.2526, Jun 1997.

COLlINS, Jim \& PORRAS, Jerry (1994). Built to last: successful habits of visionary companies. [] HarperCollins, 1994.

COOPER, Robin \& KAPLAN, Robert S. et al. (1992). Implementing activity based management: moving from analysis to action. Montvale: IMA, 1992.

CROSS, K. F. \& LYNCH, R. L. (1988/9). The Smart way to sustain and define success. National Productivity Review, v. 8, nº 1, pp. 23-33, 1998/1999.

CUSTÓDIO, Isaías (1981). Avaliação de sistemas de informação. São Paulo, 1981. Dissertação (Mestrado) - FEA-USP.

DALY, Dennis C. (1996). Performance measurement and management. Management Accounting, New York, v. 78, pp.65-66, Sep. 1996.

DATTA, Hindol (1997). The Balanced Scorecard. Management Accounting, New York, v., p.72, Mar. 1997.

DEVERS, Kelly J. \& SHORTELL, Stephen M. \& GILLIES, Robin R. \& ANDERSON, David A. et al. (1994). Implementing organized delivery systems: an integration scorecard. Health Care Management Review, Gaithersburg, v. 19, p.7, Summer 1994.

DRYSDALE, Louise (1996). Lawless in Chicago. Management Accounting, London, v. 74, p. 56-57, Oct. 1996. 
ECCLES, Robert G. (1991). The performance measurement manifesto. Harvard Business Review, Boston, v. 69, Iss. 1, pp.131-137, Jan./Feb. 1991.

ECCLES, Robert G. \& PYBURN, Philip J. (1992). Creating a comprehensive system to measure performance. Management Accounting, New York, v. 74, pp. 41- 44, Oct. 1992.

EPSTEIN, Marc J. \& MANZONI, Jean-François (1997). The Balanced Scorecard and Tableau de Bord - translating strategy into action. Management Accounting, New York, Aug. 1997, pp.28-36.

EPSTEIN, Marc J. \& MANZONI, Jean-François (1998). Implementing corporate strategy: from Tableau de Bord to Balanced Scorecard. European Management Journal, Scottish Business School: Pergamon, v. 16, nº 2, pp.190-203, Apr. 1998.

FITZGERALD, L. \& JOHNSTON, R. \& BRIGNALL, T. J. \& SILVESTRO, R. \& VOSS, C (1991). Performance measurement in service businesses. The Chartered Institute of Management Accounting, London, 1991.

FRIGO, Mark L. \& KRUMWIEDE, Kip R. (2000). The balanced scorecard. Strategic Finance, Montvale, v. 81, pp. 50-54, Jan. 2000.

GRANT, Robert M. \& NEUPERT, Kent E. (1999). Cases in Contemporary Strategy Analysis. $2^{\text {nd. }}$ ed.. Oxford: Blackwell Business, 1999.

GRAY, Jack \& PESQUEUX, Yvon (1993). Evolutions actuelles des systèmes de tableau de bord - comparaison des pratiques de quelques multinationales américaines et françaises. Revue Française de Comptabilité, [s.1.], nº 242, pp. 61-70, fev. 1993.

GROSSMAN, Robert J. (2000). Measuring up. HR Magazine, Alexandria, v. 45, pp. 28-35, Jan. 2000. 
HANSON, Jim \& TOWLE, George (2000). The balanced scorecard: not just another fad. Credit Union Executive Journal, Madison, v. 40, pp. 12-16, Jan./Feb. 2000.

HATCH, Eric K. (2000). Cowboys and settlers: is your organization big enough for the both of them? The Journal for Quality and Participation, Cincinnati, v. 23, pp.20-23, Jan./Feb. 2000.

HAYES, Robert H. \& GARVIN, David A. (1982). Managing as if tomorrow mattered. Harvard Business Review, Boston, v. 60, Iss. 3, pp.70-79, May/Jun. 1982.

HENDERSON, John C. \& VENKATRAMAN, N. (1992). Strategic Alignment: a model for organizational transformation through information technology. In: KOCHAN, Thomas A. \& USEEM, M. Transforming Organizations, Oxford University Press, New York, 1992, chap.7, pp.97-117.

HIEBELER, Robert J. (1996). Benchmarking: knowledge management. Strategy \& Leadership, Chicago, v. 24, p.22, Mar./Apr. 1996.

HOLT, Stannie (1998). ERP vendors help users keep score. InfoWorld, Framingham, v. 20, p.12, Nov.1998.

HORNGREN, Charles T. \& HARRISON JR, Walter T. \& ROBINSON, Michael A. (1996). Accounting. 3rd Edition. New Jersey: Prentice Hall, 1996.

HUBBARD, Gerald M. (1992). Keys to creating performance measures. Facilities Design \& Management, New York, v. 11, Iss. 5, pp. 66-68, May 1992.

INGALLS JR, Theodore (1999). Using scorecards to measure safety performance. Professional Safety, Park Ridge, v. 44, pp. 23-28, December 1999. 
IUDÍCIBUS, Sérgio de (1996). A gestão estratégica de custos e sua interface com contabilidade gerencial e teoria da contabilidade: análise sucinta. Revista Paulista de Contabilidade, Out. 1996, p. 20-21.

IUDÍCIBUS, Sérgio de (1999). Sistemas de informação gerencial: novos (e antigos) paradigmas. Revista da ANEFAC, ano 9, nº 68, p. 10-13, 1999.

JAMES, Wendy \& HOQUE, Zahirul (1997). Balancing the scorecard: beyond the bottom line. Australian Accountant, Nov. 1997, pp.46-47.

JONES, Stewart \& SHARMA, Robert (1999). Multi-dimensional management: a framework for action. Australian CPA, Melbourne, v.69, pp.48-50, May 1999.

JOHNSON, H. Thomas \& KAPLAN, Robert S. (1987). Relevance lost - the rise and fall of management accounting. Boston: Harvard Business School Press, 1987.

KAPLAN, Robert S. (1983). Measuring manufacturing performance: a new challenge for managerial accounting research. The Accounting Review, Sarasota, v. LVIII. n ${ }^{\circ}$, pp. 686705, Oct. 1983.

KAPLAN, Robert S. (1994a). Devising a Balanced Scorecard matched to business strategy. Planning Review, [s.1.], Sep./Oct. 1994, pp. 15-48.

KAPLAN, Robert S. (1994b). Management accounting (1984-1994): development of new practice and theory. Management Accounting Research, CIMA, UK, v. 5, n ${ }^{\circ}$ 3/4, pp. 247260, Sep./Dec. 1994.

KAPLAN, Robert S. \& NORTON, David P. (1992). The Balanced Scorecard - measures that drive performance. Harvard Business Review, Boston, v. 70, Iss. 1, pp. 71-79, Jan./Feb. 1992. 
KAPLAN, Robert S. \& NORTON, David P. (1993). Putting the Balanced Scorecard to work. Harvard Business Review, Boston, v. 71, Iss. 5, pp. 134-147, Sep./Oct. 1993.

KAPLAN, Robert S. \& NORTON, David P. (1996a). Using the Balanced Scorecard as a strategic management system. Harvard Business Review, Boston, v. 74, Iss. 1, pp. 75-85, Jan./Feb. 1996.

KAPLAN, Robert S. \& NORTON, David P. (1996b). The balanced scorecard is more than just a new measurement system. Harvard Business Review, Boston, v. 74, Iss. 3, pp. 7585, May/Jun. 1996.

KAPLAN, Robert S. \& NORTON, David P. (1996c). Linking the Balanced Scorecard to strategy. California Management Review, Berkeley, v.39, nº 1, pp. 53-79, Fall 1996.

KAPLAN, Robert S. \& NORTON, David P. (1996d). Strategic learning \& the Balanced Scorecard. Strategy \& Leadership, Chicago, v. 24, Iss. 5, pp. 18-24, Sep./Oct. 1996.

KAPLAN, Robert S. \& NORTON, David P. (1996e). The balanced scorecard. Boston: Harvard Business School Press, Sep 1996.

KAPLAN, Robert S. \& NORTON, David P. (1996f). Knowing the score. Financial Executive, Morristown, v. 12, Iss.6, pp.30-33, Nov./Dec. 1996.

KAPLAN, Robert S. \& NORTON, David P. (1997). A estratégia em ação: balanced scorecard. Rio de Janeiro: Campus, 1997.

KAPLAN, Robert S. \& NORTON, David P. (2001). The strategy-focused organization: how balanced scorecard companies thrive in the new business environment. Massachusetts: Harvard Business School Press, Jan. 2001. 
KEEGAN, D. P. \& EILER, R. G. \& JONES, C. R. (1989). Are your performance measures obsolete? Management Accounting, Jun 1989, pp. 45 a 50

KEEN, Peter G. W. \& MORTON, Michael S. Scott (1978). Decision support systems - an organizational perspective. Massachussetts: Addison Wesley, 1978.

KERR, Steven (1975). On the folly of rewarding A, while hoping for B. Academy of Management Journal, Mississipi State, v. 18, n 4, pp. 769-783, Dec. 1975.

KURTZMAN, Joel (1997). Is your company off course? Now you can find out why. Fortune, New York, v. 135, pp. 128 a 130, Feb. 1997.

LEBAS, Michel (1994). Managerial accounting in France - overview of past tradition and current practice. The European Accounting Review, [s.1.], 3:3, pp. 471-487, 1994.

LIGHT, David A. (1998). Performance measurement - Investor's Balanced Scorecard. Harvard Business Review, Boston, v. 76, Iss. 6, pp. 17-20, Nov./Dec. 1998.

LUKKA, Kari \& SHIELDS, Michael (1999). Innovations in management accounting focus. Management Accounting, London, v. 77, pp. 33-34, Mar. 1999.

MALCOLM, Ian (1999). Scorekeepers or scorers. Management Accounting, London, v. 77, Jul./Aug. 1999, Letters to the Editor, p.12.

MALO, Jean-Louis (2000). Tableaux de bord. Encyclopédie de la Comptabilité, du Contrôle et de l'Audit. Economica, 2000, article 84, p. 1133-1144.

MARCOVITCH, Jacques (1978). Interação da instituição de pesquisa industrial com seu ambiente e suas aplicações na eficácia organizacional. São Paulo, 1978. Tese (Livre Docência) - FEA-USP.

MARTINS, Eliseu (1996). Contabilidade de custos. $5^{\text {a }}$ edição. São Paulo: Atlas, 1996. 
MARTINS, Eliseu. (1998). Os desafios da controladoria e contabilidade estratégica. Revista da ANEFAC, ano 8, nº 61, p.8, 1998.

MARTINS, Gilberto de Andrade (1994). Manual para elaboração de monografias e dissertações. 2a . ed. São Paulo: Atlas, 1994.

MAXIMiAnO, Antonio Cesar Amaru (1995). Introdução a administração. $4^{\mathrm{a}}$ edição. São Paulo: Atlas, 1995.

MCCUNN, Paul (1998). The eleventh commandment. Management Accounting, London, Dec. 1998, pp.34-36.

MCKINNON, Sharon M. \& BRUNS JR, William J. (1992). The Information mosaic: how managers use information. Boston: Harvard Business School Press, 1992.

MENDONZA, Carla \& ZRIHEN, Robert (1999). Le tableau de bord: en V.O. ou en version américaine? - comparaison entre le tableau de bord et le Balanced Scorecard. Revue Française de Comptabilité, n ${ }^{0}$ 309, pp.60-66, mars 1999.

MILLAR, Glen (1999). European finance function summit transforming the finance function into a value-added business partner. Management Accounting, London, v. 77, p.34-35, Mar. 1999.

MINTZBERG, Henry (1994). The rise and fall of strategic planning: reconceinving roles for planning, plans, planners. Ontario: The Free Press, 1994.

MOON, Philip \& FITZGERALD, Lin (1996). The Role of the Performance Measurement System. Management Accounting Research, CIMA, UK, v. 7, $\mathrm{n}^{\mathrm{o}}$ 4, pp. 431-457, Dec. 1996. 
MOORAJ, Stella \& OYON, Daniel \& HOSTETTLER, Didier (1999). The Balanced Scorecard: a necessary good or an unnecessary evil? European Management Journal, Scottish Business School, Pergamon, v. 17, nº 5, pp. 481-491, Oct 1999.

MURPHY, Mary E. (1963). Managerial Accounting. New York: D. Van Nostrand Company, Inc., 1963.

NAKAGAWA, Masayuki (1987). Estudo de alguns aspectos de controladoria que contribuem para a eficácia gerencial. São Paulo, 1987. Tese (Doutoramento) - FEA-USP.

NAKAGAWA, Masayuki (1996). Gestão estratégica de custos. São Paulo: Atlas, 1996.

NEELY, Andy \& AUSTIN Rob (2000). Measuring operations performance: past, present and future. In: Second International Conference on Performance Measurement, University of Cambridge, Cambridge, UK, July 2000. Performance Measurement-Past, Present and Future, Edited by Andy Neely, Cranfield, Centre for Business Performance, 2000.

NEWING, Rod (1995). Wake up to the balanced scorecard! Management Accounting, London, v. 73, pp. 22-23, Mar. 1995.

OHMAE, Kenichi (1982). The mind of the strategist - the art of Japanese business. [s.1.]: McGraw-Hill, 1982.

OHMAE, Kenichi (1985). O estrategista em ação - a arte japonesa de negociar. São Paulo: Livraria Pioneira, 1985.

OLIVEIRA, Djalma de P. Rebouças de (1986). Uma contribuição ao estudo dos instrumentos facilitadores da operacionalização do planejamento estratégico nas organizações. São Paulo, 1986. Tese (Doutoramento) - FEA-USP. 
OTLEY, D. (1987). Accounting control and organisational behaviour. London: Heinermann, 1987.

PEAL, C. Wayne (1999). Strategies for success. Government Executive, Washington, v. 31, pp.68-74, Jul. 1999.

PLANNING processes 'overlong and inefficient'(1998). Management Accounting, London, v. 76, p.10, Nov 1998.

PORTER, Michael E. (1985). Competitive Advantage. New York: Macmillian, 1985.

PORTER, Michael E. (1991). Estratégia Competitiva: técnicas para análise de indústrias e da concorrência. Rio de Janeiro: Campus, 1991.

PORTER, Michael E. (1992). Vantagem Competitiva: criando e sustentando um desempenho superior. Rio de Janeiro: Campus, 1992.

RICCIO, Edson Luiz (1989). Uma contribuição ao estudo da contabilidade como sistema de informação. São Paulo, 1989. Tese (Doutoramento) - FEA-USP.

ROCHA, Welington (1999). Contribuição ao estudo de um modelo conceitual de sistema de informação de gestão estratégica. São Paulo, 1999. Tese (Doutoramento) - FEA-USP.

SHANK, John K. \& GOVINDARAJAN, Vijay (1995). Gestão estratégica de custos - a nova ferramenta para a vantagem competitiva. Rio de Janeiro: Campus, 1995.

SKINNER, Wickham (1969). Manufacturing - missing link in corporate strategy. Harvard Business Review, Boston, May/Jun. 1969, pp.136-145.

SOARES, Paulo de Tarso P.L. (1996). Globalização ou Imperialismo? Revista Crítica Marxista, São Paulo, v. 1, no 3, p. 146-148, 1996. 
SURVEYER, Jacques (1998). Microsoft and OLAP: sudden impact. Informationweek, Manhasset, Iss. 700, pp. 313-322, Sep. 14, 1998.

STALK, George \& WEBER, A. M. (1993). Japan's dark side of time. Harvard Business Review, Boston, v. 71, Iss. 4, pp. 93-102, Jul./Aug. 1993.

STEINBERG, Allen (1996). Assessing the future of cash balance plans - using a balanced scorecard approach. Benefits Quarterly, Brookfield, v. 12, Iss. 3, pp. 51-57, Third Quarter 1996.

STRENGER, Ellen Weisman (1997). Dashboards, Smashboards. Trustee, Chicago, v. 50, Iss. 4, p. 9, Apr. 1997.

THE, Lee (1995). OLAP answers tough business questions. Datamation, May 1995. Disponível em: < http://datamation.com/PlugIn/workbench/olap>. Acesso em 18/05/98.

THE BMA GROUP PTY LTD (1999). Balanced Scorecard. Disponível em <http:// homepages.tig.com.au/ bma/perfimpr.html>. Acesso em 31/05/00.

TONCHIA, Stefano (2000). Linking performance measurement system to strategic and organizational choices. International Journal of Business Performance Management, Centre for Business Performance, Cranfield School of Management, UK, v. 2, $n^{\circ} 1 / 2 / 3$, pp. 15-29, 2000.

UDPA, Suneel C. (1997). The Balanced Scorecard. The Accounting Review, Sarasota, v. 72, Iss. 1, pp. 178-179, Jan.1997.

VAN DE VLIET, Anita (1997). The new balancing act. Management Today, London, Jul. 1997, pp.78-80. 
VITALE, Michael R. \& MAVRINAC, Sarah C. (1995). How effective is your performance measurement system? Management Accounting, New York, v. 77, p.43, Aug. 1995.

VITALE, Michael R. \& MAVRINAC, Sarah C. \& HAUSER, Mark (1994). Case Study DHC: the chemical division's Balanced Scorecard. Planning Review, [s.1.], pp.17-45, Jul./Aug. 1994.

VOKURKA, Robert \& FLIEDNER, Gene (1995). Measuring operating performance: a specific case study. Production and Inventory Management Journal, Alexandria, v. 36, Iss.1, pp. 38-43, First Quarter, 1995.

YAVITZ, Boris \& NEWMAN, William H (1982). Strategy in action - the execution, politics and payoff of business planning. New York: The Free Press, 1982.

YOSHIKAWA, Dorivaldo Mikio (1997). Contribuição ao estudo da utilização de indicadores estratégicos de gerenciamento - "scorecards" - pela controladoria em instituições financeiras. São Paulo, 1997. Dissertação (Mestrado) - FEA/USP.

WALTON, Richard E. (1998). Tecnologia da informação - o uso da TI pelas empresas que obtém vantagem competitiva. São Paulo: Atlas, 1998.

WILLYERD, Karie A. (1997). Balancing your evaluation act. Training, Minneapolis, v. 34, Iss.3, p.52-58, Mar. 1997. 


\section{ÍNDICE}

Abernathy, William. (1997), 2.

Alan, Roberts (1995), 92.

Allen, David (1997), 100.

Allen, David (1999), 3, 4, 68, 69, 70, 82, 97, 98, 104, 136.

Andrews, K. R. (1971), 47.

Ansoff, H. I. (1965), 47.

Asbrand, Deborah (1997), 109.

Austin, Robert D. \& Larkey, Patrick D. (2000), 123, 124, 125, 126.

Axson, David A. J. (1999), 111.

Banks, Robert L. \& Wheelwright, Steven C. (1979), 50, 75, 102.

Beischel, Mark E. \& Smith, K. Richard (1991), 50, 75, 76, 77, 78, 79, 80, 103.

Birchard, Bill (1995), 2.

Birchard, Bill (1996), 113, 114.

Bontis, Nick \& Dragonetti, Nicola C \& Jacobsen, Kristine \& Roos, Goran (1999), 116, 130, 131.

Booth, Rupert (1996a), 105, 106.

Booth, Rupert (1996b), 1.

Bourne, Mike \& Neely, Andy (1998), 112.

Brindley, William A \& Bear, Michael J. (1997), 2.

Cardoso, Fernando Henrique (1980), 4, 5, 6, 70, 71, 136.

Cardoso, Fernando H. \& Faletto, Enzo (1970), 4, 70.

Cates, David C. (1997), 129. 
Chandler Jr, Alfred D (1962), 46.

Chesley, Julie A. \& Wenger, Mike S. (1999), 2.

Chow, Chee W. \& Haddad, Kamal M. \& Williamson, James E. (1997), 103.

City of Charlotte \& Mecklenburg (1997), 2.

Clarke, Peter (1997), 1.

Collins, Jim \& Porras, Jerry (1994), 90.

Cooper, Robin \& Kaplan, Robert S. et al. (1992), 10, 109.

Cross, K. F. \& Lynch, R. L. (1988/9), 80.

Custódio, Isaías (1981), 48.

Daly, Dennis C. (1996), 1, 2.

Datta, Hindol (1997), 1.

Devers, Kelly J. \& Shortell, Stephen M. \& Gillies, Robin R. \& Anderson, David A. et al. (1994), 1.

Drysdale, Louise (1996), 1.

Eccles, Robert G. (1991), 95.

Eccles, Robert G. \& Pyburn, Philip J. (1992), 81, 103, 105.

Epstein, Marc J. \& Manzoni, Jean-François (1997), 87, 88, 89, 92, 95, 96.

Epstein, Marc J. \& Manzoni, Jean-François (1998), 87, 88, 89, 92, 95.

Fitzgerald, L. \& Johnston, R. \& Brignall, T. J. \& Silvestro, R. \& Voss, C (1991), 79.

Frigo, Mark L. \& Krumwiede, Kip R. (2000), 1.

Grant, Robert M. \& Neupert, Kent E. (1999), 105.

Gray, Jack \& Pesqueux, Yvon (1993), 91.

Grossman, Robert J. (2000), 1.

Hanson, Jim \& Towle, George (2000), 1. 
Hatch, Eric K. (2000), 112.

Hayes, Robert H. \& Garvin, David A. (1982), 50, 75, 103.

Henderson, John C. \& Venkatraman, N. (1992), 50.

Hiebeler, Robert J. (1996), 1, 133.

Holt, Stannie (1998), 108.

Horngren, Charles T. \& Harrison Jr, Walter T. \& Robinson, Michael A. (1996), 47, 50.

Hubbard, Gerald M. (1992), 81.

Ingalls Jr, Theodore (1999), 1.

Iudícibus, Sérgio de (1996), 5, 6, 49, 71, 136.

Iudícibus, Sérgio de (1999), 46, 119.

James, Wendy \& Hoque, Zahirul (1997), 1.

Jones, Stewart \& Sharma, Robert (1999), 1.

Johnson, H. Thomas \& Kaplan, Robert S. (1987), 9, 10.

Kaplan, Robert S. (1983), 7, 8, 9, 13, 14, 75, 98, 99.

Kaplan, Robert S. (1994a), 12, 15, 97.

Kaplan, Robert S. (1994b), 12, 68, 94, 107, 127.

Kaplan, Robert S. \& Norton, David P. (1992), 1, 10, 11, 15, 20, 22, 33, 34, 37, 50, 75, 97, 104.

Kaplan, Robert S. \& Norton, David P. (1993), 11, 15, 27, 29, 77.

Kaplan, Robert S. \& Norton, David P. (1996a), 1, 12, 14, 20, 21, 22, 24, 26, 30, 32, 44, 97, $104,122,132$.

Kaplan, Robert S. \& Norton, David P. (1996b), 14.

Kaplan, Robert S. \& Norton, David P. (1996c), 15, 18, 19, 29, 30, 31, 32, 33, 34, 36, 37, 40, $42,43,53,132$. 
Kaplan, Robert S. \& Norton, David P. (1996d), 16, 17.

Kaplan, Robert S. \& Norton, David P. (1996e), 1.

Kaplan, Robert S. \& Norton, David P. (1996f), 24, 60.

Kaplan, Robert S. \& Norton, David P. (1997), 20, 24, 34, 37, 45, 91, 92, 97, 122, 131.

Kaplan, Robert S. \& Norton, David P. (2001), 1, 12, 20, 21, 22, 24, 27, 28, 97, 122.

Keegan, D. P. \& Eiler, R. G. \& Jones, C. R. (1989), 76, 103.

Keen, Peter G. W. \& Morton, Michael S. Scott (1978), 55, 118.

Kerr, Steven (1975), 124, 125.

Kurtzman, Joel (1997), 110.

Lebas, Michel (1994), 83.

Light, David A. (1998), 1.

Lukka, Kari \& Shields, Michael (1999), 1.

Malcolm, Ian (1999), 4, 70, 97, 98, 136.

Malo, Jean-Louis (2000), 84, 95.

Marcovitch, Jacques (1978), 47.

Martins, Eliseu (1996), 119.

Martins, Eliseu. (1998), 47.

Martins, Gilberto de Andrade (1994), 5.

Maximiano, Antonio Cesar Amaru (1995), 47.

McCunn, Paul (1998), 110, 114, 116.

McKinnon, Sharon M. \& Bruns JR, William J. (1992), 103.

Mendonza, Carla \& Zrihen, Robert (1999), 88, 89, 90, 96.

Millar, Glen (1999), 1.

Mintzberg, Henry (1994), 47. 
Moon, Philip \& Fitzgerald, Lin (1996), 121, 122, 123, 127.

Mooraj, Stella \& Oyon, Daniel \& Hostettler, Didier (1999), 116.

Murphy, Mary E. (1963), 51, 78.

Nakagawa, Masayuki (1987), 49.

Nakagawa, Masayuki (1996), 51.

Neely, Andy \& Austin, Rob (2000), 61.

Newing, Rod (1995), 1.

Ohmae, Kenichi (1982), 50, 103.

Ohmae, Kenichi (1985), 47, 48, 77.

Oliveira, Djalma de P. Rebouças de (1986), 48.

Otley, D. (1987), 120, 121.

Peal, C. Wayne (1999), 104.

Planning processes 'overlong and inefficient'(1998), 111.

Porter, Michael E. (1985), 50, 73, 75, 79, 103.

Porter, Michael E. (1991), 48.

Porter, Michael E. (1992), 51.

Riccio, Edson Luiz (1989), 49, 116, 118, 119, 120.

Rocha, Welington (1999), 48, 53.

Shank, John K. \& Govindarajan, Vijay (1995), 46, 48, 49, 50, 51.

Skinner, Wickham (1969), 50, 72, 74, 76, 77, 78, 80, 96, 98, 99, 102, 106, 136.

Soares, Paulo de Tarso P.L. (1996), 71.

Surveyer, Jacques (1998), 108.

Stalk, George \& Weber, A. M. (1993), 103.

Steinberg, Allen (1996), 1. 
Strenger, Ellen Weisman (1997), 86, 89.

The, Lee (1995), 109.

The BMA Group Pty Ltd (1999), 1.

Tonchia, Stefano (2000), 52.

Udpa, Suneel C. (1997), 128, 129.

Van de Vliet, Anita (1997), 2, 105.

Vitale, Michael R. \& Mavrinac, Sarah C. (1995), 103.

Vitale, Michael R. \& Mavrinac, Sarah C. \& Hauser, Mark (1994), 2.

Vokurka, Robert \& Fliedner, Gene (1995), 2.

Yavitz, Boris \& Newman, William H (1982), 47, 50, 75, 103.

Yoshikawa, Dorivaldo Mikio (1997), 64.

Walton, Richard E. (1998), 50.

Willyerd, Karie A. (1997), 95. 